\title{
A new late Miocene (Tortonian) flora from Gavdos Island in southernmost Greece evaluated in the context of vegetation and climate in the Eastern Mediterranean
}

\author{
Dimitra Mantzouka, Zlatko Kvaček, Vasilis Teodoridis, Torsten Utescher, \\ Nicolaos Tsaparas, and Vasileios Karakitsios
}

With 8 figures, 3 tables and 2 appendices

\begin{abstract}
A new late Miocene (Tortonian) leaf flora has recently been recovered in the southernmost part of Europe on the island of Gavdos, Greece. So far, three conifers (Tetraclinis salicornioides, Taxodium dubium and Pinus sp.) and 27 fossil species/morphotypes of angiosperms have been recognized. Among them, some represent subtropical, partly evergreen woody elements (e.g. Daphnogene sp., Laurophyllum sp., Myrica lignitum), some others (e.g., ?Sassafras, Fagus gussonii, Ulmus, Acer angustilobum, Populus populina, Ailanthus pythii, Paliurus tiliifolius, several legumes) belong to deciduous shrubs or trees. The number of the determined angiosperms is sufficient for using statistical techniques to estimate palaeoclimate (LMA, CLAMP, CA) and to reconstruct the palaeovegetation (phytosociological approach, IPR-vegetation analysis).The Gavdos flora is based on leaf impressions and allows correlations with other Greek floras of almost the same age, namely from Crete - Vrysses (latest Tortonian to Messinian, ca. 7.5-6.0 Ma), Makrilia (late Tortonian, ca. 8.6-7.7 $\mathrm{Ma}$ ) and Pitsidia, Messara Basin (early Tortonian, ca. 10.5 Ma), while that from Vegora, Macedonia (Messinian, ca. 7-6 Ma) may document further trends in the late Miocene.
\end{abstract}

Key words: Leaf flora, palaeovegetation, palaeoclimate, late Miocene, Mediterranean, Greece.

\section{Introduction}

While climate evolution during the late Miocene and spatial gradients have been intensely studied for the mid-latitudes of western Eurasia (e.g., MOSBRUGGer et al. 2005; BRUCH et al. 2006, 2011; UtESCHER et al. 2007; IvANOv et al. 2012) comparatively few detailed studies are available for the lower latitudes of the Eastern Mediterranean. It is still a matter of debate on how humid/dry and seasonal climate was during the late Miocene period in that area. Based on the analysis of anomalies with respect to Present it has been assumed that the southeastern Mediterranean realm had about the same temperatures in the late Miocene as today (UTESCHER et al. 2011) and therefore would have expe- rienced no drastic cooling during the later Neogene. The newly recovered Gavdos megaflora, together with the availability of revised flora lists of coeval, neighbouring sites allows addressing these questions concerning the palaeoclimate conditions. Besides the documentation of the Gavdos flora, also comparisons are made with related floras and palaeoenvironments are reconstructed based on the recovered macrofossils. Eventually, additional information about the climate before the "Messinian salinity crisis" based on palaeobotanical proxies can reinforce the previous studies (e.g., Kovar-Eder et al. 2006).

The present paper gives a short overview of the so far recognized plant taxa including palaeoenvironmental interpretations based on quantitative meth- 


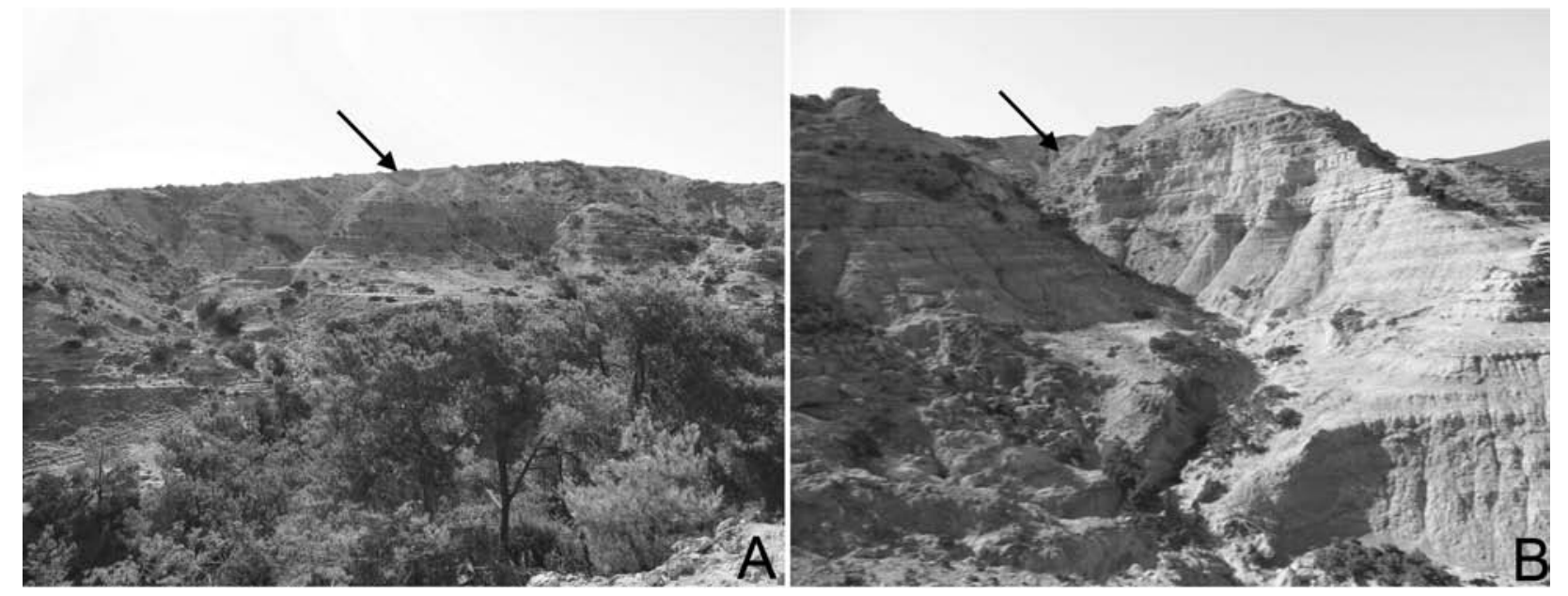

Fig. 1. A - Metochia outcrop panoramic photo. The arrow shows the position (inside the gorge) of the plant fossiliferous level consisting of sapropels and blue marls alternations (fossil-bearing site, September 2013), B - The alternations of blue marls and sands are underlying the plant fossiliferous sapropels. The arrow shows the position (inside the gorge) of the plant fossiliferous level consisting of sapropels and blue marls alternations (Metochia outcrop, September 2013).

ods, and thus contributes to expanding our knowledge about the late Neogene floras of the Mediterranean. It complements previous studies recently accomplished in southernmost Greece, namely in Crete - Makrilia (SAchse \& Mohr 1996; Sachse et al. 1999; SAchse 2004), Vrysses (Zidianakis 2002; Zidianakis et al. 2007) and Pitsidia, Messara Basin (ZiDianakis et al. 2010).

\section{Geology and palaeontology of the study area}

The island of Gavdos is situated in the southern part of Greece south of Crete (3450'0” N, 24 $5^{\circ} 0^{\prime \prime}$ E) and covers an area of $33 \mathrm{~km}^{2}$ (Fig. 2A-B). The plant fossils investigated for the present study were collected at the Metochia locality (NE Gavdos), from which also the sapropels (Postma et al. 1993), the calcareous nannoplankton (RAFFI et al. 2003; AnASTASAKIS et al. 1995), the echinoid fauna (TsaPARAs et al. 2007) and fishes (GAUdANT et al. 2005, 2006) have been studied (Fig. 1A). Also benthic foraminifera have been investigated as indicators of the palaeoenvironmental conditions of the Messinian Salinity Crisis (DrinIA et al. 2007), as well as planktonic foraminifera and geochemistry (Schenau et al. 1999; Antonarakou \& Drinia 2003; Antonarakou et al. 2007).

The first stratigraphic description and interpreta- tion of the island was by Simonelli (1894a, b). According to him the basement consists of limestones with Clypeaster altus Klein, Ostrea crassissima LAMARCK and Heterosteginids, overlain by a layer of brown marls with fossil fish and plant remains (e.g., Laurus, Cinnamomum, Callitris). The next layer consists of blue marls with Cleodora, bryozoans and crystals of selenite. Almost 80 years later, in 1970, the first detailed geological exploration of the island took place by Vicente (1970). In 2005 Tsaparas following the stratigraphic and geological notifications discussed above observed an overlying final layer of brown sandy marl containing further plant fossil remains (TSAPARAS 2005; Figs. 1B, 2C).

The Alpine substratum comprises a calcareous sequence of late Maastrichtian - Danian age and deposits of the flysch of Eocene age, which are developed in the S-SW part of the island while an ophiolithic complex consisting of a metamorphic volcano-sedimentary series (metamorphosis of Early Jurassic age) is developed towards the NE part of the island. The Mesozoic strata in the NE part of the island are overlain unconformably by Neogene sediments that are up to $150 \mathrm{~m}$ thick (VICENTE 1970; I.G.M.E. 1993). The geodynamic evolution of the island since the late Cenozoic has been studied in detail (ANASTASAKIS 1987) and the Neogene deposits of the island were divided into two formations: Potamos and Metochia formations (ANASTASAKIS et al. 1995). 


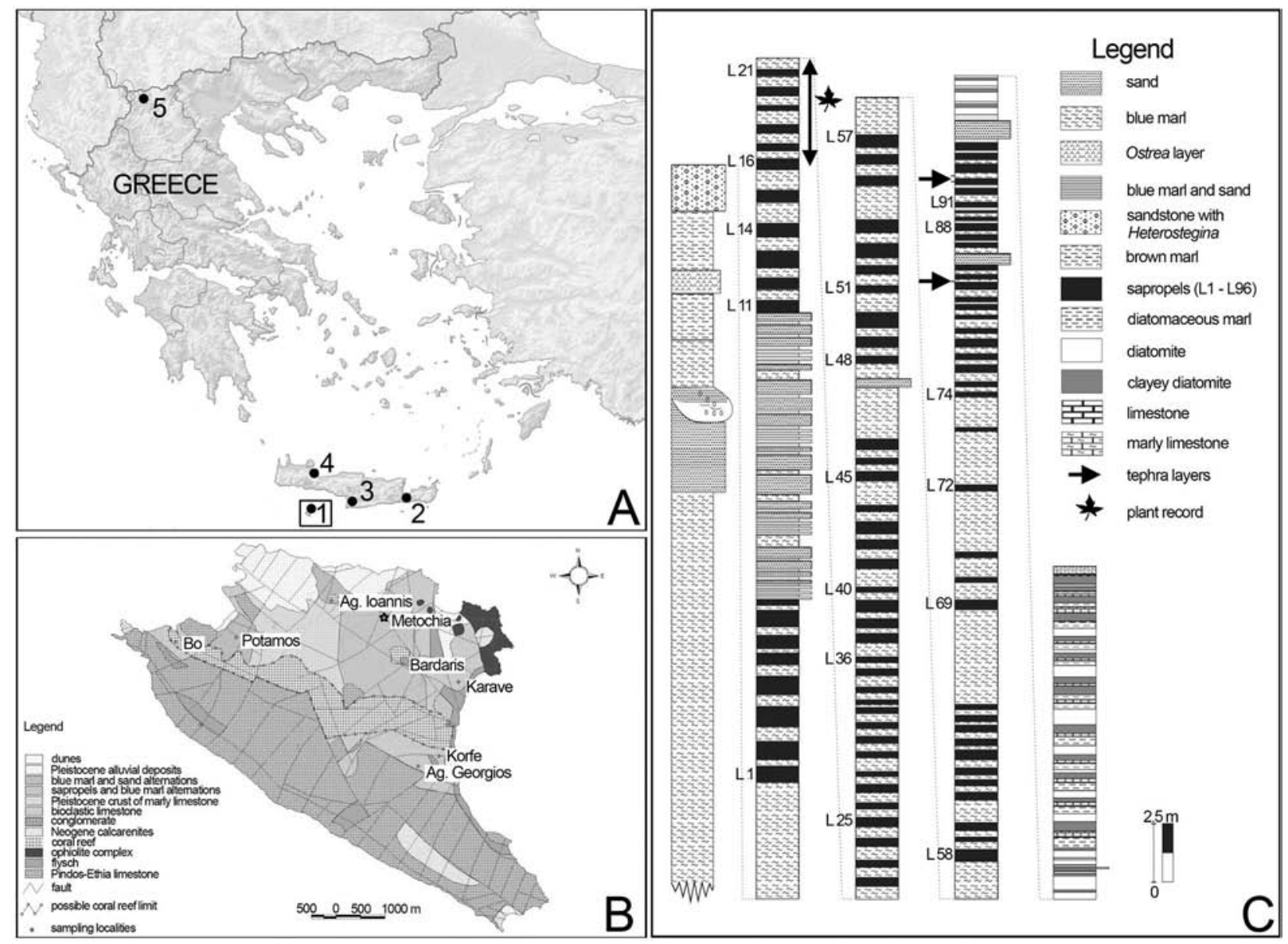

Fig. 2. A - Location of the studied floras in Greece. Floras/sites: 1. Gavdos, 2. Makrilia, 3. Pitsidia, 4. Vrysses, 5. Vegora. B - Geological map of the Gavdos Island (modified by Tsaparas 2005). C. Geological profile of Metochia (modified by TSAPARAS 2005).

The fossil plant remains studied were collected by N. TSAPARAS in 2005 from the Metochia section in the N-NE part of the island from the 'sapropels' L16 to L22 of early to middle Tortonian age (Figs. 1A, B, 2C). The term 'sapropels' is used for the thinly and faintly laminated reddish layers that mark the transition from the clayey diatomites to genuine diatomites of the Metochia section, although according to GAUDANT et al. (2006) the 'true sapropels' are the diatomaceous laminated marls. In this section the formations have a lot more than $2 \%$ organic material and according to Postma et al. (1993) they represent sapropel episodes.

Studies on various other fossiliferous localities of this island, which are stratigraphically correlated to the site of Metochia have been carried out for the purposes of palaeoenviromental reconstructions using foraminifera (DrinIA et al. 2004; DRINIA 2009), bryozoan faunas (DrinIa et al. 2009), corals and microfacies analyses (DrinIA et al. 2010), fish otoliths (TsAPARAS \& MARCOPOUlou-Diakantoni 2005) and sedimentological analyses (PomONI et al. 2013). According to TSAPARAS (2005) the predominant occurrence of the fish species Bregmaceros albyi SAUvage and Lepidopus sp. along with the co-occurrence of plant remains in the sapropels L16 - L22 suggests a maximum water depth of $300 \mathrm{~m}$.

The Metochia section (Figs. 1A, B, 2C) has been sampled in detail by TSAPARAs (2005) in order to study several perspectives and to clear it up from a stratigraphical point of view. 96 samples of sapropels (Postma et al. 1993) were taken from the outcrop (L1L96). Hilgen et al. (1995) and Krijgsman et al. (1995) 
conclude that the age of the section is 9.7-6.6 million years, including the plant fossiliferous strata related to L16-L22 sapropels (Fig. 2C) which have a thickness of $5.26 \mathrm{~m}$ and an age of 9.4-9.1 million years (HILGEN et al. 1995, Antonarakou 2001) as has been concluded from the study of the palaeomagnetism (orbital cycles according to periodic oscillations of eccentricity) and the foraminifera. The whole section has also been dated through the study of nannofossils (TRIANTAPHYLLou et al. 1999), planktonic foraminifera (ANTONARAKOU 2001), and mollusks (DeRmitZAKIs \& GeORGIADES 1987). The access to Metochia section and especially to the plant fossil-bearing site is not easy - due to the general topography and geomorphology of the area since it is situated inside a gorge (Fig. 1A, B). Two of us (NT and VK) revisited Metochia fossiliferous site on September 2013 for scientific purposes and since there was nothing changed at the already studied section they made new detail samplings collecting a lot of material for further palaeontological and stratigraphical studies.

\section{Material and methods}

The over 100 specimens of plant fossils studied here were collected by Nicolaos Tsaparas in 2005 from the Metochia section in the N-NE part of the island (Fig. 1A, B). Among the recovered specimens leaf impressions, mostly fragmented, besides twig fragments and a few fruits, prevail. The high degree of oxidation of the fossil-bearing rocks and the resulting poor preservation of most samples prevents the study of leaf anatomy and detailed morphology of the leaf lamina. Attempts to prepare cuticles from the most promising samples failed. Dark-coloured remains on the leaf lamina did not dissolve at routine maceration in Schulze solution followed by rinsing in $5 \% \mathrm{KOH}$ and obviously rep- resent mineral coatings. Some of the studied leaf material is probably affected by fungi and/or insects as it is shown from their lamina distortions (e.g., Figs. 3.7, 5.6, 5.10, 6.9, 6.10). These observations might be the subject of a future study.

The studied plant material is housed in the collection of the Department of Historical Geology-Palaeontology, Faculty of Geology and Geoenvironment, University of Athens. The specimens are numbered and the frontal letters of their codes (GAVMT) refer to the island of Gavdos and the Metochia section.

Several techniques were used to distinguish palaeoenvironmental characters of the studied flora of Gavdos and other coeval floras from Greece. The phytosociological approach (MAI 1995) and Integrated Plant Record vegetation analysis (IPR vegetation analysis sensu KOVAR-EDER et al. 2008; TeODORIDIs et al. 2011a) are used to evaluate the studied plant assemblages. The phytosociological approach classifies the palaeofloras with the usage of the following symbols for distinguishing vegetative storeys: E1 (herbs and vines), E2 (shrubs and lianas), E3 (trees under $25 \mathrm{~m}$ high) and E4 (trees over $25 \mathrm{~m}$ high). The IPR vegetation analysis is a semi-quantitative (based on taxonomic and ecological expertise and quantitative evaluation), fossil-based evaluation method which has previously been applied to Neogene and Paleogene leaf, fruit and pollen floras, with a validation based on modern vegetation sites (e.g., KovAR-EDER \& KVAČEK 2003, 2007; KovAR-EDER et al. 2008; JACQUES et al. 2011; TeODORIDIs et al. 2011a, 2012). The method is used for the classification of fossil floras in terms of zonal vegetation type. For more details the reader is referred to the original description of the method (Kovar-EDER et al. 2008).

Palaeoclimatic estimates were made using three techniques: approaches based on Leaf physiognomy, namely Leaf Margin Analysis (LMA) and Climate Leaf Analysis Multivariate Program (CLAMP), approaches based on taxonomy, and the Coexistence Approach (CA) which is based on interpretation of the Nearest Living Relative (NLR). LMA, which only estimates mean annual temperature (MAT), has been applied on all four leaf floras while CLAMP only on three.The flora of Pitsidia was excluded from the CLAMP analysis because of the low number

Fig. 3. 1. Tetraclinis salicornioides (UNGER) KVAČEK, incomplete foliage twig; GAVMT 420, scale bar $10 \mathrm{~mm}$ segments; 2. Tetraclinis salicornioides (UNGER) KVAČEK, detached leafy segment, GAVMT 416, scale bar 5 mm; 3 . Tetraclinis salicornioides (UNGER) KVAČEK, detached leafy segment, GAVMT 619, scale bar 3 mm; 4. Taxodium dubium (STERNBERG) HEER, foliage shoot, GAVMT 652, scale bar 10 mm; 5. Pinus sp., needle fragment, GAVMT 602, scale bar 3 mm; 6 . Pinus sp., needle fascicle, GAVMT 446, scale bar 5 mm; 7. Laurophyllum sp., incomplete leaf, GAVMT 327, scale bar 10 mm; 8 . Laurophyllum sp., petiolate leaf base, GAVMT 555, scale bar $10 \mathrm{~mm}$; 9. Laurophyllum sp., incomplete petiolate leaf, GAVMT 481, scale bar $10 \mathrm{~mm}$; 10. Daphnogene sp., leaf with suprabasal acrodromous venation, GAVMT 391, scale bar 10 mm; 11. Daphnogene sp., leaf petiolate with suprabasal acrodromous venation, GAVMT 485, scale bar 10 mm; 12. Daphnogene sp., obovate leaf, GAVMT 479, scale bar 5 mm; 13. ?Lindera ovata KolAKOvsKy, leaf petiolate with basal acrodromous venation, GAVMT 338, scale bar $10 \mathrm{~mm}$; 14. ?Lindera ovata KolAKOvSKY, incomplete leaf petiolate with basal acrodromous venation, GAVMT 383, scale bar 5 mm; 15. ?Lindera ovata KolAKovsky, leaf with basal acrodromous venation, GAVMT 496, scale bar $10 \mathrm{~mm}$; 16. leaf counter-impression of Fig. 3.15, GAVMT 617, scale bar $10 \mathrm{~mm}$; 17. ?Sassafras sp., fragment of large lobed leaf, GAVMT 432, scale bar $10 \mathrm{~mm}$; 18. Monocotyledonae fam. et gen. indet., leaf fragments with parallel venation, GAVMT 349, scale bar $10 \mathrm{~mm}$; 19. Monocotyledonae fam. et gen. indet., leaf fragment with parallel venation, GAVMT 610, scale bar $10 \mathrm{~mm}$. 

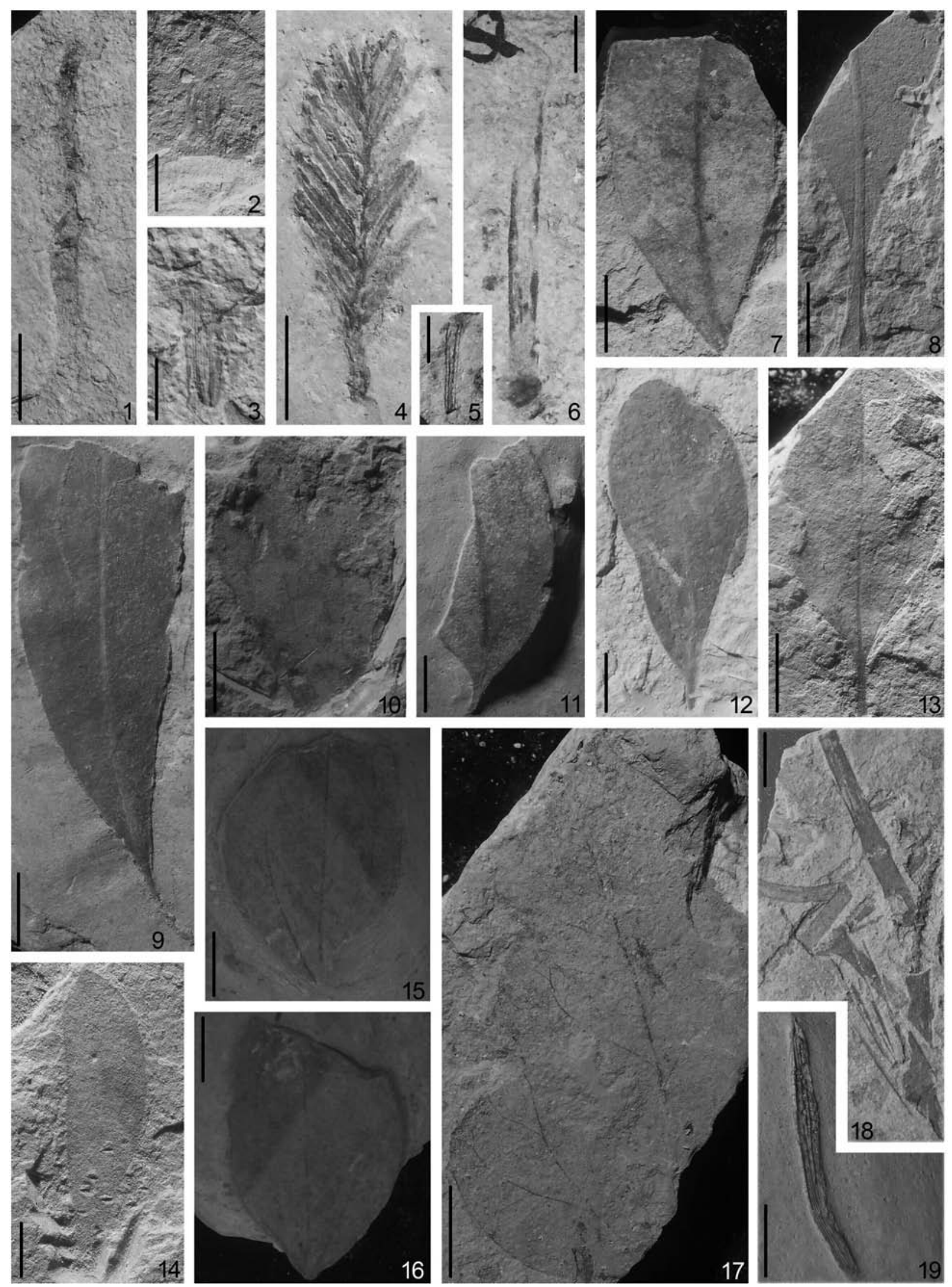

Fig. 3. 
of woody dicots. The LMA technique $\left(\mathrm{LMA}_{1-3}\right)$ uses linear equations published by Wolfe (1979), Su et al. (2010) providing a linear regression equation for East Asian vegetation, and TRAISER et al. (2005), based on European vegetation, together with an equation of the sampling error according to MiLler et al. (2006). The CLAMP method uses physiognomic characteristics of the studied plant assemblage presented in Appendix 1, and the physiognomic and gridded meteorological calibration datasets from 144 sites (for Vrysses and Makrilia sites) and from 189 sites (for Gavdos site) - see SPICER (2013) selected by a statistical tool published by TEODORIDIS et al. (2011b) and recently modified by TEODORIDIs et al. (2012). The application of CLAMP follows the procedure explained on the CLAMP website (http://clamp.ibcas.ac.cn/) (cf. also Wolfe \& SPICER 1999; SPICER et al. 2009). CLAMP provides estimates for 3 temperature (MAT, WMMT - warmest month mean temperature, CMMT - coldest month mean temperature) and 2 precipitation variables (3-WET - precipitation during 3 consecutive wettest months, 3 -DRY - precipitation during 3 consecutive driest months).

The application of the Coexistence Approach follows the description of the method provided by MosBrugGer \& Utescher (1997) and Utescher et al. (2014). Climate data for the Nearest Living Relatives identified for the fossil taxa were retrieved from the current version Palaeoflora Database (Utescher \& Mosbrugger, 2013). According to the standard of the method, 3 temperature (MAT, WMMT, CMMT) and 4 precipitation variables (MAP - mean annual precipitation, MPwet - wettest month precipitation, MPdry - driest month precipitation, MPwarm - warmest month precipitation) are reconstructed. The CA can be applied to all fossil taxa based on various organs allowing systematic assessment.

\section{Systematic descriptions}

In the systematic descriptions angiosperm taxa are arranged according to the classification suggested by recent molecular phylogenetic studies (see JuDD et al. 2002; CHRISTENHUSZ et al. 2011; REVEAL 2012) which follow the classification of Angiosperm Phylogeny Group II (2003) and III (2009). Leaf architecture in general is described following current terminology published by Ash et al. (1999) and ElLIS et al. (2009). Leaf lamina size categories follow the leaf size template of CLAMP (SPICER 2013), which is based on the original concept of WeBB (1959), where microphyll 3 and mesophyll 1 categories are equal to notophyll leaf size and mesophyll 2 and 3 to macrophyll leaves.

Only most relevant synonyms are quoted in a way currently used in the palaeobotanical literature.

\section{Conifers \\ Cupressaceae \\ Tetraclinis MASTERS}

Tetraclinis salicornioides (UNGER) KVAČEK Figs. 3.1-3.3
1847 Thuites salicornioides Unger, p. 11, pl. 2, figs. 1-4, pl. 20, fig. 8.

1989 Tetraclinis salicornioides (UNGER). - KVAČEK, p. 48, pl. 1, fig. 11, pl. 2, figs. $2-14$, pl. 3, figs. 1-4, text-fig. 1.

(For further synonyms see KvAČEK 1989)

Material: Detached leafy segments and one incomplete foliage twig (GAVMT 416, GAVMT 420, GAVMT 619).

Description: Incomplete foliage twig, $38 \mathrm{~mm}$ long, detached leafy segments corresponding to pseudowhorls, 10 and $18 \mathrm{~mm}$ long, 3 and $8 \mathrm{~mm}$ wide, composed of pairs of dimorphic facial and lateral leaves, at base rounded to truncate, apically obtuse in simple segments or bluntly mucronate in obovate segments from the middle of the foliage sprays, 3 to 5 prominent longitudinal lines seen on surface.

Discussion: According to KVAČEK et al. (2000), until being recognized as Tetraclinis by attached cones and associated seeds (KvAČEK 1989), this conifer was considered to belong to an extinct genus, for which the invalidly published name Hellia Unger [see BŮŽEK et al. 1976] (e.g., MAI 1963; FrIIS 1977) and recently rejected Libocedrites ENDLICHER [see ZIJISTRA \& KVAČEK 2010] (e.g., KNOBLOCH \& KVAČEK 1976; MAI \& Walther 1978; Palamarev et al. 1991; Wilde \& FrankenHÄUSER 1998) were applied. The term cladode-like is used in reference to the foliar branch segments which are distinguished from true cladodes (derived from branches without leaves) by their derivation from fully merged leaves with the branch. Theses segments consist of mutually fused dimorphic scale leaves borne in pseudowhorls. The complete fusion of lateral and facial leaves does not occur among extant Cupressaceae (not even in the extant species of Tetraclinis) but does occur in both the European and North American populations of T. salicornioides.

According to KVAČEK et al. (2000) the foliage segments of $T$. salicornioides are broader and more flattened than those of another fossil representative of this genus, $T$. brachyodon (BRONGNIART) MAI \& WALTHER and appear to be adapted to more mesic conditions. The same morphology of foliage segments is developed in another extinct conifer Ditaxocladus S.X. Guo \& Z.H. Sun from the Upper Cretaceous and Palaeocene (Guo et al. 2012).

Tetraclinis Masters has a single extant species, Tetraclinis articulata (VAHL) MASTERS, that is native to warm, summer-dry climates (Cs) of northern Africa, Malta, and southern Spain. This living representative does not reflect the autecology of the fossil Tetraclinis salicornioides (KVAČEK 2007) and should not be used for palaeoenvironmental considerations. T. salicornioides was formerly distributed over large parts of Europe since the Eocene (MEYER \& MANCHEster 1997; KVAČEK et al. 2000), having been always connected with humid subtropical to warm-temperate vegetation. It is also represented in the Makrilia outcrop by twigs, a seed and a seed cone partly identified as Tetraclinis sp., ?Tetraclinis (SACHSE 2004) or Tetraclinis brachyodon (SACHSE et al. 1999; SACHSE \& Mohr 1996), and in the Vrysses outcrop (ZIDIANAKIs et al. 2007). 


\section{Taxodium L. C. RICHARD \\ Taxodium dubium (Sternberg) HeER}

Fig. 3.4

1823 Phyllites dubius Sternberg, p. 37, pl. 36, fig. 3; 1825 , tentamen \& index.

1853 Taxodium dubium Sternberg. - Heer, p. 136.

1976 Taxodium dubium (STERnberg) Heer. - KvaČeK, p. 290, text-figs. 5-6.

1977 Sequoia langsdorfii (Brongniart) Heer. - VelitzeLOS \& SCHNEIDER, p. 174, pro parte, fig. 6 (? non fig. 5).

(For full synonymy see Kunzmann et al. 2009).

Material: Incomplete foliage shoots (GAVMT 629, GAVMT 652).

Description: Foliage shoots with flattened needles, lanceolate in outline, 13 and $39 \mathrm{~mm}$ long, $15 \mathrm{~mm}$ wide, needles linear to lanceolate, apex acute, base shortly petiolate and rounded, distichously arranged, alternate at unequal distances, univeined with strong and distinct midrib.

Discussion: The sterile foliage shoots of Taxodium and Sequoia are difficult to distinguish without the aid of epidermal structure. Nevertheless, the shoots of the Sequoia sempervirens type are usually not narrowing to the shoot apex and the length of the needles is approximately uniform. Taxodium dubium fossils have been found also in other localities of Greece, such as in Vegora (KvAČEK et al. 2002), in the Makrilia outcrop (SACHSE \& MoHR 1996; SACHSE et al. 1999; SACHSE 2004) and the Pitsidia outcrop (ZiDIANAKIs et al. 2010). The nearest living relatives of this taxon are $T$. distichum and $T$. mucronatum, representatives of swamp vegetation in subtropical and warm temperate climates as deciduous and hygrophilic trees, native in the SE USA and Mexico to Guatemala, respectively (KvAČEK et al. 2002; KunZmann et al. 2009).

\section{Pinaceae Pinus L. \\ Pinus sp. (folia) \\ Figs. 3.5-3.6}

Material: Needle leaf fragments (?GAVMT 345, GAVMT 446, ?GAVMT 570, GAVMT 602).

Description: Double-needled fascicles, rounded at base, sheath and apex not preserved, needles partly isolated, fragmentary, in preserved length of 8 to $43 \mathrm{~mm}, 2$ to $2.6 \mathrm{~mm}$ wide, straight or slightly curved, univeined, margin entire.

Discussion: The recovered pine needles belong to subgenus Pinus (Diploxylon pines), although typical persistent sheaths are not preserved on fascicles due to transportation. Among the findings from the Makrilia outcrop in Crete,
2- and 5-needle fascicles of Pinus spp. are known (SACHSE \& Mohr 1996; SachSe et al. 1999; SachSe 2004). In the Vrysses outcrop, fossil pine foliage also occurs (ZIDIANAKIs et al. 2007), partly in fascicles of two, usually thinner than in Gavdos. The pine needles in the Pitsidia outcrop are in fascicles of three and co-occur with winged seeds (ZidianAKIS et al. 2010).

\section{Angiosperms \\ Lauraceae \\ Laurophyllum GÖPPERT}

\section{Laurophyllum sp.}

Figs. 3.7-3.9

Material: Incomplete leaves and fragments (GAVMT 327, GAVMT 412, GAVMT 418, GAVMT 458, GAVMT 465, GAVMT 481, GAVMT 505, GAVMT 555, GAVMT 592, GAVMT 604, GAVMT 644).

Description: Leaves simple, petiolate, lamina elliptic to obovate, 40 to $85 \mathrm{~mm}$ long, 18 to $30 \mathrm{~mm}$ wide, base cuneate, narrowed into petiole (up to $12 \mathrm{~mm}$ long), apex not preserved, margin entire; venation brochidodromous, midrib strong, straight or slightly curved, secondary veins at an angle of 45 to $60^{\circ}$, looping near margin, alternate, intersecondaries thinner and parallel, tertiary veins perpendicular, straight to sinuous, venation of the higher orders poorly preserved, regular polygonal reticulate, areolation well developed, 3 or 4 sided, veinlets not preserved.

Discussion: Similar leaves of the Laurophyllum-type are among the findings from the Makrilia outcrop (SACHSE \& Mohr 1996; Sachse et al. 1999; SACHSE 2004, as Laurophyllum princeps, Laurophyllum bournense and ?Laurophyllum Typ 1,2). The lack of leaf anatomical structure prevents an exact identification and comparisons.

\section{Daphnogene UnGER}

\section{Daphnogene sp.}

Figs. 3.10-3.12

Material: Incomplete leaves and fragments (GAVMT 355, GAVMT 391, GAVMT 392, GAVMT 440, GAVMT 479, GAVMT 485, GAVMT 500).

Description: Leaves simple, petiolate, lamina widely elliptic to obovate, 40 to $90 \mathrm{~mm}$ long, 18 to $27 \mathrm{~mm}$ wide, base rarely asymmetric, cuneate with petiole up to $6 \mathrm{~mm}$ long, apex shortly acuminate to blunt, margin entire, venation suprabasal acrodromous, midrib strong, moderate, straight or slightly curved in apical part, lateral veins thinner, alternate or opposite, at an angle of 20 to $40^{\circ}$, running along margin, usually connecting secondaries in $2 / 3$ of the blade length, secondary veins thinner, alternate, at an angle of 40 to $50^{\circ}$, 
curved and looping along margin or straight between midrib and lateral veins, venation of the higher orders poorly preserved.

Discussion: The fossils at hand are not assignable to a species without the cuticle structure. Similar leaf fossils from the Vegora flora were assigned to Daphnogene pannonica KvaČEK \& KNOBloch (KVAČEK et al. 2002), which differs in thinly cutinized leaf epidermis from Cinnamomum polymorphum, widely distributed in the European earlymiddle Miocene. Among the findings from the Makrilia outcrop are two similar leaves (SACHSE 2004) assigned to Cinnamomophyllum sp. The leaf fragment assigned to Cinnamomophyllum polymorphum by SACHSE (2004, pl. 11, fig. 12) was obviously misidentified because of major differences in the venation. The material of Daphnogene similar to the Gavdos specimens was recorded in the Vrysses (ZidiAnAKIs et al. 2007) as well as in the Pitsidia outcrops (ZIDIANAKIs et al. 2010).

\section{Lindera THunB.}

\section{? Lindera ovata KOLAKOvSKY}

Figs. 3.13-3.16

? 1957 Lindera ovata KolaKovsKy, p. 277, pl. 14, figs. 4-5; pl. 15 , fig. 1.

? 1964 Lindera ovata KolaKovsKy. - KolakovsKy, p. 106107 , pl. 40, figs. $1-5$.

? 1967 Lindera cf. L. ovata Kolakovsky. - PetKova, p. 142, pl. 5, fig. 6, pl. 12, fig. 4 .

? 1984 Lindera ovata Kolakovsky. - Kitanov, p. 51, pl. 7, fig.1.

Material: Incomplete leaves and fragments (GAVMT 338, GAVMT 369, GAVMT 383, GAVMT 448, GAVMT 496, GAVMT 539, GAVMT 617).

Description: Leaves simple, petiolate, lamina widely elliptic to ovate, 40 to $60 \mathrm{~mm}$ long, 20 to $32 \mathrm{~mm}$ wide, base symmetric or rarely slightly asymmetric, widely cuneate to rounded, with petiole up to $5 \mathrm{~mm}$ long, apex not preserved, margin entire, venation basal acrodromous, midrib strong, straight to curved, lateral veins thinner, alternate or opposite, at an angle of 20 to $30^{\circ}$, running along margin, secondary veins thinner, alternate, curved and looping at margin or straight steeply ascending between midrib and lateral veins, venation of the higher orders poorly preserved.

Discussion: KolaKovsky (1957, 1964, pl. 40, figs 1-5) described this species from the Kodor River palaeoflora assemblages without the cuticle structure or any other leaf anatomical character. Thus the affinity to the Lauraceae is not well supported, being based entirely on gross morphology. The assignment to the genus Lindera is also equivocal.

Similar fossils were described from the Bulgarian palaeoflora by PALAmARev et al. (2005, pl. 4, fig. 4) as Matudaea palaeobalcanica (Hamamelidaceae). In ZIDIANAKIs et al. (2007, fig. 3N-P) both morphotypes are noted as cf. Ziziphus ziziphoides, while in SACHSE $(1997,2004)$ they are referred to as Dicotylophyllum type 3. KvAČEK \& HABLY (1991: 81, pl. 9, fig. 4) described different morphotypes from the Hungarian Oligocene as Ziziphus cf. ziziphoides (UNGER) Weyland. Among the findings from the Makrilia outcrop, similar leaves are referred to as ?Rhamnaceae (SACHSE \& Monr 1996), or Dicotylophyllum Typ 3 (SACHSE et al. 1999, SACHSE 2004) matching the Lindera ovata specimens of the current study. In the Vrysses outcrop such leaves, similar to our Lindera ovata, also occur and have been assigned to cf. Ziziphus ziziphoides (UNGER) WEYLAND (ZIDIANAKIs et al. 2007). Because of finely dentate margin (ZIDIANAKIs et al. 2007 , fig. $3 \mathrm{~N}, \mathrm{P}$ ), this material may belong to the Rhamnaceae.

The diagnostic tertiary venation is not well preserved in our material, but the tertiary veins are steep and not dense and at wide angles contrary to the fossil foliage of Ziziphus (Rhamnaceae), which differs also in mostly finely serrate margins (e.g., KVAČEK \& HABLY 1991).

Sassafras T. NEES

? Sassafras sp.

Fig. 3.17

Material: Incomplete simple leaves (GAVMT 432, GAVMT $505)$.

Fig. 4. 1. Fagus gussonii Massalongo emend. Knobloch \& Velttzelos, leaf, GAVMT 473 scale bar 10 mm; 2 . Fagus gussonii Massalongo emend. Knobloch \& Velitzelos, leaf, GAVMT 492, scale bar $10 \mathrm{~mm}$; 3. Fagus gussonii Massalongo emend. KNOBLOCH \& Velitzelos, leaf, GAVMT 534, scale bar $10 \mathrm{~mm}$; 4. Leguminocarpon sp., fragment of a pod with large seeds, GAVMT 567, scale bar $5 \mathrm{~mm}$; 5 . Leguminosites sp. 1, leaflet of broad and elliptic shape, GAVMT 321, scale bar $5 \mathrm{~mm}$; 6. Leguminosites sp. 1, leaflet of broad and elliptic shape, GAVMT 503, scale bar 10 mm; 7. Leguminosites sp. 2, leaflet of narrow and elliptic shape, GAVMT 550, scale bar $5 \mathrm{~mm}$; 8. Leguminosites sp. 2, leaflet of narrow and elliptic shape, GAVMT 552, scale bar 5 mm; 9. Leguminosites sp. 3, large leaflet with petiolule, GAVMT 524, scale bar 10 mm; 10. Leaflet venation of Fig. 4.9, scale bar 10mm; 11. Leguminosites sp. 4, basal part of elliptic leaflet, GAVMT 532, scale bar $10 \mathrm{~mm}$; 12. Leguminosites sp. 4, basal part of ovate leaflet, GAVMT 562, scale bar $10 \mathrm{~mm}$; 13. Paliurus tiliifolius (UNGER) BŮŽEK, incomplete leaf base, GAVMT 520, scale bar $10 \mathrm{~mm}$; 14. Sapindus graecus UngER, incomplete leaflet, GAVMT 567 left, scale bar $10 \mathrm{~mm}$; 15. Detail of leaflet venation, GAVMT 567 left, scale bar $5 \mathrm{~mm}$; 

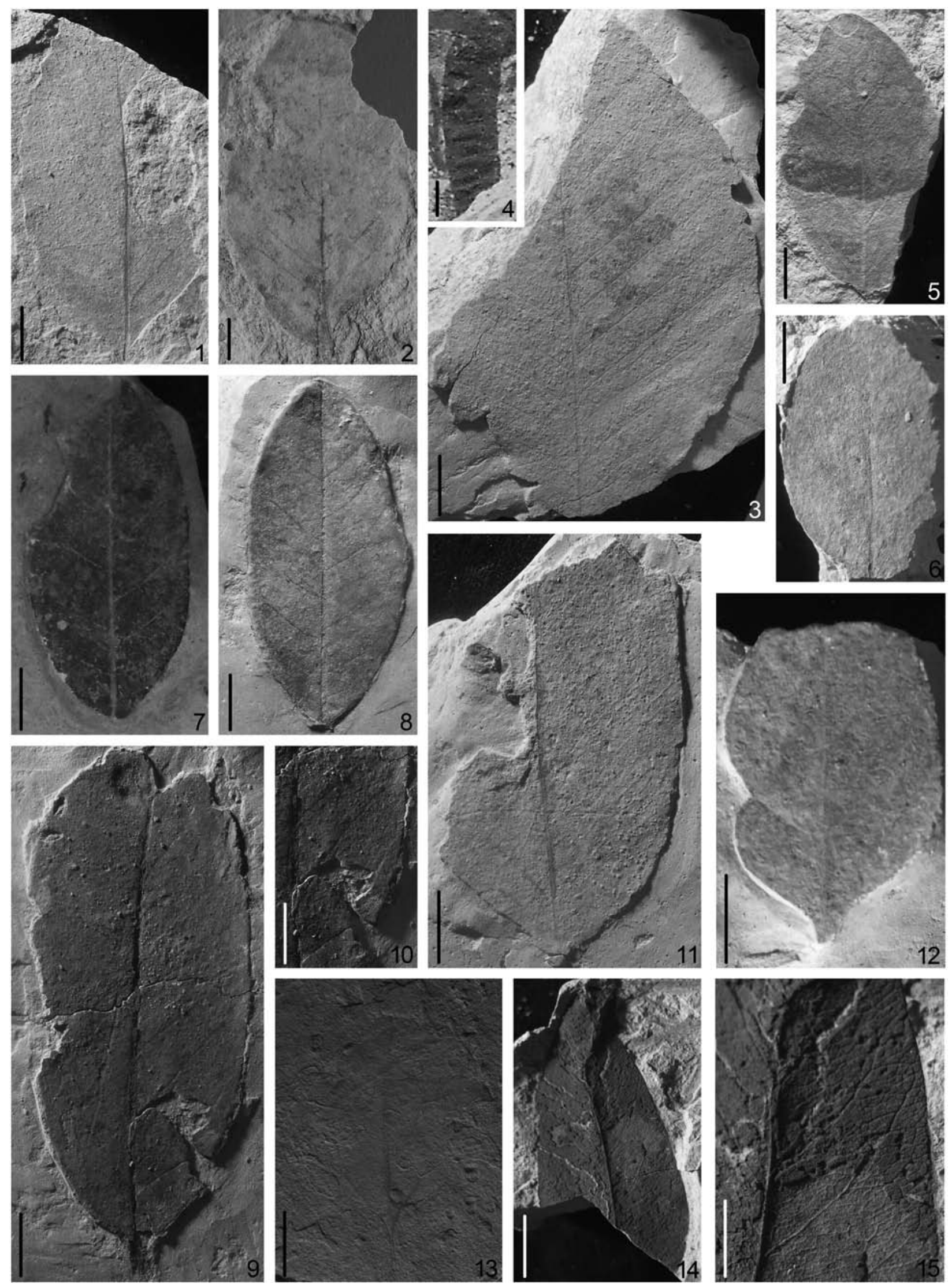

Fig. 4. 
Description: Leaves simple, lamina widely elliptic, 32 and $65 \mathrm{~mm}$ long, 23 and $35 \mathrm{~mm}$ wide, base incomplete, rounded, apex blunt, margin entire, with one large lobe preserved; venation brochidodromous, midrib strong, straight, suprabasal veins slightly thicker, curved, alternate, higher secondary veins thinner, curved, looping along margin, alternate, at angles of 30 to $50^{\circ}$, tertiary veins perpendicular, straight to sinuous, often forked, venation of the higher orders poorly preserved, regular polygonal reticulate, areolation well developed, mainly 4-sided, small glands in axiles of secondaries indistinct.

Discussion: One of the specimens at hand may represent a trilobed leaf, which is similar to Sassafras ferretianum MASSALONGO (see KVAČEK et al. 2002: 116 f., pl. 3, fig. 6, pl. 4). The possible misidentification of these specimens with, e.g., Acer tricuspidatum BronN (cf. Hably 1992, pl. 4, fig. 3), cannot be ruled out, but in our opinion it is improbable due to the marginal venation. The lobed leaves of the modern representatives of the Moraceae (e.g., Morus) differ in the toothed margin. On the other hand, the described incomplete leaves may resemble also foliage of Liriodendron $\mathrm{L}$.

\section{Monocotyledonae}

Monocotyledonae fam. et gen. indet. Figs. 3.18-3.19

Material: Fragments of leaves (GAVMT 323, GAVMT 349, GAVMT 428, GAVMT 588, GAVMT 610).

Description: Leaves strap-like, variable in sizes, with parallel venation, margin entire.

Discussion: These leaf remains may belong to sedges bordering the water. Their exact identification remains open. According to KVAČEK et al. (2002) the nearest living relatives of this aggregate taxon probably correspond to hygrophyllic (?) representatives of grass-like monocots. Similar remains of Monocotyledonae recovered in the Vrysses and Pitsidia outcrops have been assigned to two types of Poaceae/Cyperaceae (ZIDIANAKIs et al. 2007, 2010).

\section{Fagaceae} Fagus L.

\section{Fagus gussonii Massalongo emend. KnOBLOCH \& VELITZELOS}

Figs. 4.1-4.3

1858 Fagus gussonii MASSAlongo, p. 37.

1859 Fagus gussonii Massalongo. - Massalongo \& ScaRABELLI, p. 202, pl. 25, figs. 2, 5.

1979 ? Fagus attenuata GöPPERT. - MÄDLER \& StefFens, p. 15 , pl. 4 , fig. 2.

1986 Fagus gussonii Massalongo emend. KNOBLOCH \& Velitzelos, p. 9, pl. 2, figs. 2-4, 6-8, pl. 5, fig. 11, pl. 6 , fig. 5 .
1994 Fagus gussonii Massalongo. - BARrón \& DiéGUeZ, p. 23, text-fig. 2.1, 2.2, 3.1-3.3, 4.

1994 Fagus pristina SAPORTA. - BARrón \& DiÉguez, p. 23, text-figs. 2.3, 2.4, 3.4, 3.5, 5 .

1996 Fagus sp. - SACHSE \& MoHR, p. 162, text-fig. 3.2, 3.5.

1999 Fagus gussonii Massalongo. - Velitzelos \& KvaČEK, p. 420, pl. 1, fig. 1 .

1999 Fagus type gussonii Massalongo. - SAChSE et al., pp. 367,370 , fig. $1.1,1.5$.

2002 Fagus gussonii Massalongo. - KvačeK, Velitzelos \& Velitzelos, p. 61, pl. 6, figs. 1-7, pl. 7, figs. 1-5, pl. 29, figs. 3-4.

2004 Fagus gussonii Massalongo. - Denk, pp. 9-11, fig. 12.

(For further synonyms see DENK 2004)

Material: Incomplete leaves and fragments (GAVMT 334, ?GAVMT 460, GAVMT 473, GAVMT 492, GAVMT 513, GAVMT 534, GAVMT 596).

Description: Leaves simple, petiolate, lamina widely elliptic to ovate, 36 to $85 \mathrm{~mm}$ long and 28 to $55 \mathrm{~mm}$ wide, apex acute to shortly acuminate, base mostly symmetric, cuneate to widely cuneate, with fragmentary petiole up to 5 $\mathrm{mm}$ long, margin simple widely serrate, teeth acute, poorly preserved, venation craspedodromous, midrib moderately strong, straight, secondary veins thin, numerous, regularly spaced, straight, alternate, at an angle of 30 to $60^{\circ}$, tertiary veins alternate percurrent, straight to convex, venation of the higher orders regular, polygonal reticulate; areolation well developed, 3- or 4-sided; veinlets dichotomous.

Discussion: In Kolakovsky (1964, pl. 26, figs. 5-6) this fossil morphotype was assigned to $F$. orientalis LIPSKY fossilis. However, even this material belongs in our opinion to Fagus gussonii Massalongo emend. Knobloch \& Velitzelos (see KVAČEK et al. 2002: 61, 62, 96, pl. 5, figs. 1-9, pl. 6, figs. 1-7, pl. 7, figs. 1-5). SACHSE et al. (1999) and SACHSE (2004) found ten fragments of the Fagus gussonii type (partly as Fagus Typ attenuata) in the Makrilia outcrop. ZiDIANAKIS et al. (2007) recovered impressions assigned to Dicotylophyllum sp. 9, which might be related to the genus Fagus L., but more and better preserved material is needed in order to prove such a hypothesis. In ZiDIANAKIs et al. (2010) the same morphotype is noted as Fagus type attenuata. According to DENK (2004) among the three taxa of Fagus recognized for the Cenozoic of Europe [a) Fagus castaneifolia UnGER 1847; b) Fagus gussonii Massalongo 1858 emend. KNOBLOCH \& VelitZelos 1986; c) Fagus haidingeri Kováts 1856 sensu KNOBLOCH 1969] Fagus gussonii is the only straightly comparable to a few modern species and the one which is geographically and stratigraphically most restricted. The distribution of Fagus gussonii has been reported in DENK et al. (2011), with its southeasternmost limit in the flora of Makrilia (Crete Island, Greece), and its northwesternmost limit in Iceland. The nearest living relative of this taxon is Fagus sylvatica L. subsp. orientalis (LIPSKY) GREUTER \& BuRdet $(=F$. orientalis L.) - a deciduous and mesic tree, a representative of warm-temperate climates of SE Europe and the Near East (see KvačEK et al. 2002; DenK \& Grimm 2009) which comprises several leaf morphotypes (DENK, 
1999a, b; Denk et al. 2002). This is also the case with $F$. gussonii.

\section{Fabaceae \\ Leguminocarpon GÖPPERT \\ Leguminocarpon sp.}

Fig. 4.4

Material: Incomplete pod (GAVMT 567 right).

Description: Pod flat, oblong in outline, indehiscent, 12 $\mathrm{mm}$ long and $3 \mathrm{~mm}$ wide, apical and basal parts not preserved, 8 prominent outlines of oval seed chambers transversally oriented to the length of the fruit, ca. $2.5 \mathrm{~mm}$ long and $0.5 \mathrm{~mm}$ wide, fruit wall membranous, structure of upper surface not preserved.

Discussion: Similar morphotypes are referred to as Leguminocarpon sp. in KVAČEK \& HABLY (1991, pl. 10, figs. 1-3) or Leguminosites palaeogaea or L. hesperidum (UNGER) Kovar-Eder \& Kvaček (Kovar-Eder et al 2004, pl. 9, figs. 1-4). Such fruits were assigned to the genus Senna MiLL. among the Eocene legumes of North America (HERENDEEN 1992: 96, 97, 102, fig. 57).

\section{Leguminosites Bowerbank emend. SCHIMPER}

\section{Leguminosites sp. 1}

Figs. 4.5-4.6

Material: Complete leaflets (GAVMT 321, GAVMT 503).

Description: Leaflets elliptic, 30 and $43 \mathrm{~mm}$ long, 17 and $24 \mathrm{~mm}$ wide, base slightly asymmetric, rounded, petiolule fragmentary, short and thick, apex rounded, margin entire, venation brochidodromous, midrib strong, straight, secondary veins thinner, looping, alternate, at angles of 30 to $50^{\circ}$, irregularly spaced, tertiary veins alternate percurrent, straight to curved, venation of the higher orders poorly preserved.

Discussion: Among the findings from the Makrilia outcrop nine various genera of legumes have been listed (SACHSE \& Mohr 1996; SACHSE et al. 1999; SACHSE 2004) and some may partly correspond to our records. According to KVAČEK et al. (2002) such legumes are difficult to identify but may belong to deciduous representatives typical of drier climate. Leaflets assigned to Leguminosae gen. indet. and Podocarpium podocarpum have also been reported from the Pitsidia outcrop of the Messara Basin (ZiDianaKis et al. 2010).

\section{Leguminosites sp. 2}

Figs. 4.7-4.8

Material: Incomplete leaflets (GAVMT 494, GAVMT 550, GAVMT 552).
Description: Leaflets elliptic to obovate, 37 to $50 \mathrm{~mm}$ long and 14 to $23 \mathrm{~mm}$ wide, base symmetric, widely cunate to rounded with fragmentary, up to $4 \mathrm{~mm}$ long petiolule, apex rounded, margin entire, venation brochidodromous, midrib strong, straight, secondary veins thinner, looping, alternate, at angles of 45 to $65^{\circ}$, intersecondaries vaguely seen, thinner, parallel, tertiary veins alternate percurrent, straight to curved, venation of the higher orders regular polygonal reticulate, areolation well developed, areoles 3 or 4 sided.

Discussion: This legume differs in a more elongate form of leaflets from Leguminosites sp. 1. Also in this case, this taxon may belong to some of Leguminosae with deciduous foliage. Similar material of legumes has been also referred from the Pitsidia outcrop (ZIDIANAKIs et al. 2010).

\section{Leguminosites sp. 3}

Figs. 4.9-4.10

Material: Incomplete leaflet (GAVMT 524).

Description: Leaflet elliptic, $105 \mathrm{~mm}$ long and $42 \mathrm{~mm}$ wide, base symmetric, widely cunate with fragmentary 6 $\mathrm{mm}$ long petiolule, apex incomplete, probably rounded, margin entire, venation brochidodromous, midrib strong, straight, secondary veins thinner, relatively numerous, regularly spaced, alternate, at angles of 45 to $60^{\circ}$, looping, intersecondaries indistinct, thinner, parallel, tertiary veins alternate percurrent, straight to curved, venation of the higher order not preserved.

Discussion: This single leaflet differs from the previously described morphotypes by its larger size. Such leaflets of legume foliage are not common. In the Makrilia outcrop, similar morphotypes are referred to as Dicotylophyllum typ 12 or Juglandaceae vel Lauraceae (SACHSE et al. 1999, text-figs. 2.38, 2.44). Leguminosae gen. indet. has been also referred from the Pitsidia outcrop (ZIDIANAKIs et al. 2010). Some foliage ascribed to Dicotylophyllum sp. 5 (ZIDIANAKIS et al. 2007) from Vrysses may belong to a similar morphotype.

\section{Leguminosites sp. 4 \\ Figs. 4.11-4.12}

Material: Incomplete leaflets and fragment (GAVMT 349, GAVMT 532, GAVMT 562).

Description: Leaflets elliptic to ovate, 25 to $65 \mathrm{~mm}$ long, 27 to $37 \mathrm{~mm}$ wide, base symmetrical, cuneate, apex not preserved, margin entire, venation brochidodromous, midrib strong, secondary veins much thinner, densely arranged, straight, rarely curved, looping along margin, alternate, at angles of $30-60^{\circ}$, intersecondary veins thinner, parallel, venation of the higher orders poorly preserved.

Discussion: Our specimens are similar to the material ascribed to Leguminosites sp. 3 (Pl. 3, fig. 13) but differs in 
much more dense venation. It matches foliage from the Kodor Upper Miocene assigned to Salix integra GöPp. ? (KolAKOVSKY 1964, pl. 52, fig. 4) or ?Dalbergia bella HeER sensu Kolakovsky (1964, pl. 43, fig. 1).

\section{Rhamnaceae \\ Paliurus MiLl. \\ Paliurus tiliifolius (UNGER) BŮŽEK}

Fig. 4.13

1847 Paliurus favonii Unger, p. 147, pro parte, pl. 50, figs. 7-8 (non fig. 6 left).

1847 Ceanothus tiliaefolius UNGER, p. 143, pl. 49, figs. 1-6.

1850 Paliurus favonii Unger, p. 463, pro parte.

1864 Ziziphus tremula UNGER, p. 16, pl. 3, fig. 39.

1864 Ziziphus renata UnGer, p. 16, pl. 3, figs. 40, 41.

? 1864 Ziziphus protolotus UnGER, p. 17, pl. 3, fig. 43.

1971 Paliurus tiliaefolius (UNGER). - BŮŽEK, p. 74, pl. 33, figs. 1-21; pl. 34, figs. 1-17.

Material: Incomplete leaf (GAVMT 520).

Description: Leaf simple, lamina widely ovate, $55 \mathrm{~mm}$ long and $30 \mathrm{~mm}$ wide, base slightly truncate with a $10 \mathrm{~mm}$ long petiole, apex not preserved, margin entire to undulate, venation tri-veined, midrib strong, straight, basal lateral veins originating at 30 to $50^{\circ}$, secondary veins due to fragmentary preservation hardly observable, thinner, opposite, curved, venation of the higher orders poorly preserved.

Discussion: Similar fossil material has been described in Kovar-Eder et al. (2004, pl. 11, fig. 1) as Paliurus tiliifolius while Palamarev et al. (2005) interpreted such a morphotype as Cercidiphyllum macrophyllum (PALAMAREv et al. 2005 , pl. 2, fig. 2). The basal venation of the specimen at hand is similar to the leaf assigned to cf. 'Parrotia' pristina from Vrysses (ZiDianAKIs et al. 2007, fig. 2-F), which differs in the lower position of the first pair of the secondaries and is clearly coarsely dentate. In Bozukov \& Tsenov (2012), a similar morphotype from the Pontian of Bulgaria is also referred to Parrotia pristina (EtTingsh.) STUR. Among the findings from the Makrilia outcrop six leaves are referred to the Rhamnaceae as Paliurus sp. vel Zizyphus sp. vel Ceanothus sp. (SACHSE \& MoHr 1996) but they are clearly different from our material (see above under Lindera ovata).

\author{
Sapindaceae \\ Sapindus TourN. ex L. \\ Sapindus graecus UNGER \\ Figs. 4.14-4.15
}

1867 Sapindus graecus UnGER, p. 73, pl. 12, figs. 1-23.

Material: Incomplete leaflets and fragments (GAVMT 567 left, GAVMT 572 left, GAVMT 580).

Description: Leaflets with lamina asymmetric, elliptic to ovate, 45 to $68 \mathrm{~mm}$ long and 28 to $48 \mathrm{~mm}$ wide, base not always preserved, decurrent into petiolule, apex acute, margin entire; venation brochidodromous, primary vein distinct, straight, secondary veins thinner, numerous, alternate and slightly curved, at angles of 30 to $60^{\circ}$, looping several times well within the margin, tertiary veins alternate, very oblique to secondaries, sinuous, venation of the higher orders polygonal reticulate, veinlets dichotomous branching.

Discussion: This material is similar to the one described by Unger (1867) (see also KotTIs et al. 2002) from the Kymi palaeoflora as Sapindus graecus (UNGER 1867, pl. 12, figs. 3, 12). Besides the type material, foliage from the same locality ascribed to Laurus primigenia (UNGER 1867, pl. 8, fig. 5), Nephelium jovis or Eucalyptus agaea (UNGER 1867, pl. 15, fig. 1), or identified as Trigonobalanopsis rhamnoides (UNGER 1867, pl. 2, fig. 27) is hardly distinguishable. Sapindus graecus was also mentioned in Bozukov \& Tsenov (2012) for the Bulgarian palaeoflora. Thus its stratigraphic span is the Oligocene - late Miocene, while its geographic area has so far comprised the island of Euboea (UNGER 1867), Armenia and Georgia (PALiBin 1937, 1939). This finding confirms the limited distribution of this species only on the territory of southeast Europe. UNGER (1867) suggested a probable recent analogue of this fossil species to be looked for among the South African representatives of the genus but so far no

Fig. 5. 1. Acer angustilobum HeER, trilobed leaf bluntly dentate on the margin, GAVMT 515, scale bar 10 mm; 2 . Detail of medial leaf lobe's margin and venation, GAVMT 515, scale bar 5 mm; 3. Betula sp., fragmentary cuneate leaf base, GAVMT 541, scale bar $10 \mathrm{~mm}$; 4. Betula sp., incomplete leaf, GAVMT 640, scale bar $10 \mathrm{~mm}$; 5. ? Carpinus sp., complete leaf with bluntly serrate margin, GAVMT 477, scale bar $10 \mathrm{~mm}$; 6. Ulmus plurinervia UNGER, long petiolate asymmetric leaf base, GAVMT 438, scale bar 5 mm; 7. Salix cf. angusta A. BR., basal part of incomplete linear leaf, GAVMT 650, scale bar 10 $\mathrm{mm}$; 8. detail of leaf venation and margin, GAVMT 650, scale bar $5 \mathrm{~mm}$; 9. Salix cf. angusta A. BR., incomplete elliptic leaf with coarsely simply serrate margin, GAVMT 564, scale bar $10 \mathrm{~mm}$; 10. Populus populina (BRONGNIART) KNOBLOCH, complete petiolate leaf with five basal veins, GAVMT 487, scale bar $5 \mathrm{~mm}$; 11. counter-impression of Fig. 5.10, GAVMT 490, scale bar 5 mm; 12. Engelhardia orsbergensis (WeSsel \& WEBER) JäHNICHEN, MAI \& WALthER, leaflet, GAVMT 594, scale bar 5 mm; 13. Engelhardia orsbergensis (Wessel \& WeBER) JÄHNICHEN, MAI \& WALther, leaflet, GAVMT 544, scale bar $5 \mathrm{~mm}$. 

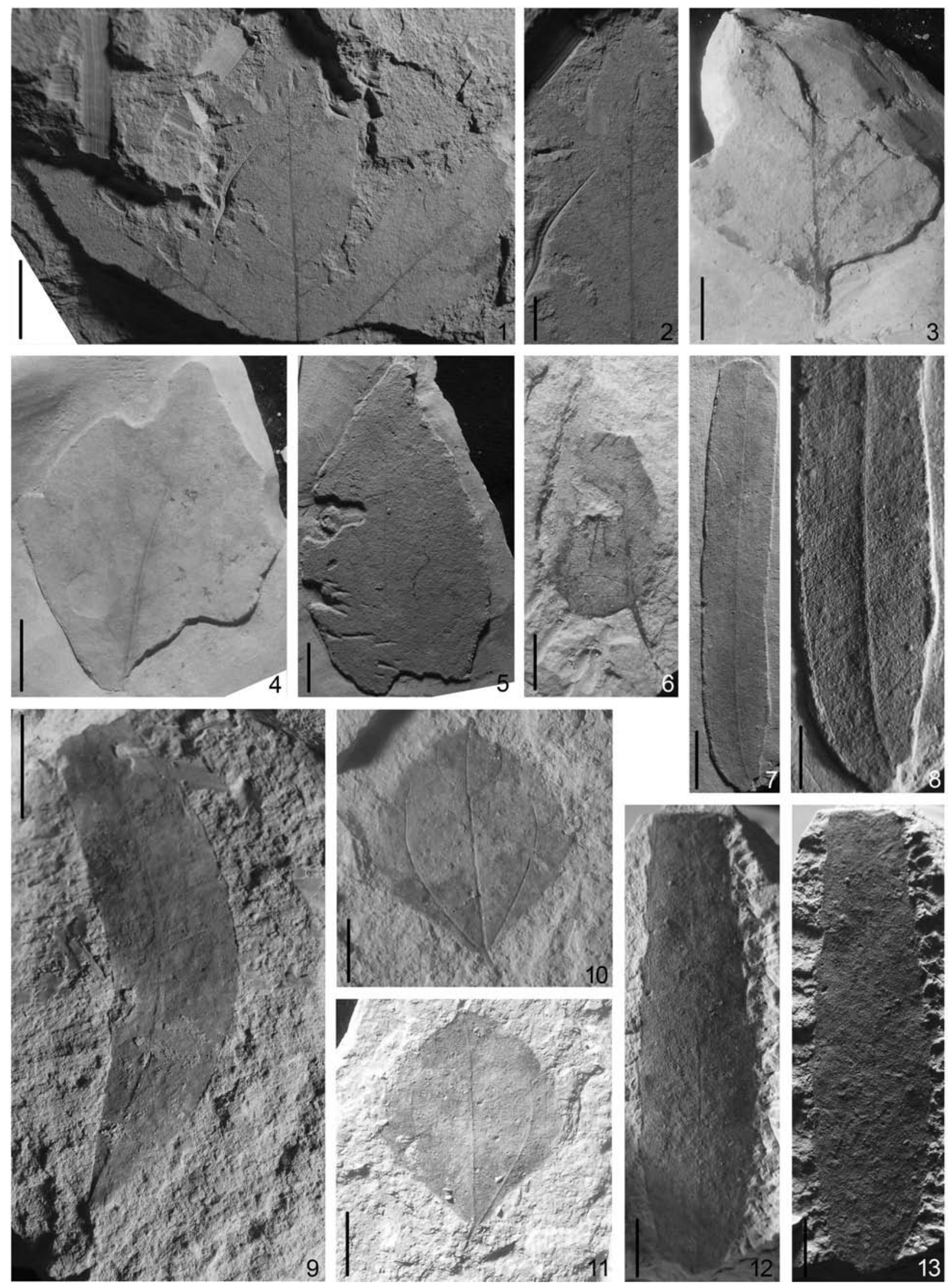

Fig. 5. 
detailed morphological study and leaf epidermal data may support this assumption.

Acer L.

\section{Acer angustilobum HeER}

Figs. 5.1-5.2

1859 Acer angustilobum HeER, p. 57, pl. 118, figs. 4-5, 7. (For further synonymy see WALTHER 1972: 40)

Material: Incomplete leaf (GAVMT 515).

Description: Only the upper part of the lamina preserved, leaf widely elliptic, palmately sub- 3-lobed, $70 \mathrm{~mm}$ long and $84 \mathrm{~mm}$ wide, lobes oblong, unevenly widely dentate at margin, apices acute to shortly accuminate, base incomplete; tooth apices acute, venation basal actinodromous, 3 primary veins, lateral veins at an angle of $30^{\circ}$ and $40^{\circ}$, straight, strong, moderately thick, secondary veins thinner, alternate, straight to curved, at angles of 30 to $50^{\circ}$, tertiary veins alternate to opposite percurrent, curved to sinuous, venation of the higher orders regular polygonal reticulate, areolation well developed, 3 to 4 sided, veinlets not visible.

Discussion: The maple foliage of such a form has been assigned to Acer angustilobum and characterized anatomically (WALther 1972, pl. 35, figs. 1, 9). A. palaeosaccharinum STUR is another similar fossil species, which differs mainly in its epidermal structure. Both fossil species are connected with transitional forms (PROCHÁzKA \& BƯŽEK 1975, as $A$. dasycarpoides). A fragment of the same morphotype was ascribed to the Vitaceae from the Makrilia flora (SACHSE \& Morr 1996, pl. 3, fig, 37; SACHSE 2004, pl. 20, fig. 1), where foliage of Acer pseudomonspessulanum ( decipiens) prevails. Similar more complete maple foliage from the Vegora flora was identified as A. subcampestre GÖPPERT (KVAČEK et al. 2002, pl. 24, fig. 6). Our material is too fragmentary and lacking epidermal characters. According to T. DENK (pers. comm. 2013) the preserved morphological features suggest Acer palaeosaccharinum rather than A. angustilobum as the most likely possibility. The Nearest Living Species of both fossil species were determined by ProcházKa (in ProcházKA \& BŮŽEK 1975) as A. saccharum MARSH. and A. saccharinum L., both native in the warm temperate Atlantic USA.

\section{Betulaceae Betula L.}

\section{Betula sp.}

Figs. 5.3-5.4

? 1964 Betula subpubescens GöPPERT; KOLAKOVsKY, p. 62 f., pl. 18 , fig. 6.

Material: Incomplete leaves (GAVMT 541, GAVMT 640).
Description: Leaves simple, lamina widely elliptic to ovate (?), $45 \mathrm{~mm}$ and $52 \mathrm{~mm}$ long, $35 \mathrm{~mm}$ and $39 \mathrm{~mm}$ wide, apex not preserved, base asymmetrical, cuneate with fragmentary $5 \mathrm{~mm}$ long petiole, margin entire basally, higher irregularly simple serrate, venation craspedodromous, midrib straight, strong, secondaries alternate, thin, regularly and coarsely spaced, at angles of 40 to $50^{\circ}$, curved, tertiary veins alternate percurrent, straight or curved, venation of the higher orders regular polygonal reticulate, poorly preserved.

Discussion: These specimens are similar to the record from the late Miocene locality Kodor in Abchasia identified as Betula subpubescens GöPpert (KolAKOvsKy 1964, pl. 18, fig. 6). The available fragments are insufficient for an exact identification or indication of related living species.

\section{Carpinus L. \\ ? Carpinus sp. \\ Fig. 5.5}

Material: Incomplete leaf (GAVMT 477).

Description: Leaf simple, lamina ovate, $76 \mathrm{~mm}$ long and $38 \mathrm{~mm}$ wide, base incomplete, probably widely cuneate to rounded, apex acute, margin damaged by preparation, probably irregularly simple serrate, venation craspedodromous, midrib straight, strong, secondaries alternate, thin, slightly curved, regularly spaced, at angles of 45 to $60^{\circ}$, tertiary veins alternate percurrent, straight or curved, rarely forked, venation of the higher orders not well preserved, probably regular polygonal reticulate.

Discussion: The single poorly preserved recovered specimen matches in overall leaf morphology foliage of Carpinus grandis UNGER, which occurs also in the flora of Vegora (KvaČEK et al. 2002, pl. 19, fig. 3). The margin is less distinctly toothed than in the better preserved material. Carpinus betulus L. is usually considered as the nearest living relative but the morphology of fruits is needed to resolve true specific affinities.

\section{Ulmaceae}

Ulmus L.

\section{Ulmus? plurinervia UNGER}

Fig. 5.6

? 1847 Ulmus plurinervia UnGER, p. 95, pl. 25, figs. 1-4.

? 1851 Planera ungeri EtTINGSHAUSEN, p. 14, pro parte, pl. 2, figs. 11-12.

(For further synonymy see Kovar-Eder et al. 2004).

Material: Incomplete leaf (GAVMT 438).

Description: Leaf simple, petiolate, lamina ovate, $30 \mathrm{~mm}$ 
long and $14 \mathrm{~mm}$ wide, base asymmetric, slightly cordate, with $5 \mathrm{~mm}$ long petiole, apex incomplete, margin double serrate, primary teeth triangular, secondary teeth finer, venation craspedodromous, midrib strong, straight, secondary veins thinner, straight or forked, distinct, alternate, opposite at the basal part, parallel, numerous, at an angle of 30 to $50^{\circ}$ (basal pair $80^{\circ}$ ), tertiary veins alternate percurrent, straight to sinuous, venation of the higher orders regular polygonal reticulate, areolation well developed, areoles 3- or 4-sided.

Discussion: This leaf fragment is similar to Ulmus plurinervia UNGER as characterized by KOVAR-EDER et al. (2004, pl. 6, fig. 21) and in KvAČEK et al. (2002: 150 f., pl. 20, fig. 12). A similar leaf identified as Fagus orientalis LIPSKY fossilis by KolaKovSKY (1964: 26, fig. 6) differs in the larger size and the dentation, which seems to go close to the base. Similar fossil leaves are also ascribed to Betula subpubescens GöPPERT (KOLAKOVSKY 1964, pl. 18, figs. 5-6) or Zelkova zelkovifolia (Unger) BŮŽEK \& Kotlaba (Telles Antunes et al. 1999, pl. 1, fig. 5). Among the findings from the Makrilia outcrop three leaves of cf. Ulmus plurinervia were described (SACHSE et al. 1999; SACHSE 2004), not quite matching our material.

\section{Salicaceae Salix L. \\ Salix cf. angusta A. BRAUN}

Figs. 5.7-5.9

Material: Incomplete leaves and fragments (GAVMT 363, GAVMT 498, GAVMT 528, GAVMT 537, GAVMT 564, GAVMT 576, GAVMT 606, GAVMT 646, GAVMT 650).

Description: Incomplete simple leaves and fragments, linear to narrow oblong, 28 to $90 \mathrm{~mm}$ long, 8 to $23 \mathrm{~mm}$ wide, base cuneate, rarely asymmetrical, apex rounded, margin entire, venation eucamptodromous, midrib strong, straight, secondary veins dense, alternate, regularly spaced, looping near margin, at angles of 40 to $80^{\circ}$, intersecondaries thin, parallel, tertiary veins alternate percurrent, straight or curved, venation of the higher orders poorly preserved, probably regular polygonal reticulate.

Discussion: Similar leaf forms are usually assigned to Salix angusta A. BR. (see HANTKE 1954: 58, pl. 6, figs. 1-4). Most of these specimens are also similar to Apocynophyllum sp. in sense of Kolakovsky (1964, pl. 7, figs. 9-12, pl. 8, fig. 1) and the others (e.g., GAVMT 537) might be similar to Nerium sp. sensu Kovar-Eder et al. (2004, pl. 11, fig. 17) but the intramarginal vein characteristic of both cases is lacking in our material. We suspect that the same morphotype from the Makrilia flora was identified as cf. Salix sp. or Myrica sp. type M. cf. lignitum by SACHSE et al. (1999, text-figs. 1.19, 1.29). Of the living willows $S$. viminalis L. is usually suggested as NLR although no detailed study has been undertaken to prove this relationship.
Populus L.

Populus populina (Brongniart) E. KNOBLOCH

Figs. 5.10-5.11

1822 Phyllites populina Brongniart, p. 237, pl. 14, fig. 4.

1850 Populus latior A. Braun. - Unger, p. 416.

1932 Populus latior A. Braun. - Konjaroff, p. 54, pl. 16, pl. 17, fig. 2; text-fig 3 .

1964 Populus populina (Brongniart). - KNOBloch, p. 601.

Material: Complete leaf and counter-impression (GAVMT 487, GAVMT 490).

Description: Leaf simple, petiolate, petiole up to $5 \mathrm{~mm}$ long, lamina widely elliptic, $28 \mathrm{~mm}$ long and $17 \mathrm{~mm}$ wide, base widely cuneate, apex widely acute to obtuse; margin regularly coarsely dentate to crenulate, teeth blunt, rounded, venation basal actinodromous, tri-veined, midrib strong, straight, lateral veins thinner, distinct, opposite, ascending towards the upper third of the lamina, at angles of $40-60^{\circ}$, higher secondaries alternate to sub-opposite originating also at angles of 40 to $60^{\circ}$, secondary veins thin, opposite to alternate, venation of the higher orders poorly preserved.

Discussion: This material showing five primary veins matches a leaf illustrated in KvAČEK et al. (2002: 152 f., pl. 21, fig.1) from the Vegora flora and assigned to Populus populi$n a$. The typical form of this species differs by the larger and broader laminae coarsely undulate at margin (HeER 1856, as Populus latior A. Braun). The existence of Populus is suggested by ZidiANAKIs et al. (2010) in the Pitsidia flora but the morphotype assigned to $P$. crenata BERGER differs from our material in coarser dentation and more numerous secondaries. In the Makrilia outcrop there are only fruits of Populus sp. among the findings (SACHSE \& MoHR 1996). According to KVAČEK et al. (2002) the Nearest Living Relative of typical Populus populina is $P$. alba, which represents a group of elements related to warm-temperate and temperate climatic conditions. P. alba is a deciduous and mesic species native to Eurasia. The recovered morphotype is also similar in leaf morphology to P. pruinosa SCHRENK. from Turkestan and NW Siberia, but no leaf epidermal evidence is available to prove this relationship.

\section{Juglandaceae \\ Engelhardia LESCHEN. ex Blume}

Engelhardia orsbergensis (WESSEL \& WEBER) JÄHNICHEN, MAI \& WALTHER

Figs. 5.12-5.13

1856 Banksia orsbergensis Wessel \& WEBER, p. 146, pl. 25, fig. 9a-d.

1977 Engelhardia orsbergensis (WESSEL \& WEBER). JäHNICHEN, MAI \& WALTHER, pp. 326-346, pls. 38-49, text-figs. 1-3. 
1984 Palaeocarya orsbergensis (WESSEL \& WEBER). JÄHNICHEN et al., p. 110.

Material: Incomplete leaflets and fragments (GAVMT 385, GAVMT 544, GAVMT 590, GAVMT 594).

Description: Isolated sessile leaflets, elongate to narrow ovate, 36 to $45 \mathrm{~mm}$ long, 8 to $9 \mathrm{~mm}$ wide, apex acute to obtuse, base mostly slightly to strongly asymmetric, rounded to widely cuneate, margin in the lower part entire, higher up simply widely serrate, teeth acute, partly S-shaped, venation camptodromous to semicraspedodromous, midrib strong, straight to slightly curved, secondary veins distinctly thinner, numerous and dense, mostly straight, alternate, at 40 to $60^{\circ}$, looping along margin, intersecondaries thinner, parallel, venation of the higher orders poorly preserved.

Discussion: This material belongs to Engelhardia orsbergensis (Wessel \& Weber) JÄHnichen, Mai \& WAlther (1977), also separated from the genus Engelhardia as Palaeocarya orsbergensis (in J̈̈HNICHEN et al. 1984 - for the nomenclature see WinTERSCHEID \& KVAČEK 2014). Among the findings from the Makrilia outcrop are similar leaflets assigned also to Palaeocarya spp. vel Myrica (SACHSE \& MoHr 1996, pl. 3, figs. 12, 17-18, 26, pl. 5, figs. 2, 7-8) or Engelhardia orsbergensis (SACHSE et al. 1999, text-figs. 1.12-1.13) matching well the Gavdos record.

Simaroubaceae

Ailanthus DESF.

\section{Ailanthus pythii (UNGER) KOVAR-EDER \& KVAČEK} Fig. 6.1

1850 Sapindus pythii Unger, p. 457 (basionym)

2004 Ailanthus pythii (Unger). - KOVAR-Eder \& KVAČEK in Kovar-Eder et al., p. 81, pl. 14, figs. 2-5.

Material: Incomplete basal part of a leaflet (GAVMT 572 right).

Description: Leaflet petiolulate, strongly asymmetrical, elliptic to ovate, base cuneate with $10 \mathrm{~mm}$ long petiolule, apex not preserved, margin in the lower part entire, higher up simply serrate, teeth acute, venation semicraspedodromous, midrib strong, curved, secondary veins thinner, curved, alternate, originating at $50^{\circ}$ to $70^{\circ}$, tertiary veins percurrent straight to sinuous, venation of the higher orders regular poorly preserved.

Discussion: This morphotype is common in the early-middle Miocene flora of Parschlug but so far not recognized in the late Miocene floras. It is the first evidence of Ailanthus in the Mediterranean area assigned to foliage. Among the findings from the Makrilia outcrop a fruit of Ailanthus sp. vel Chenopodiaceae has been described (SAchSE \& MoHR 1996), which may relate to our record.

\section{Myricaceae Myrica L. \\ Myrica lignitum (UNGER) SAPORTA \\ Figs. 6.2-6.4}

1847 Quercus lignitum UnGer, p. 113, pl. 31, figs. 5-7.

1865 Myrica lignitum (Unger) SAPORTA, p. 102.

1982 Myrica lignitum (Unger) SAPORTA. - Kovar, p. 80, pl. 12, figs. $1-8$.

1999 Myrica lignitum (Unger) SAPORTA. - SAChSE et al., p. 367, pl. 1, figs. 1.18, 1.24, 1.26, 1.29 .

(For further synonymy see Kovar 1982)

Material: Incomplete leaves and fragments (GAVMT 323, GAVMT 361, GAVMT 375, GAVMT 408, GAVMT 422, GAVMT 450, GAVMT 454, GAVMT 642).

Description: Leaves simple, petiolate, mostly incomplete, lamina oblong to elliptic or slightly obovate, 23 to $75 \mathrm{~mm}$ long and 8 to $23 \mathrm{~mm}$ wide, base often asymmetrical cuneate, rarely with up to $7 \mathrm{~mm}$ long petiole, apex incomplete probably blunt, acuminate to obtuse, margin entire or coarsely simply serrate, teeth closely spaced, blunt, venation eucamptodromous, in toothed specimens semicraspedodromous, midrib strong, straight, secondary veins thinner, looping along margin, alternate, at angles of 30 to $60^{\circ}$, rare intersecondaries thinner and parallel, venation of the higher orders poorly preserved.

Fig. 6. 1. Ailanthus pythii (UNGer) KOVAR-Eder \& KVAČEK, strongly asymmetrical leaflet base, GAVMT 572 right, scale bar $10 \mathrm{~mm}$; 2. Myrica lignitum (UNGER) SAPORTA, leaf with dentate margin, GAVMT 642, scale bar 5 mm; 3. Myrica lignitum (Unger) SAPORTA, leaf with entire margin, GAVMT 323, scale bar $10 \mathrm{~mm}$; 4. Myrica lignitum (Unger) SAPORTA, leaf with entire margin, GAVMT 619, scale bar $10 \mathrm{~mm}$; 5. Dicotylophyllum sp. 1, leaf base with serrate margin, GAVMT 584, scale bar $5 \mathrm{~mm}$; 6. Dicotylophyllum sp. 2, shortly petiolate incomplete leaf, GAVMT 648, scale bar 10 mm; 7. Dicotylophyllum sp. 2, shortly petiolate leaf, GAVMT 353, scale bar $10 \mathrm{~mm} ; 8$. Dicotylophyllum sp. 3, leaf or leaflet, GAVMT 452, scale bar $10 \mathrm{~mm}$; 9. Dicotylophyllum sp. 4, incomplete leaf with brochidodromous venation, GAVMT 336, scale bar $10 \mathrm{~mm}$; 10 . Dicotylophyllum sp. 4, incomplete leaf, GAVMT 404, scale bar $10 \mathrm{~mm}$; 11. Dicotylophyllum sp. 5, incomplete leaf, GAVMT 483, scale bar $10 \mathrm{~mm}$; 12. Dicotylophyllum sp. 5, leaf, GAVMT 582, scale bar $10 \mathrm{~mm}$; 13. Dicotylophyllum sp. 6, cuneate leaf base, GAVMT 396, scale bar $10 \mathrm{~mm}$. 

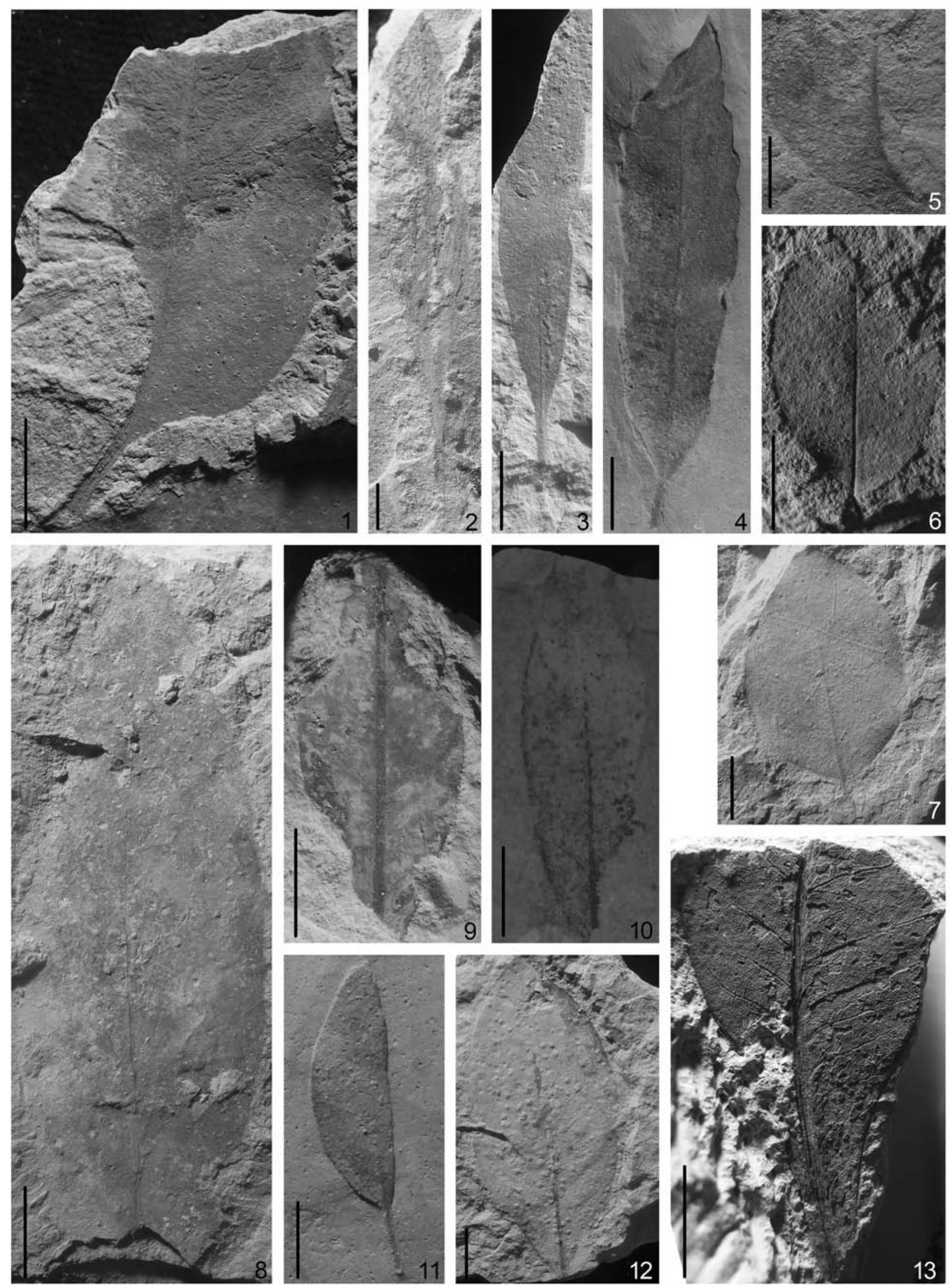

4
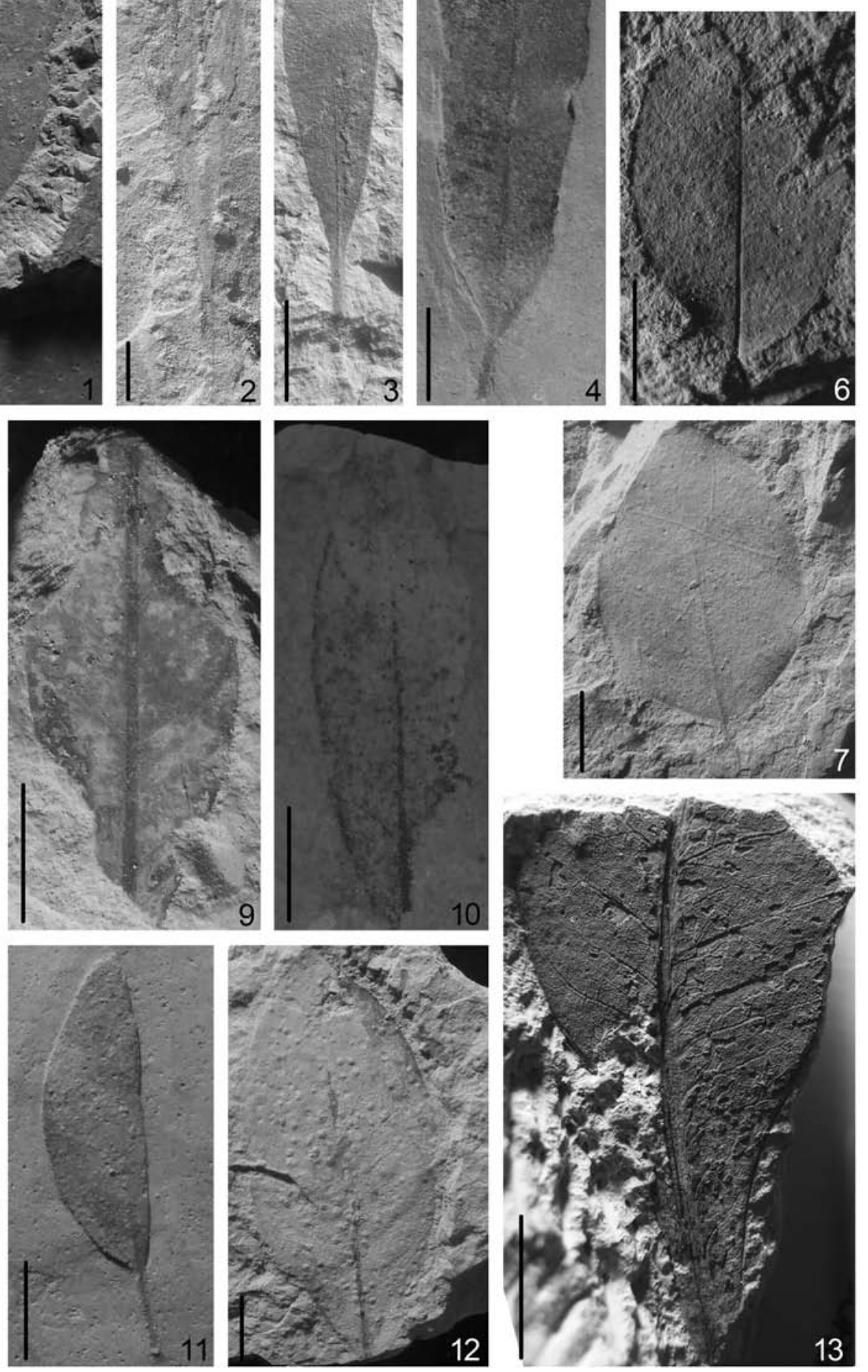

Fig. 6. 
Discussion: According to Kovar-Eder et al. (2004), at least in the plant assemblage of Parschlug, Myrica lignitum, together with Populus populina, belongs either to azonal elements or, along with Zelkova zelkovifolia, may also represent an element of mesic forests. ZIDIANAKIS et al. (2010) commented widespread occurrence of Myrica lignitum stressing optimal conditions on acidic bogs for the Pitsidia locality. In these habitats, with low nutrient supply and ground water level lying near or above the earth surface, a dense population of Myrica lignitum apparently prevailed. Representatives of this fossil species have been published as ?Salix varians GöpPERT (KOLAKOVSKY 1964, pl. 52, figs. 5-9) or Quercus neriifolia A. Braun (Kolakovsky 1964, pl. 30, figs. 2, 8-10) from the upper Miocene of Abchasia. Among the findings from the Makrilia outcrop are also leaves of Myrica type lignitum (SACHSE \& Mohr 1996; SACHSE et al. 1999; SACHSE 2004). $M$. cerifera is likely the nearest living relative species distributed on the eastern coast of $\mathrm{E}$ and SE North America.

\section{Angiospermae incertae sedis}

\section{Dicotylophyllum sp. 1 Fig. 6.5}

Material: Leaf fragment (GAVMT 584).

Description: Fragment of simple asymmetrical leaflet or leaf, probably elliptic to ovate, $20 \mathrm{~mm}$ long and $16 \mathrm{~mm}$ wide, base rounded, apex not preserved, margin simply serrate, venation semicraspedodromous, midrib strong, curved, secondary veins distinctly thinner, straight, alternate, originating at $50^{\circ}$ to $80^{\circ}$, intersecondaries thin, parallel, tertiary veins percurrent straight to sinuous, venation of the higher orders regular polygonal reticulate, areolation well developed, 3 to 4 sided, veinlets lacking.

Discussion: This specimen is similar to the material assigned to Pterocarya from Vegora (KvAčEK et al. 2002: 60, pl. 19, figs. 6-9) but is too incomplete to be reliably assigned to this genus. Foliage of this kind is unknown from the Makrilia outcrop (SACHSE \& MoHR 1996) or elsewhere in the Crete Island.

\section{Dicotylophyllum sp. 2 Figs. 6.6-6.7}

Material: Complete leaves/leaflets (GAVMT 353, GAVMT 648).

Description: Leaves or leaflets, elliptic to ovate, 38 and $45 \mathrm{~mm}$ long, 19 to $29 \mathrm{~mm}$ wide, base asymmetrical, widely cunate with petiolate/petiolulate, up to $2 \mathrm{~mm}$ long, apex rounded, margin entire, venation brochidodromous, midrib strong, straight, secondary veins thinner, looping, alternate, at angles of 70 to $85^{\circ}$, intersecondaries indistinct, thinner, parallel, venation of the higher orders are poorly preserved.

Discussion: The relationship of this type of foliage is fully uncertain.

\section{Dicotylophyllum sp. 3 \\ Fig. 6.8}

Material: Incomplete leaf (GAVMT 452).

Description: Leaf simple, elliptic, $105 \mathrm{~mm}$ long and $40 \mathrm{~mm}$ wide, base incomplete, probably cuneate to rounded, apex acute, margin simply serrate, teeth regular, acute, venation semicraspedodromous, midrib strong, straight, secondary veins, thinner, alternate to subopposite, irregularly spaced, originating at angles of 30 to $45^{\circ}$, venation of the higher orders poorly preserved.

Discussion: The single specimen of this morphotype available is similar in venation and gross morphology to the material from Kodor assigned by KoLAKOVSKY (1964) to several fossil taxa. Those assigned to Ilex simile KoLAKOvsKy seems to match best our material (KolaKovsKy 1964: 50, pl. 9, fig. 17, pl. 10, fig. 1), but some more come into question, such as Ilex raridentata KolaKovsKy (KolaKovsKy 1964, pl. 9, figs. 12-13). Arbutus elegans KolakovsKy (1964, pl. 22, figs. 9-10, pl. 13, figs. 1-5) or Carya serraefolia (GöPP.) KRÄUSEL (KolAKOVSKY 1964, pl. 37, figs. 4-5) may also come into question. None of these generic affinities can be considered unequivocal without evidence of leaf epidermal anatomy.

\section{Dicotylophyllum sp. 4 \\ Figs. 6.9-6.10}

Material: Incomplete simple leaf/leaflet and fragment (GAVMT 336, GAVMT 404 and counter-part GAVMT 463).

Description: Simple leaf (? or leaflet), elliptic, 43 and 58 $\mathrm{mm}$ long, 18 and $23 \mathrm{~mm}$ wide, base angle symmetrical, cuneate, apex round, margin entire, venation brochidodromous, midrib strong, straight, secondary veins, very thin, irregularly spaced, looping along margin, subopposite to alternate, at angles of 45 to $60^{\circ}$, intersecondaries parallel, thin, venation of the higher orders poorly preserved.

Discussion: In our opinion the generic affinity of this morphotype is equivocal and requires leaf anatomical evidence. Similar material was described from Kodor as Cotoneaster palaeobacillaris Kolakovsky (see Kolakovsky 1964, pl. 50, fig. 8), from Kymi as Copaifera kymeana UNGER (D. Velitzelos in Kottis et al. 2002, pl. 15, fig. 41, as Leguminosae leaflets), and from the Miocene of Bulgaria (PALAMAREV et al. 2005) assigned to Cotoneaster palaeobacillaris Kolak. (Kolakovsky 1964, pl. 50, fig. 8), or ?Persea (KolaKovsKy 1964, pl. 42, figs. 3, 5), ?Nectandra euxina KolaK. (KolaKovsky 1964, pl. 41, figs. 4-5) and Quercus sosnowskyi KolaK. forma macrophylla KolaK. (KolaKoVSKY 1964, pl. 34, fig. 4).

\section{Dicotylophyllum sp. 5 \\ Figs. 6.11-6.12}

Material: Incomplete simple leaves (GAVMT 483, GAVMT 582). 
Table 1. Results and predicted zonal vegetation types defined by IPR-vegetation analysis for the studied fossil sites from Greece (sensu TEODORIDIs et al. 2011a, table 8).

\begin{tabular}{|c|c|c|c|c|c|c|c|c|c|c|c|c|}
\hline \multirow[t]{2}{*}{ Localities } & \multicolumn{12}{|c|}{ IPR-vegetation results } \\
\hline & $\begin{array}{l}\% \text { of } \\
\text { BLD }\end{array}$ & $\begin{array}{l}\% \text { of } \\
\text { BLE }\end{array}$ & $\begin{array}{l}\% \text { of } \\
\text { SCL + } \\
\text { LEG }\end{array}$ & ZONPALM & $\begin{array}{l}\% \text { DRY } \\
\text { HERB }\end{array}$ & $\begin{array}{c}\% \\
\text { MESO } \\
\text { HERB }\end{array}$ & $\begin{array}{c}\% \text { of zonal } \\
\text { herbs of } \\
\text { zonal taxa }\end{array}$ & $\begin{array}{c}\text { Number } \\
\text { of zonal } \\
\text { taxa }\end{array}$ & $\begin{array}{c}\text { Number of } \\
\text { zonal woody } \\
\text { angiosperms }\end{array}$ & $\begin{array}{c}\text { Total } \\
\text { number } \\
\text { of taxa }\end{array}$ & $\begin{array}{c}\text { Problematic } \\
\text { taxa }\end{array}$ & $\begin{array}{c}\text { Vegetation type } \\
\text { sensu TEODORIDIs } \\
\text { et al. (2011a) }\end{array}$ \\
\hline Gavdos & 75.51 & 22.45 & 2.04 & 0 & 0 & 0 & 0 & 26.5 & 24.5 & 30 & 0 & BLDF/MMF \\
\hline Makrilia & 47.98 & 28.54 & 23.48 & 0 & 0 & 1.1 & 1.1 & 45 & 41 & 54 & 0 & ShSF \\
\hline Pitsidia & 53.33 & 20 & 26.67 & 0 & 0 & 2.94 & 2.94 & 17 & 15 & 22 & 0 & ShSF \\
\hline Vrysses & 40.14 & 25.85 & 34.01 & 0 & 0 & 0 & 0 & 26 & 24 & 31 & 0 & ShSF \\
\hline
\end{tabular}

Description: Leaves simple, elliptic, 90 to $94 \mathrm{~mm}$ long, 24 to $45 \mathrm{~mm}$ wide, base cuneate with petiole up to $20 \mathrm{~mm}$ long, apex acute, margin entire, venation basal actinodromous, tri-veined, midrib strong, moderate, straight, lateral veins thinner, originating at $25^{\circ}$ to $40^{\circ}$, higher secondaries brochidodromous, numerous, opposite originating also at 45 to $60^{\circ}$, intersecondaries thinner, parallel, tertiary veins opposite to alternate, percurrent, sinuous, venation of the higher orders poorly preserved.

Discussion: These two specimens are similar to entiremargined forms of Populus mutabilis HeER (1856: 19, pls. 60-62, pl. 63, figs. 1-4) from Öhningen in South Germany, particularly in the long petiole and slightly developed basal veins. The material from Kodor assigned to Hedera sp. cf. H. colchica C. Косн by Kolakovsky (1964: 54, pl. 12, figs. 3-4) is also quite similar but we doubt that it represents leaves of real Hedera. Contrary to our material, the Kodor morphotypes differ in much steeper secondaries. Regularly disposed dense secondaries seen in our material match, besides Populus mutabilis, also the venation of some Rhamnaceae, namely Berchemia (e.g., B. multinervis as illustrated in BÜŽEK 1971, pl. 32, figs.12-15, pl. 33, figs. 2223), which differs in almost sessile leaves.

\section{Dicotylophyllum sp. 6}

Fig. 6.13

Material: Leaf fragment (GAVMT 396).

Description: Leaf base $40 \mathrm{~mm}$ long, $23 \mathrm{~mm}$ wide, decurrent, texture coriaceous as shown by thick lamina, margin entire, venation eucamptodromous, midrib strong, curved, secondary veins regularly spaced, at angles of 50 to $60^{\circ}$, single intersecondaries thin, parallel with secondaries, venation of the higher orders reticulate.

Discussion: This incomplete leaf base is not determinable without epidermal characters. A similar morphotype was described from the Makrilia flora as cf. Myrtaceae gen. sp. (SAChSE et al. 1999, text-fig. 2.32; SachSe 2004, pl. 13, fig. 13). Such leaf fossils have also been compared with foliage of Periploca (e.g., Kolakovsky 1964: 124).

\section{Comparison with related fossil floras in Europe}

The Gavdos flora belongs, within the European Cenozoic system of floras composed by MAI (1995) to the Mediterranean - Tethys Bioprovince and is best included in the late Miocene floristic assemblages of Likudi - Vegora or Senigallia. This type of floras is characterized by a number of deciduous arboreal plants, particularly by Fagus gussonii, intermixed with still persisting subtropical evergreen elements. In Greece, most diversified assemblages of this type are those of Likudi and Vegora, Macedonia. Unlike the flora of Likudi composed of mostly deciduous mesic elements and lacking sclerophyllous Fagaceae (KNOBLOCH \& Velitzelos 1986), the Vegora flora (KVAČEK et al. 2002) shows several features in common with Gavdos in the spectrum of deciduous taxa, in particular Fagus gussonii, the scarcity of laurophyllous evergreen component (only rare foliage of Daphnogene and Laurophyllum) but differs in much more common sclerophyllous angiosperms (Quercus sosnowskyii, $Q$. mediterranea - drymeja complex) and in absence of Engelhardia. It is more diversified and, partly due to long-lasting collections, richer in representation of various families, e.g. Fagaceae (in particular Quercus). Similarly analogous floras of this kind occur in the Caucasus area of the Paratethys Bioprovince, namely the late Miocene flora of Kodor (KolAKOvSKY 1964). The most similar flora, also close in the geographical position and age, is that of Makrilia, Crete (MeulenKamp et al. 1979; Mohr et al. 1991; SAChSE \& Mohr 1996; Sachse 1997, 2004; SAChSe et al. 1999; Kovar-EDER et al. 2006) of late Tortonian age (8.6-7.7 Ma) sharing not only physiognomic aspects but also several important elements. A noteworthy combination of common occurrence of Taxodium, Pinus with double needled fascicles, Tetraclinis salicornioides, 
Fagus gussonii, Engelhardia orsbergensis and several further, partly enigmatic morphotypes stresses close floristic affinity of both assemblages. Less straightforward similarities are found also in the newly described localities of fossil plants from Crete, such as Vrysses (ZidiANAKIs 2002; ZidianAKIs et al. 2004, 2007) of latest Tortonian - early Messinian age (ca. 7.5-6.0 Ma), and Pitsidia, Messara Basin (ZiDIANAKIs et al. 2010) of early Tortonian age (10.5 Ma). The comparison with the Vrysses flora may suggest a closer floristic relationship, although some noteworthy plants, e.g. Bux$u s$ and Acer pseudomonspessulanum, have not been recovered at Gavdos. Due to environmental bias the recently reported Pitsidia flora shows the least common features, being dominated mainly by azonal, partly mesic deciduous elements (Pinus with fascicles of three, Myrica lignitum, Quercus roburoides, Liquidambar europaea, etc).

\section{Palaeoenvironmental analysis}

\subsection{Phytosociological approach}

The fossil plant site of Gavdos has yielded 30 taxa of higher plants: 3 conifers, 27 angiosperms and one taxon of uncertain systematic affinity. Generally, the vegetation of Gavdos is characterized by a relatively frequent occurrence of zonal elements. It is possible to distinguish three relatively specific plant assemblages based on the phytosociological approach. The plant assemblages differ in their composition (depending on specific ecological conditions of biotopes). The first plant assemblage is a mixed-swamp forest, which is typical of elements preferring an environment with relatively low dynamic (stagnant water table or periodical, relatively long-lasting floods). This vegetation type is usually typical of the marginal zone of basins or oxbow lakes in the fluvial system. These plant elements do not occur frequently in Gavdos. This vegetation type contains mainly Taxodium dubium (E4), Myrica lignitum (E2), and possibly Monocotyledonae fam. et gen. indet. (E1). The next assemblage includes plants, which permanently occupy waterlogged (wet soil) substrate. It represents a riparian assemblage containing Ulmus plurinervia (E2-3), Populus populina (E3), ?Sassafras sp. (E2), Salix cf. angusta (E2) and Monocotyledonae fam. et gen. indet. (E1). The most diversified plant assemblage that occupied upland areas is a zonal mesophytic to sclerophyllous vegetation characterized by the co- occurrence of the following elements: Pinus sp. (E3), Tetraclinis salicornoides (E2), Acer angustilobum (E2-E3), Ailanthus pythii (E4), Betula sp. (E2-3), ?Carpinus sp. (E2-3), ?Lindera ovata (E3), Laurophyllum sp. (E3), Daphnogene sp. (E3), Fagus gussonii (E3), Paliurus tiliifolius (E2), Leguminocarpon spp./Leguminosites spp. (E2-E3), Sapindus graecus (E2-3), and Engelhardia orsbergensis (E3-4). Some of the elements are difficult to interpret because of dubious taxonomic affinities (Dicotylophyllum spp.).

\subsection{IPR-vegetation analysis}

The fossil plant assemblage of Gavdos was studied using the IPR-vegetation analysis (KovAR-EDER et al. 2008; TEODORIDIs et al. 2011a) including the following characteristic key components: broad-leaved deciduous (BLD) - 75.5\%, broad-leaved evergreen (BLE) $-22.5 \%$, sclerophyllous + legume-like (SCL+LEG) $-2.04 \%$, dry herbaceous + mesophytic herbaceous / zonal herbaceous/ (D-HERB + M-HERB /ZONAL HERB/) $-0 \%$ (for a detailed taxa scoring see Table 1). According to the thresholds for the key components for defining vegetation types as detailed above (modified by TEODORIDIs et al. 2011a, table 8); the plant assemblage of Gavdos belongs to transitional vegetation (ecotone) between broad-leaved deciduous forest (BLDF) and mixed mesophytic forest (MMF). The results obtained for Gavdos can be negatively influenced by very poor preservation of the plant material, which in some cases does not permit a clear scoring into the categories of components. The IPR results obtained for the other studied Tortonian floras from Greece, namely Makrilia (SACHSE \& Mohr 1996; SACHSE et al. 1999; SAChSE 2004), Pitsidia (ZidianAKIS et al. 2010) and Vrysses (ZIDIANAKIs et al. 2007) are presented in Table 1 . There are largely dependent on the quality of taxa determination bearing some uncertainties. Generally, the plant assemblages show values of the BLD component between 40 to $53 \%$, the BLE component less than $30 \%$ and relatively high values of SCL+LEG components, exceeding $20 \%$ (Table 1). This combination of the components allows for assigning these plant assemblages to the zonal subtropical, subhumid sclerophyllous or microphyllous forest (ShSF) vegetation type sensu Kovar-Eder et al. (2008). Kovar-Eder et al. (2006, 2008) published results of IPR-vegetation analysis based on the plant material described by SACHSE et al. (1999) as follows: BLD (23\%), BLE (15\%), SCL+LEG (63\%) suggesting the same vegetation type of ShSF. The marked difference between the values of 


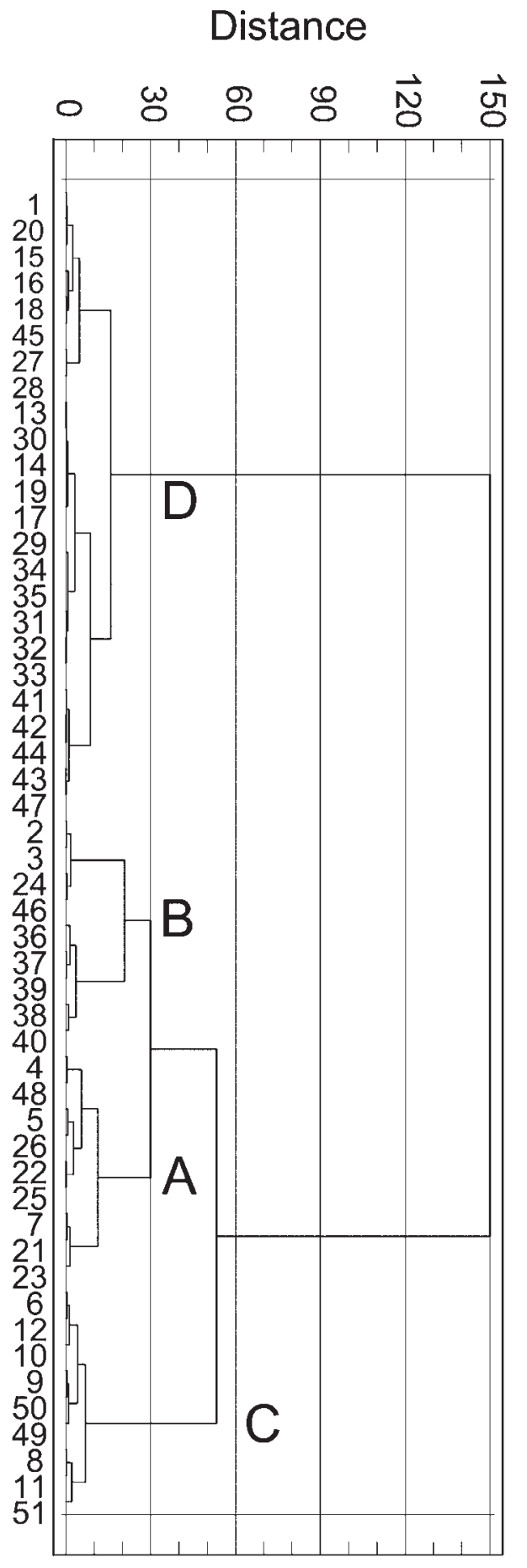

Fig. 7. Dendrogram (Ward's method, squared Euclidean distance) showing relation of the studied fossil floras from Greece to the modern tropical, subtropical and temperate vegetation types from China and Japan (sensu TEODORIDIs et al. 2011a, 2012) grouped into one cluster. Four subclusters (A to D) are distinguished. Numbers 1 to 47 represented the modern vegetation sensu TEODORIDIs et al. (2012), 48. Gavdos, 49. Makrilia, 50. Pitsidia, and 51. Vrysses. the SCL+LEG components (see Table 1) is probably due to the poor preservation of the plant material there (Kovar-Eder et al. 2006). Kovar-Eder et al. (2008) evaluated another Greek flora of Vegora, which also corresponds to the ShSF vegetation type (BLD 56\%, BLE $15 \%$, SCL+LEG 26\%). According to SAMI \& TeODORIDIS (2013), this assignment of Vegora to ShSF is very tentative, due to the lack of herbaceous elements in general (see above), which are very frequent in the modern Mediterranean floras or their equivalents in China and California (Ou et al. 2006; TANG 2006; TEODORIDIS et al. 2011a). To obtain an estimate of the diversity of herbaceous elements of the Vegora flora coeval pollen spectra would be needed.

Results of the cluster analysis (Ward's method, Euclidean square) comparing the studied Tortonian floras of Greece with 47 modern vegetation units from subtropical and tropical zones of China and Japan sensu TEODORIDIs et al. (2011a, 2012) are shown in Fig. 7. Focusing on a subcluster "A" in the dendrogram (Fig. 7), the flora of Gavdos (48) shows the closest affinity to broad-leaved deciduous vegetation of Mt. Emei in Sichuan, China (4) sensu TANG \& OHsawa (1997), moreover close relations to broad-leaved deciduous forests from the Meili Snow Mt. in Yunnan $(5,7)$, Mt. Fuji $(25,26)$ and Shirakami Sanchi area (21-23) in Japan. The vegetation units of the subcluster " $\mathrm{A}$ " show affinity to a subcluster "B", which group vegetation units of mixed mesophytic forests (MMF) from the Emei Mt. (2, 3), the Yakushima Island in Japan (Eurya-Cryptomeria japonica assoc. marked 36-40), a specific broad-leaved evergreen forest (BLEF - $\mathrm{Ca}$ mellia japonica region) from Mt. Fuji in Japan (24) and the monsoon forest in Xishuangbanna from the tropical zone of China (46). This close affinity of the subclusters A and B and plant assemblage of Gavdos corresponds to the transitional (ecotone) character of vegetation type determined by IPR vegetation analysis in Gavdos. The studied fossil plant assemblages of Makrilia, Pitsidia and Vrysses characterized with relatively high values of the SCL+LEG components are presented in a subcluster " $C$ ". The subcluster shows the closest affinity of Makrilia (49) and Pitsidia (50) and living ShSF vegetation (9) characterized by Quercus aquifolioides comm., Q. aquifolioides and Pinus armandii subcom. from the Meili Snow Mt. (Yunnan, China) sensu Ou et al. (2006). This group is closely associated with another ShSF vegetation unit (10) and summarized vegetation data of ShSF (12) from the Meili Snow Mt. and BLDF vegetation unit from the Meili Snow Mt. (6). Similarly, the studied plant as- 
semblage of Vrysses (51) is clustered with other plant communities of ShSF from the Meili Snow Mt. i.e., 11 (Quercus aquifolioides comm., Q. aquifolioides and Populus davidiana subcomm.) and 8 (Quercus guyavifolia comm.). Other living plant assemblages of broad-leaved evergreen forests (BLEF) from China and Japan and tropical vegetation from China create an isolated subcluster $\mathrm{D}$, which has no close relation to the studied fossil plant assemblage of Gavdos, Makrilia, Pitsidia and Vrysses. We have to stress that the living analogues derived from the cluster analysis may correspond to the fossil assemblages physiognomically (similar composition of the BLD, BLE, SCL+LEG components), but may not correspond to the climate conditions (e.g., areas of the Mt. Emei belonging to Cwa, and the Meili Snow Mt. to Cwb and/or Cwb $>$ Dw climate conditions of the Köppen-Geiger system (e.g., Peel et al. 2007).

The studied floras from Greece belong to the High Resolution Interval 2 (HRI 2: 8.5-12 Ma) sensu KoVAR-EDER et al. (2008), which includes about 60 sites evaluated by IPR vegetation analysis (KOVAR-EDER et al. 2008, Supplementary Data) and the European vegetation scheme are characterized during this time as follows: Broad-leaved evergreen (BLEF) and Mixed Mesophytic forests (MMF) are mostly confined to the more southern European regions and the northern parts of the Balkan Peninsula. Records from the southern parts of Europe bear higher proportions of the SCL + LEG component than those recorded from more northerly regions, such as the Lower Rhine Embayment and the Polish Lowland. Broad-leaved deciduous forests (BLDF) were widely distributed in the Molasse basin north of the Alps and the Pannonian basin, while subhumid sclerophyllous forests (ShSF) were rather scarce and largely restricted to the southern parts of Europe. The first record of xeric grasslands is available from the northern margin of the Black Sea (Kovar-EDER et al. 2008: 108). The presented high values of SCL+LEG components at the studied sites from Greece correspond and prove the mentioned high abundance of SCL+LEG elements as well as ShSF vegetation in the southeast Mediterranean, Balkan Peninsula and the Black Sea regions.

Moreover, a study on early Tortonian vegetation in Western Eurasia based on quantitative interpretation of the diversity of arboreal functional types (PFTs), carried out earlier, revealed an overall comparable pattern. There, mixed mesophytic forests of the "M3 type" (high diversity of broadleaved evergreen trees, partly sclerophyllous, with broadleaved deciduous

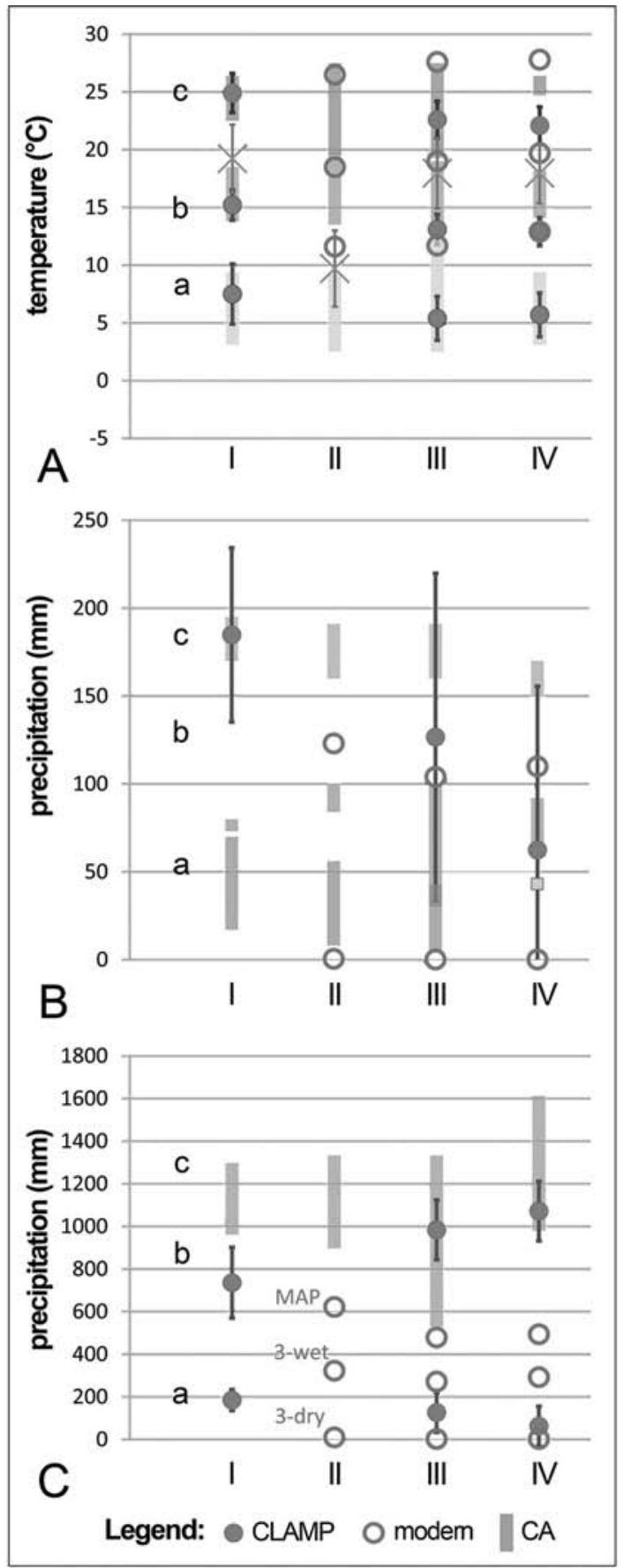

Fig. 8. Palaeoclimatic estimates for the studied floras from Greece and comparable meteorological datasets from the Crete Island. A. Temperatures with data for CMMT (a), MAT (b), and WMMT (c), $\mathrm{LMA}_{3}$ data (X) sensu Traiser et al. (2005); B. Precipitation with data for MPdry (a), MPwarm (b) and MPwet (c). Modern MPwarm and MPdry are all close to $0 \mathrm{~mm}$. CLAMP data refer to 3-DRY parameter; C. CLAMP data for 3-DRY (a) and 3-WET (b), CA data refer to MAP (c); Floras/sites: I. Gavdos, II. Pitsidia, III. Vrysses, IV. Makrilia (DATA source in Table 2). 


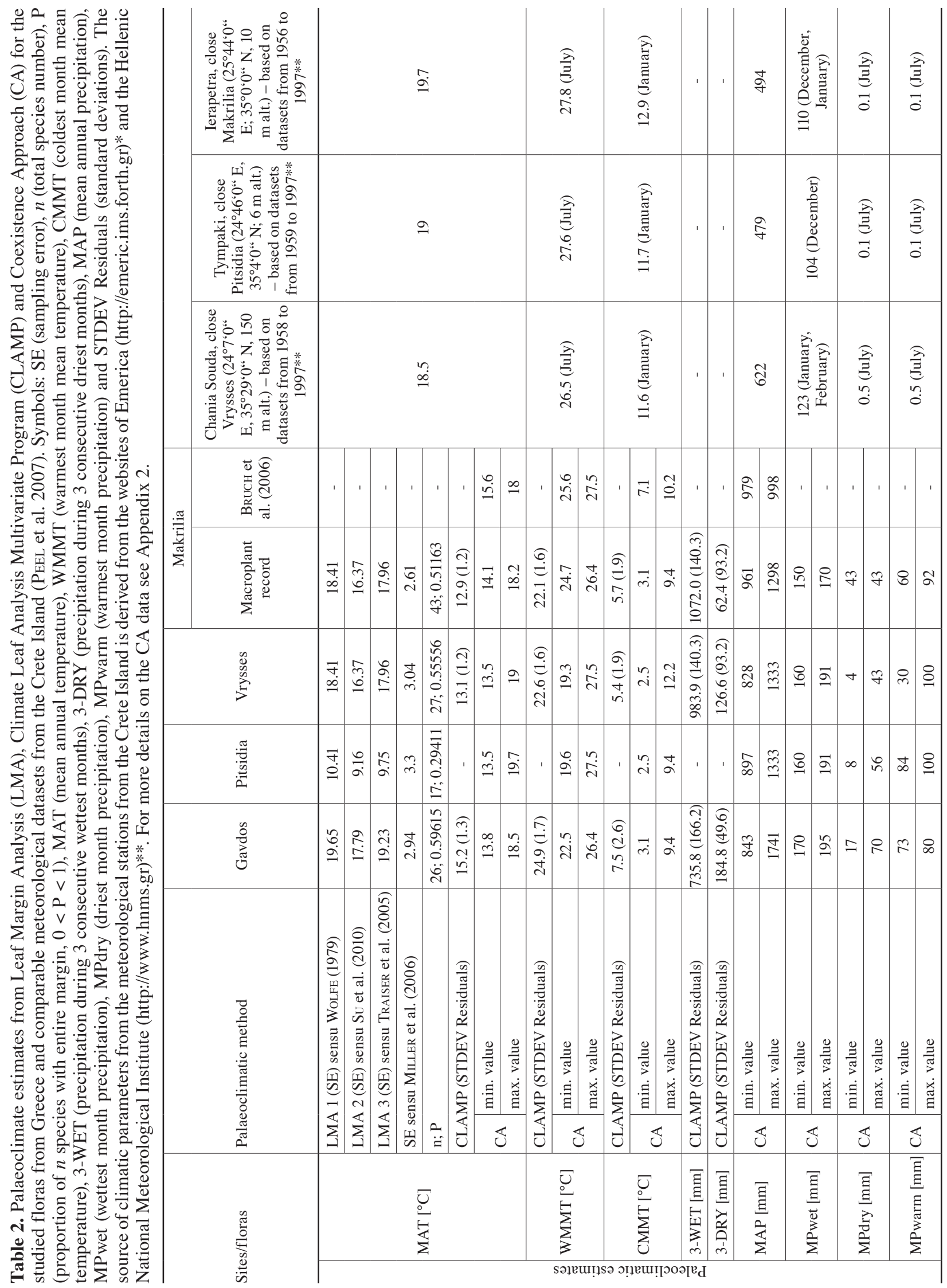


trees being the most dominant PFT, and needle-leaved PFTs present) have been described as characteristic vegetation type of the mid- and lower latitudes of the Eastern Paratethys, Black Sea coastal area, and the Eastern Mediterranean realm (UTESCHER et al. 2007). The characterization given there for the M3 type coincides well with the characterization of the zonal vegetation of Gavdos obtained when applying the phytosociological approach (see above).

\subsection{Palaeoclimate signals}

The plant assemblages from Gavdos, Vrysses, Pitsidia and Makrilia were evaluated using a combination of physiognomic (LMA, CLAMP) and taxonomic techniques (CA), based on Nearest Living Relatives. The palaeoclimate data derived from the Gavdos flora, using LMA, CLAMP and CA techniques (Table 2, Fig. 8A-C), are summarized as follows: MAT 13.8- 20 ${ }^{\circ} \mathrm{C}$, WMMT 22.5-26.4 ${ }^{\circ} \mathrm{C}$, CMMT 3.1-9. ${ }^{\circ} \mathrm{C}$, MAP 843-1741 mm, MPwet 170-195 mm, MPdry 17-70 mm. MPwarm 73-80 mm, 3-WET $735.8 \mathrm{~mm}$ (only CLAMP) and 3-DRY $184.8 \mathrm{~mm}$ (only CLAMP). The MAP and MPwarm parameters of Gavdos show relatively high values, which is in accordance with the overall mesophytic character of the vegetation (the BLDF/MMF vegetation type from IPR-vegetation analysis - see Table 1), with the lowest abundance of the SCL+LEG component (only 2\%) among the studied sites of Crete. The climatic analysis of the Gavdos flora reveals a reasonable degree in overlapping of the results obtained by different approaches when considering the standard errors (Table 2). Regarding the temperature reconstructions, the LMA data (1-3) for MAT all plot in the warmer half of the related coexistence interval while the CLAMP values are all closer to the lower temperature limits the CA suggests, or even below (MAT and WMT reconstructions for the Makrilia flora) (Fig. 8A). Regarding precipitation CLAMP and CA reconstruct different variables and consequently a direct comparison of the data is not possible. However, both methods suggest the absence of a dry summer (MPwarm $>30 \mathrm{~mm}$ ) but indicate the presence of a well expressed seasonality of precipitation (3-DRY $\sim 180 \mathrm{~mm}$; 3-WET 740 mm; MPdry < $70 \mathrm{~mm}$; MPwet $>150 \mathrm{~mm}$ ). While CLAMP and CA provide similar estimates for rainfall in the dry season, the CLAMP estimate for 3-WET suggests a considerably higher MAP compared to the CA (MAP>828 mm) when extrapolating the data.

The comparison of climate data obtained for the
Greek sites considered here reveals no significant differences in temperature based on the CA data while the results for the diverse Makrilia flora provide narrower climatic intervals and suggest a WMMT of ca. $25^{\circ} \mathrm{C}$ as probable value. LMA data for MAT are again near the warmer ends of the CA intervals except for Pitsidia where only $10{ }^{\circ} \mathrm{C}$ are estimated (LMA 1-3). These values are considered less accurate, due to a relatively low number of woody dicots in the palaeoflora (17). CLAMP derived temperatures all tend to be lower but overlap or touch the CA range, except for WMMT of the Makrilia flora where the CLAMP estimate is cooler by at least $1{ }^{\circ} \mathrm{C}$. According to CLAMP, Gavdos tends to be slightly warmer compared to Vrysses and Makrilia. Slightly different temperature values published by BRUCH et al. (2006) refer to a differing, unrevised flora list (SACHSE 1997; SACHSE \& MoHr 1996), the exclusion of Tetraclinis in the present study (cf. Appendix 4; excluded as relict), and updates in the climate database PALAEOFLORA.

Monthly precipitation rates obtained for the sites based on the CA show no significant difference, except for MPwet of Makrilia tending to be slightly lower compared to Gavdos. For Pitsidia and Vrysses, the CA derived MPdry is compatible with the existence of seasonal drought, but not in the warm season (MPwarm $>\sim 150 \mathrm{~mm}$ ). This coincides with the aforementioned higher diversity of the SCL+LEG components and predicted ShSF vegetation type based on the IPR vegetation analysis (Table 1). According to the CA, MAP was generally high $(>\sim 800 \mathrm{~mm})$, while CLAMP data point to even wetter conditions (3-WET $>\sim 600$ $\mathrm{mm})$. According to CLAMP, Gavdos had a significantly lower seasonality in precipitation compared to the floras on the mainland. Regarding the CA analysis of the Makrilia flora, the most diverse among the floras considered, no $100 \%$-overlapping of taxa ranges is obtained for some of the reconstructed climate variables. Pistacia lentiscus points to lower MPwarm compared to the majority of taxa. A possible explanation of this blurring would be mixture of floristic components from different stratigraphic levels and thus differing position in a climate cycle.

In the context of Tortonian climate patterns of western Eurasia, the sites considered here are of specific importance because they provide insight into the conditions of the lower latitudes from which only few data are currently available. In the context of published Tortonian temperature data (BRUCH et al. 2006; data compiled in Table 3) our results confirm the shallow latitudinal gradient, also expressed in the Tortonian 
Table 3. Palaeoclimate data for selected floras from the European late Miocene (Tortonian Pannonian) calculated by Coexistence Approach (CA). Symbols: MAT (mean annual temperature), WMMT (mean temperature of the warmest month), CMMT (mean temperature of the coldest month), and MAP (mean annual precipitation).

\begin{tabular}{|c|c|c|c|c|c|c|c|c|c|c|}
\hline Country & Site & $\begin{array}{c}\text { MAT min } \\
{\left[{ }^{\circ} \mathrm{C}\right]}\end{array}$ & $\begin{array}{c}\text { MAT max } \\
{\left[{ }^{\circ} \mathrm{C}\right]}\end{array}$ & $\begin{array}{c}\text { WMMT } \\
\min \\
{\left[{ }^{\circ} \mathrm{C}\right]}\end{array}$ & $\begin{array}{c}\text { WMMT } \\
\max \\
{\left[{ }^{\circ} \mathrm{C}\right]}\end{array}$ & $\begin{array}{c}\mathrm{CMMT} \\
\min \\
{\left[{ }^{\circ} \mathrm{C}\right]}\end{array}$ & $\begin{array}{c}\text { CMMT } \\
\max \\
{\left[{ }^{\circ} \mathrm{C}\right]}\end{array}$ & $\underset{[\mathrm{mm}]}{\text { MAP min }}$ & $\underset{[\mathrm{mm}]}{\text { MAP max }}$ & References \\
\hline \multirow[t]{6}{*}{ Germany } & Aubenham & 14.1 & 14.5 & 23.8 & 24.3 & 0.1 & 4.1 & 1231 & 1237 & BRUCH et al. (2006) \\
\hline & Frechen & 14 & 15.5 & 25.7 & 26.8 & 0.6 & 4.5 & 1231 & 1337 & \\
\hline & Hambach & 14.4 & 15.8 & 25.6 & 25.9 & 4.7 & 7.9 & 1231 & 1250 & \\
\hline & Klettwitz 12 & 15.7 & 16.3 & 25.7 & 25.7 & 4.7 & 6.2 & 979 & 1355 & MosBrugGer et al. (2005) \\
\hline & Leonberg & 14.4 & 17.6 & 23 & 24.9 & 2.9 & 7.6 & 735 & 1475 & BRUCH et al. (2006) \\
\hline & Massenhausen & 13.3 & 13.8 & 25.6 & 26.4 & 0 & 4,1 & - & - & BRUCH et al. (2004) \\
\hline \multirow[t]{6}{*}{ Austria } & Grossenreith & 13.6 & 15.8 & 25.7 & 27,00 & 0.6 & 4.1 & 867 & 971 & BRUCH et al. (2006) \\
\hline & Laaerberg & 13.3 & 15.7 & 25.6 & 26.4 & -0.5 & 5.1 & 897 & 1187 & \\
\hline & Lohnsburg & 13.3 & 15.8 & 25.7 & 26.4 & 0.6 & 4.1 & 897 & 971 & \\
\hline & Neuhaus & 15.6 & 15.8 & 25.3 & 26.4 & 0.6 & 5.8 & 1231 & 1355 & \\
\hline & Wien E-F & 15.7 & 16.5 & 23.8 & 27.4 & 2.9 & 6.4 & 1231 & 1355 & \\
\hline & Wörth & 13.3 & 17.3 & 25.7 & 26.7 & -0.7 & 7 & - & - & BRUCH et al. (2004) \\
\hline \multirow[t]{4}{*}{ Hungary } & Bukkabrany & 14.4 & 16.6 & 25.6 & 28.2 & 2.9 & 5.8 & 897 & 1355 & BRUCH et al. (2006) \\
\hline & Hidas & 11.6 & 18.4 & 25.6 & 26.8 & 6.2 & 7 & 1187 & 1298 & \\
\hline & Sé & 12.5 & 15.7 & 21.6 & 26.7 & -0.1 & 5.1 & - & - & BRUCH et al. (2004) \\
\hline & Visonta & 13.4 & 15.7 & 25.6 & 25.6 & 0 & 5.1 & 897 & 1206 & BRUCH et al. (2006) \\
\hline \multirow[t]{2}{*}{ Serbia } & Dubona & 14.4 & 15.4 & 26.5 & 26.7 & 3.7 & 4.8 & 1122 & 1237 & \\
\hline & Durinci & 15.6 & 16.5 & 25.7 & 26.4 & 1.8 & 4.8 & 1003 & 1237 & \\
\hline \multirow[t]{2}{*}{ Greece } & Triopetra & 15.6 & 18.4 & 24.7 & 27.8 & 5 & 9.4 & 735 & 759 & \\
\hline & Vegora & 13.3 & 14.6 & 23.8 & 24.6 & 0.4 & 4.5 & 897 & 1018 & \\
\hline \multirow[t]{2}{*}{ Romania } & Delureni & 15.6 & 18.1 & 26.5 & 27.9 & 5 & & 1122 & 1356 & \\
\hline & Oas Basin & 14.1 & 15.5 & 25.7 & 26.4 & 0.1 & 7 & 867 & 1356 & \\
\hline \multirow[t]{2}{*}{ Turkey } & Elazig Area & 15.6 & 21.3 & 24.7 & 28.1 & 5 & 13.3 & 823 & 1574 & AKGÜN et al. (2007) \\
\hline & Sivas Basin & 16.5 & 20.8 & 27.3 & 28.1 & -0.1 & 13.3 & 887 & 1520 & \\
\hline
\end{tabular}

temperature anomalies with respect to present (UTESCHER et al. 2011) where data based on sites from the higher latitudes show a temperature anomaly while values of the lower latitude sites of western Eurasia plot at the present-day level. The overall high rates of annual precipitation and rainfall in the warm season resulting for the floras support reconstructions by BRUCH et al. (2011) and QUAN et al. (2014) reporting humid summers for most sites of the Eastern Mediterranean realm, findings that clearly stand against the existence of a Mediterranean type climate at that time. Moreover, our data reveal overall consistency of data based on CA and leaf physiognomy. A similarly good agreement between CLAMP and CA in climate reconstructions for the Neogene has previously been reported from lower latitude sites in SE China (e.g., Sun et al. 2011) while estimates for sites of the middle to higher latitudes from both methods may deviate (cf. UhL et al. 2003, 2006, 2007a, b). Especially in warmer time-spans of the Neogene both approaches reveal the same trends but partly have differing absolute levels (MosBrugger \& Utescher 1997).

The aforementioned European vegetation scheme for HRI 2 (8.5-12 Ma) sensu KovAR-EDER et al. (2006, 2008) broadly coincides with the reconstructed palaeoclimatic pattern of this time period (Table 3 ). The western realm of the Paratethys, i.e., the Molasse Basin north of the Alps, and the Pannonian Basin was occupied by broad-leaved deciduous forests (BLDF). This vegetation type is indicative for temperate and humid climate conditions (Table 3). Towards the southern region of Europe (e.g., Serbia, Romania, Greece and Turkey) (AKGÜN et al. 2007) vegetation changed to more evergreen and sclerophyllous types, which were linked to warmer climates expressed by higher values of MAT, WMMT and CMMT parameters (and well comparable to our studied sites - see Tables 2 and 3, Bruch et al. 2006, figs. 2-6). On the other hand, the 
values of MAP are more or less balanced during the HRI 2 interval in Europe, which rules out a significant climate aridization in this area (BRUCH et al. 2006, fig. 6; Table 3; BRUch et al. 2011). Therefore, the slightly lower values in the precipitation of the studied Greek plant assemblages and their sclerophyllous characters as well (Tables 1-2) probably reflect specific microclimatic condition rather than a regional climatic pattern.

The leaves of beech belong to dominant and reliably established elements of the Gavdos assemblage. The stenoecious nature of Fagus (DENK \& GRIMM 2009; VelitZelos et al. 2014), requiring fully humid, Cf to Df Koeppen type climate, would suggest that this taxon thrived at higher elevations in Gavdos and not in Crete and therefore might indicate a higher elevation of the site in Gads and/or remarkably humid climatic conditions.

Present-day climate data for the studied sites are given in Table 2 and are plotted together with the reconstructed palaeoclimate data (Fig. 8A-C). It is shown that modern temperature (data are available from stations nearby Pitsidia, Vrysses and Makrilia) all are at the warm end of the CA coexistence intervals and thus close to the results obtained from LMA, or even slightly above, and significantly warmer (in the order of 7 ${ }^{\circ} \mathrm{C}$ ) than the values obtained using CLAMP. Thus it can be concluded that the elsewhere very pointed late Neogene cooling (e.g., MosBrugGer et al. 2005) hardly affected the SE Mediterranean realm. A comparable situation is reported from the lower latitudes of SE China where late Neogene Cooling was also minor but there, the interpretation is not straight forward because of tectonic uplift (YAO et al. 2011; XING et al. 2012).

The modern precipitation parameters measured at stations on Crete islands (Table 2; Fig. 8B, C) correspond to the Dry-Summer Subtropical or Mediterranean climates $(\mathrm{Csa} / \mathrm{Csb})$ of the Köppen-Geiger system, with annual precipitation rates from ca. 500-600 mm (e.g., PeEL et al. 2007, see Table 2). However, the Tortonian paleoclimatic datasets from Gavdos and Crete represent a humid subtropical climate without dry season during the warmest period (Cfa). This is evident from MPwarm data (CA) accounting for more than 50 $\mathrm{mm}$ for all sites studied (modern MPwarm at all stations: $\sim 0 \mathrm{~mm}$ ). Apart from the interpretation of MPwarm, key variable to identify Cs climates, MAP estimates from all applied methods suggest higher than modern annual rainfall ( $\sim 800-1,200 \mathrm{~mm})$. At present, the Cfa climate type is restricted to relatively small regions of Europe, e.g., the NE interior of the Iberian Peninsula, the Toulouse region in France, the Adriatic realm (coastal areas of Italy, Slovenia, and Croatia, Macedonia, Central Serbia) and the Black Sea coastal area (Bulgaria, Romania, Sochi-Russia) (PeEl et al. 2007).

\section{Conclusions}

The newly recovered late Miocene flora of Gavdos in the southernmost Europe is closely related to the adjacent sites in Crete of approximately the same age. Gavdos has more floristic affinities with coeval floras of the eastern part of the Mediterranean compared to sites in the Southwest of the European continent. It can be assumed that palaeogeographical settings (PoPOv et al. 2004, Map 8. Mid-late Miocene) rather than climatic oscillations affected the floristic differentiation in the area of SE Europe at about $8 \mathrm{Ma}$.

The present climate reconstruction reveals agreement of CLAMP and CA to a large extent. Climate data reconstructed for the Gavdos flora and the other Greek localities show no signs of distinct aridization of climate and changes towards a summer-dry ("etesian") regime. However, the possibility should be considered that the plant records in each case may represent the humid part of the Tortonian climate cycles. Tortonian temperatures estimated from a total of four megafloras of Southern Greece were about at the present-day level or even slightly below. This indicates that the global temperature decline during the late Neogene affected the study area much less, compared to the middle to higher latitudinal regions of Western Eurasia. In the context of the European data array our results show that the south-north climatic gradient across Europe was obviously much reduced compared to today.

\section{Acknowledgements}

We express sincere thanks to Dr. Hans-JoAChim Gregor, Dr. Barbara Mohr and Dr. Charalampos Fassoulas for supply of publications and to Assoc. Prof. Apostolos Alexopoulos for the information on the material from the Gavdos Island. We also thank the reviewers, Prof. Dr. Johanna Eder, Prof. Dr. Dieter Uhl and Dr. Thomas Denk, who kindly suggested several corrections that improved the first and second version of the manuscript.

This research has been co-financed by the European Union (European Social Fund - ESF) and Greek national funds through the Operational Program "Education and Lifelong Learning" of the National Strategic Reference Framework (NSRF) - Research Funding Program: THALIS - UOA - "Messinian Salinity Crisis: the greatest Mediterranean environmental perturbation and its repercussions to the biota". The second and third author received financial 
support from the Ministry of Education, Youth and Sports of the Czech Republic (projects nos J 13/98: 113100006, MSM 002162085 and PRVOUK P 44). This study is a contribution to NECLIME (www.neclime.de).

\section{References}

Akgün, F., Kayseri, M.S. \& Akkiraz, M.S. (2007): Palaeoclimatic evolution and vegetational changes during the Late Oligocene-Miocene period in the Western and Central Anatolia (Turkey). - Palaeogeography, Palaeoclimatology, Palaeoecology, 253 (1-2): 56-106.

Anastasakis, G.C. (1987): Upper Cenozoic evolution of the Gavdos Rise. - Bolletino di Oceanologia Teorica ed Applicata, 5(4): 293-304.

Anastasakis, G.C., Dermitzakis, M. \& Triantaphyllou, M. (1995): Stratigraphic Framework of the Gavdos island Neogene sediments. - Newsletters on Stratigraphy, 32: $1-15$.

Antonarakou, A. (2001): Biostratigraphic and Palaeoenvironmental interpretation in Miocene sediments of Eastern Mediterranean (Gavdos Island). - PhD Thesis, University of Athens. 178 pp. (in Greek).

Antonarakou, A. \& Drinia, H. (2003): Climatic variations during sapropel deposition in Gavdos Island, Eastern Mediterranean Sea: a key for understanding formation processes. - In: Proceedings of the 8th International Conference on Environmental Science and Technology, B, 55-62; Lemnos Island.

Antonarakou, A., Drinia, H., Tsaparas, N. \& DermitzaKIS, M.D. (2007): Micropaleontological parameters as proxies of late Miocene surface water properties and paleoclimate in Gavdos Island, eastern Mediterranean. - Geodiversitas, 29 (3): 379-399.

Angiosperm Phylogeny Group (2003): An update of the Angiosperm Phylogeny Group classification for the orders and families of flowering plants: APG II. - Botanical Journal of the Linnean Society, 141: 399-436.

Angiosperm Phylogeny Group (2009): An update of the Angiosperm Phylogeny Group classification for the orders and families of flowering plants: APG III. - Botanical Journal of the Linnean Society, 161: 105-121.

Ash, A., Ellis, B., Hickey, L.J., Johnson, K., Wilf, P. \& WING, S. (1999): Manual of Leaf Architecture - morphological description and categorization of dicotyledonous and net-veined monocotyledonous angiosperms by Leaf Architecture Working Group. - 65 pp.; Washington, DC (Smithsonian Institution).

Barrón, E. \& Diéguez, C. (1994): Neogene species of the genus Fagus L. from La Cerdaña (Lerida, Spain). Taxonomic conclusions and phylogenetic considerations. Annales del Jardín Botánico de Madrid, 52 (1): 21-32.

Bozukov, V. \& Tsenov, B. (2012): Catalogue of the Cenozoic plants of Bulgaria. - Phytologia Balcanica, 18 (3): 237-261.

Braun, A. (1845): Die Tertiär-Flora von Öhningen. - Neues Jahrbuch für Mineralogie, Geologie, Geognosie und Petrefakten-Kunde, 1845: 164-173.

Brongniart, A. (1822): Sur la classification et la distribution des vegetaux fossils en general et ceux des terrains de sediments supérieurs en particulier. - Memoirs du Museum d'Histoire Naturelle, 8: 203-240.

Bruch, A.A., Utescher, T., Alcalde Olivares, C., DolaKova, N., Ivanov, D. A \& Mosbrugger, V. (2004): Middle and Late Miocene spatial temperature patterns and gradients in Europe - preliminary results based on palaeobotanical climate reconstructions. - Courier Forschungsinstitut Senckenberg, 249: 15-27.

Bruch, A.A., Utescher, T., Mosbrugger, V., Gabrielyan, I. \& Ivanov, D.A. (2006): Late Miocene climate in the circum-Alpine realm - a quantitative analysis of terrestrial palaeofloras. - Palaeogeography, Palaeoclimatology, Palaeoecology, 238: 270-280.

Bruch, A.A., Utescher, T., Mosbrugger, V. \& NECLIME members (2011): Precipitation patterns in the Miocene of Central Europe and the development of continentality. - Palaeogeography, Palaeoclimatology, Palaeoecology, 304: 202-211.

BŮŽEK, C. (1971): Tertiary flora from the Northern part of the Pétipsy area. - Věstník Ústředního Ústavu Geologického, 36: 1-118.

BƯŽEK, Č., HolÝ, F. \& KVAČEK, Z. (1976): Tertiary flora from the Volcanogenic Series at Markvartice and Veselíčko near Česká Kamenice (České Středohoří Mts.). - Sborník geologických věd, Paleontologie, 18: 69-132.

Christenhusz, M.J.M., Reveal, J.L., Farjon, A., Gardner, M.F. Mill, R.R. \& Chase, M.W. (2011): A new classification and linear sequence of extant gymnosperms. Phytotaxa, 19: 55-70.

Denk, T. (1999a): The taxonomy of Fagus in western Eurasia, 1: Fagus sylvatica subsp. orientalis (= Fagus orientalis). - Feddes Repertorium, 110 (1-2): 177-200.

Denk, T. (1999b): The taxonomy of Fagus in western Eurasia, 2: Fagus sylvatica subsp. sylvatica. - Feddes Repertorium, 110 (5-6): 381-412.

Denk, T. (2004): Revision of Fagus from the Cenozoic of Europe and southwestern Asia and its phylogenetic implications. - Documenta naturae, 150: 1-72.

Denk, T. \& Grimm, G.W. (2009): The biogeographic history of beech trees. - Review of Palaeobotany and Palynology, 158: 83-100.

Denk, T., Grimm, G., Stögerer, K., Langer, M. \& HemleBEN, V. (2002): Differentiation of Fagus in Europe and southwestern Asia - evidence from rDNA (ITS1 and ITS2) sequences and morphological data. - Plant Systematics and Evolution, 232: 213-236.

Denk, T., Grímsson, F., Zetter, R. \& Símonarson, L.A. (2011): Late Cainozoic floras of Iceland.15 Million Years of Vegetation and Climate History in the Northern North Atlantic. - Topics in Geobiology, 35: 854 pp.; Amsterdam (Springer).

Dermitzakis, M.D. \& Georgiades-Dikeoulia, E. (1987): Biozonation of the Neogene Invertebrate Megafauna of the Hellenic area. - Annals of the Hungarian Geological Institute, 70: 126-135.

Drinia, H. (2009): Foraminiferal biofacies and paleoenvironmental implications of the Early Tortonian deposits of Gavdos Island (Eastern Mediterranean). - Revue de Micropaleontologie, 52: 15-29.

Drinia, H., Antonarakou, A., Tsaparas, N. \& Kontakiotis, G. (2007): Palaeoenvironmental conditions preceding 
the Messinian Salinity Crisis: A case study from Gavdos Island. - Geobios, 40: 251-265.

Drinia, H., Antonarakou, A., Tsaparas, N., Dermitzakis, M.D. \& Kontakiotis, G. (2004): Foraminiferal record of environmental changes: Pre-Evaporitic diatomaceous sediments from Gavdos Island, Southern Greece. - Bulletin of the Geological Society of Greece, 36: 782-791.

Drinia, H., Pomoni-Papaioannou, F., Tsaparas, N. \& AnTONARAKOU, A. (2010): Miocene scleractinian corals of Gavdos island, southern Greece: implications for tectonic control and sea-level changes. - Bulletin of the Geological Society of Greece, 43: 620-626.

Ellis, B., Daly, D.C., Hickey, L.J., Johnson, K., Mitchell, J.D., WILF, P. \& WING, S. (2009): Manual of Leaf Architecture. - 190 pp.; Cambridge, USA (Cornell University Press).

Ettingshausen, C. v. (1851): Die Tertiaer-Floren der Oesterreichischen Monarchie. 1. Fossile Flora vom Wien. Abhandlungen der kaiserlich-königlichen geologischen Reichsanstalt, 2: 1-36.

FRIIS, E.M. (1977): Leaf whorls of Cupressaceae from the Miocene Fasterholt flora, Denmark. - Bulletin of the Geological Society of Denmark, 26: 103-113.

Gaudant, J., Tsaparas, N., Antonarakou, A., Drinia, H. \& Dermitzakis, M.D. (2005): The Tortonian fish fauna of Gavdos Island (Greece). - Comptes Rendus Palevol, 4: 687-695.

Gaudant, J., Tsaparas, N., Antonarakou, A., Drinia, H., Saint-Martin, S. \& Dermitzakis, M.D. (2006): A new marine fish fauna from the pre-evaporitic Messinian of Gavdos Island (Greece). - Comptes Rendus Palevol, 5: 795-802.

Guo, S.-X., Kvaček, Z., Manchester, S.R. \& Zhou, Z-K. (2012): Ditaxocladus (extinct Cupressaceae, Cupressoideae) from the Upper Cretaceous and Paleocene of the Northern Hemisphere. - Palaeontographica, (B), 288 (5-6): 135-159.

Hably, L. (1992): Early and late Miocene Floras from the Iharosbereny-I and Tiszapalkonya-I Boreholes. - Fragmenta Mineralogica et Palaeontologica, 15: 7-40.

Hantke, R. (1954): Die fossile Flora der obermiozänen Oehninger-Fundstelle Schrotzburg (Schienerberg, SüdBaden). - Denkschriften der Schweizerischen Naturforschenden Gesellschaft, 80 (2): 17-118.

HeER, O. (1853): Übersicht der Tertiärflora der Schweiz. Mitteilungen der geologischen Gesellschaft in Wien, 3 (7): $88-153$.

HeER, O. (1856): Flora Tertiaria Helvetiae II. - 110 pp.; Winterthur (Wurster \& Co.).

HeER, O. (1859): Flora Tertiaria Helvetiae III. - 378 pp.; Winterthur (Wurster \& Co.).

Herendeen, P.S. (1992): The fossil history of the Leguminosae from the Eocene of Southeastern North America. - In: Herendeen, P.S. \& Dilcher, D.L. (Eds.): Advances in Legume Systematics: Part 4. The Fossil Record: 85160; Kew (The Royal Botanic Gardens).

Hilgen, F.J., Krijgsman, W., Langereis, C.G., Lourens, L.J., Santarelli, A. \& Zachariasse, W.J. (1995): Extending the astronomical (polarity) time scale into the Miocene. - Earth and Planetary Science Letters, 136: 495-510.
I.G.M.E. (1993): Geological Map of Greece, Gavdos Island Sheet, 1:50.000.

Ivanov, D., Utescher, T., Ashraf A.R., Mosbrugger, V., Bozukov, V., Duorgova, N. \& Slavomirova, E. (2012): Late Miocene palaeoclimate and ecosystem dynamics in southwestern Bulgaria - a study based on pollen data from the Gotse-Delchev Basin. - Turkish Journal of Earth Sciences, 21: 187-211.

JACQUes, F.M.B., ShI, G. \& WANG, W. (2011): Reconstruction of Neogene zonal vegetation in South China using the Integrated Plant Record (IPR) analysis. - Palaeogeography, Palaeoclimatology, Palaeoecology, 307: 272-284.

JÄhnichen, H., Friedrich, W.L. \& TAKÁČ, M. (1984): Engelhardioid leaves and fruits from the European Tertiary. Part II. - Tertiary Research, 6 (3): 109-134.

JäHnichen, H., MAI, D.H. \& WALther H. (1977): Blätter und Früchte von Engelhardia Lesch. ex BL. (Juglandaceae) aus dem europäischen Tertiär. - Feddes Repertorium, 88 (5-6): 323-363.

Judd, W.S., Campbell, C.S., Kellogg, E.A., Stevens, P.F. \& Donoghue, M.J. (2002): Plant systematics. A phylogenetic approach. Second Edition. - 576 pp.; Sunderland (Sinauer).

Kitanov, G. (1984): Pliocene flora composition in the Gotce Delchev region. - Fitologiya, 25: $41-70$ (in Bulgarian).

Knobloch, E. (1964): Haben Cinnammomum scheuchzeri HeER und C. polymorphum (A. Br.) HeER nomenklatorisch richtige Namen? - Neues Jahrbuch für Geologie und Paläontologie, Monatshefte, 1964: 597-603.

KNobloch, E. (1969): Tertiäre Floren von Mähren. - 200 pp.; Brno (Moravské Zemské Muzeum).

KNoBloch, E. \& KvačEK, Z. (1976): Miozäne Blätterfloren vom Westrand der Böhmischen Masse. - Rozpravy Ústředního ústavu geologického, 42: 1-131.

Knobloch, E. \& Velitzelos, E. (1986): Die obermiozäne Flora von Likudi bei Elassona/Thessalien, Griechenland. - Documenta naturae, 29: 5-20.

Kolakovsky, A.A. (1957): The first addition to the Pliocene flora of Kodor (Meore-Athara). - Trudy Sukhumskogo botanicheskogo sada, 10: 237-318 (in Russian).

Kolakovsky, A.A. (1964): A Pliocene flora of the Kodor River. - 209 pp.; Sukhumi (Georgian Academy of Sciences, Izdatel'stvo Akademii Nauk Gruzinskoŭ SSR) (in Russian).

Konjaroff, G. (1932): Die Braunkohlen Bulgariens. - 303 pp.; Pernik (Publ. State Mines) (in Bulgarian).

Kottis, T., Ionkim, C., Velitzelos, E., Kvaček, Z., Denk, T. \& Velitzelos, D. (2002): Field guide to the Neogene of the Island of Evia - Early Miocene flora of Kymi. $-6^{\text {th }}$ European Paleobotany-Palynology Conference (University of Athens), $61 \mathrm{pp}$.

Kovar, J. (1982): Eine Blätter-Flora des Egerien (Ober-Oligozän) aus marinen Sedimenten der Zentralen Paratethys im Linzer Raum (Osterreich). - Beiträge zur Paläontologie von Österreich, 9: 1-209.

Kovar-Eder, J. \& KvačEK, Z. (2003): Towards vegetation mapping based on the fossil plant record. - Acta Universitatis Carolinae, Geologica, 46 (4): 7-13.

Kovar-Eder, J. \& KvaČEK, Z. (2007): The integrated plant record (IPR) to reconstruct Neogene vegetation: the IPR-vegetation analysis. - Acta Palaeobotanica, 47 (2): 
391-418.

Kovar-Eder, J., Jechorek, H., Kvaček, Z. \& Parashiv, V. (2008): The Integrated Plant Record: an essential tool for reconstructing Neogene zonal vegetation in Europe. - Palaios, 23: 97-111.

Kovar-Eder, J., Kvaček, Z. \& Ströbitzer-Hermann, M. (2004): The Miocene Flora of Parschlug (Styria, Austria) - Revision and Synthesis. - Annalen des Naturhistorischen Museums in Wien, 105A: 45-159.

Kovar-Eder, J., Kvaček, Z., Martinetto, E. \& Roiron, P. (2006): Late Miocene to Early Pliocene vegetation of southern Europe (7-4 MA) as reflected in the megafossil plant record. - Palaeogeography, Palaeoclimatology, Palaeoecology, 238: 321-339.

KovÁts, J. (1856): Fossile Flora von Erdöbénye. - Arbeiten der Ungarischen Geologischen Gesellschaft, 1: 1-37.

Krijgsman, W., Hilgen, F.J., Langereis, C.G., Santarelli A. \& Zachariasse, W.J. (1995): Late Miocene magnetostratigraphy, biostratigraphy and cyclostratigraphy in the Mediterranean. - Earth and Planetary Science Letters, 136: 475-494.

Kunzmann, L., KvačeK, Z., Mai, D.H. \& Walther, H. (2009): The genus Taxodium (Cupressaceae) in the Palaeogene and Neogene of Central Europe. - Review of Palaeobotany and Palynology, 153: 153-183.

KVAČEK, Z. (1976): Towards nomenclatural stability of European Tertiary Conifers. - Neues Jahrbuch für Geologie und Paläontologie, Monatshefte, 1975: 284-300.

KvaČEK, Z. (1989): The fossil Tetraclinis MAST. (Cupressaceae). - Časopis Národního Muzea, 155: 45-54.

KvaČEK, Z. (2007): Do extant nearest relatives of thermophile European Cenozoic plant elements reliably reflect climatic signal? - Palaeogeography, Palaeoclimatology, Palaeoecology, 253: 32-40.

KvaČEK, Z. \& Hably, L. (1991): Notes on the Egerian stratotype flora at Eger (Wind brickyard), Hungary, Upper Oligocene. - Annales Historico-Naturales Musei Nationalis Hungarici, 83: 49-82.

KVAČEK, Z. \& KNOBLOCH, E. (1967): Zur Nomenklatur der Gattung Daphnogene Ung. und die neue Art Daphnogene pannonica sp. n. - Věstník Ústředního ústavu geologického, 41 (4): 291-294.

KvaČEK, Z., Manchester, S.R. \& Schorn, H.E. (2000): Cones, seeds, and foliage of Tetraclinis salicornioides (Cupressaceae) from the Oligocene and Miocene of Western North America: a geographic extension of the European Tertiary species. - International Journal of Plant Sciences, 161 (2): 331-344.

KvaČex, Z., Velitzelos, D. \& Velitzelos, E. (2002): Late Miocene Flora of Vegora (Macedonia, N. Greece). - 175 pp.; Athens (University of Athens, Korali Publications).

MädleR, K. \& Steffens, P. (1979): Neue Blattfloren aus dem Oligozän, Neogen und Pleistozän der Türkei. Geologisches Jahrbuch, (B), 33: 3-33.

MAI, D.H. (1963): Beiträge zur Kenntnis der Tertiärflora von Seifhennersdorf. - Jahrbuch des Staatlichen Museums für Mineralogie und Geologie Dresden, 1963: 39-114.

MAI, D.H. (1995): Tertiäre Vegetationsgeschichte Europas. - 691 pp.; Jena (G. Fischer).

Mai, D.H. \& Walther, H. (1978): Die Floren der Haselbacher Serie im Weißelster-Becken (Bezirk Leipzig,
DDR). - Abhandlungen des Staatlichen Museums für Mineralogie und Geologie zu Dresden, 28: 1-200.

Massalongo, A. (1858): Synopsis florae fossilis Senogalliensis. - 138 pp.; Verona.

Massalongo, A. \& Scarabelli, G. (1859): Studii sulla flora fossile e geologia stratigrafica del Senigalliese. - 504 pp.; Imola.

Meulenkamp, J.E., Dermitzakis, M., Georgiadou-Dikaioulia, E., Jonkers, H.A. \& Boerger, H. (1979): Field Guide to the Neogene of Crete. - 32 pp.; Athens (Publications of the Geology \& Paleontology Department, University of Athens).

Meyer, H.W. \& Manchester, S.R. (1997): The Oligocene Bridge Creek Flora of the John Day Formation, Oregon. - University of California Publications, 141: 1-195.

Miller, I.M., Brandon, M.T. \& Hickey, L.J. (2006): Using leaf margin analysis to estimate the mid-Cretaceous (Albian) paleolatitude of the Baja BC block. - Earth and Planetary Science Letters, 245: 95-114.

Mohr, B., Köhler, J. \& Adamek-Jakobs, E. (1991): A late Miocene leaf flora from southern Crete (Greece). - PanEuropean Palaeobotanical Conference Vienna 1991, Abstract Volume: 26.

Mosbrugger, V. \& Utescher, T. (1997): The coexistence approach - a method for quantitative reconstructions of Tertiary terrestrial palaeoclimate data using plant fossils. - Palaeogeography, Palaeoclimatology, Palaeoecology, 134: 61-86.

Mosbrugger, V., Utescher, T. \& Dilcher, D. (2005): Cenozoic continental climatic evolution of Central Europe. Proceedings of the National Academy of Sciences, 102 (42): 14964-14969.

Ou, X., Zhang, Z., Wang, C. \& Wu, Y. (2006): Vegetation Research in Meili Snow Mountain. - 239 pp.; Beijing (Science Press).

Palamarev, E., Usunova, K. \& Bojanova, I. (1991): Fossil Plants of Class Pinopsida from the Neogene Sediments of Satovea Graben in Rhodopes Region (Southwest Bulgaria). - Documenta naturae, 66: 1-17.

Palamarev, E., Bozukov, V., Uzunova, K., Petkova, A. \& Kitanov, G. (2005): Catalogue of the Cenozoic plants of Bulgaria (Eocene to Pliocene). - Phytologia Balcanica, 11 (3): 215-364.

Palibin, I.V. (1937): Fossil Flora of Godzersky Pass. - Trudy Botanicheskogo Instituta Akademii Nauk SSSR, 1 (4): 7-92 (in Russian).

PAlibin, I. (1939): Materials on the Tertiary flora of Armenia. - In: On the $70^{\text {th }}$ Birthday and $45^{\text {th }}$ Anniversary of Scientific Work of Academician Vladimir Leontievich Komarov, President of the Academy of Sciences USSR, 607-630 (in Russian).

Peel, M.C., Finlayson, B.L. \& McMahon, T.A. (2007): Updated world map of the Köppen-Geiger climate classification. - Hydrology and Earth System Sciences, 11 (5): 1633-1644.

Petkova, A. (1967): Paläobotanische Untersuchung des Sarmats an der unteren Strömung des Iskar-Flusses. - Izvestiya na Botanicheskiya Institut (Sofia), 17: 135-168 (in Bulgarian).

Pomoni, F., Drinia, H. \& Tsaparas, N. (2013): Palaeoecological and sedimentological characteristics of the Low- 
er Tortonian scleractinian reef corals of Gavdos Island, southern Greece. - Geobios, 46 (3): 233-241.

Popov, S.V., Rögl, F., Rozanov, A.Y., Steininger, F.F., SHCherba, I.G. \& Kovac, M. (2004): Lithological-Paleogeographic maps of Paratethys. 10 maps. Late Eocene to Pliocene. - Courier Forschungsinstitut Senckenberg, 250: $1-46$.

Postma, G., Hilgen, F.J. \& Zachariasse, W.J. (1993): Precession-punctuated growth of a late Miocene submarine-fan lobe on Gavdos (Greece). - Terra Nova, 5: 483-444.

ProcházKa, M. \& BŮŽEK, C. (1975): Maple leaves from the Tertiary of North Bohemia. - Věstník Ústředního Ústavu Geologického, 41: 7-81.

Quan, C., Liu, Y.-S.(C.) \& Utescher, T. (2014): Miocene shift of European atmospheric circulation from trade wind to westerlies. - Scientific Reports. DOI: 10.1038/ srep05660.

Raffi, I., Mozzato, C., Fornaciari, E., Hilgen, F.G. \& Rio, D. (2003): Late Miocene calcareous nannofossil biostratigraphy and astrobiochronology for the Mediterranean region. - Micropaleontology, 49 (1): 1-26.

Reveal, J.L. (2012): An outline of a classification system for extant flowering plants. - Phytoneuron, 37: 1-221.

Sachse, M. (1997): Die Makrilia-Flora (Kreta, Griechenland) - Ein Beitrag zur neogenen Klima- und Vegetationsgeschichte des östlichen Mittelmeergebietes. - Ph.D. Thesis, ETH Zurich, 311 pp.

SAchse, M. (2004): Die neogene Mega- und Mikroflora von Makrilia auf Kreta und ihre Aussagen zur Klima- und Vegetationgeschichte des östlichen Mittelmeergebietes. - Flora Tertiaria Mediterranea, 6 (12): 1-323.

Sachse, M. \& Mohr, B. (1996): An upper Miocene macro- and microflora from southern Crete (Greece), and its palaeoclimatic interpretation - Preliminary results. - Neues Jahrbuch für Geologie und Paläontologie, Abhandlungen, 200: 149-182.

Sachse, M., Mohr, B. \& Suc, J.-P. (1999): The Makriliaflora (Crete, Greece) - A contribution to the Neogene history of the climate and vegetation of the Eastern Mediterranean. - Acta Palaeobotanica, 2: 365-372.

Sami, M. \& Teodoridis, V. (2013): Gli Aspetti Paleontologici della cava di Monte Tondo: Nota Preliminare. - In: ERcolani, M., Lucci, P., Piastra, S. \& Sansavini, B. (Eds.): I gessi e la cava di Monte Tondo. Studio multidisciplinare di un'area nella vena del gesso Romagnola. Memorie dell'Istituto Italiano di Speleologia, ser. II, 26: 59-80.

SAPORTA, G. DE (1865): Études sur la vegetation du Sud-Est de la France à l'epoque tertiaire. Flore d'Armissan et de Peyriac dans le basin de Narbonne (Aude). - Annales des Sciences Naturelles Botanique, 4: 5-264.

Schenau, S.J., Antonarakou, A., Hilgen, F.J., Lourens, L.J., NiJenhuis, I.A., vAN DER WeIJden, C.H. \& ZaChARIASSE, W.J. (1999): Organic-rich layers in the Metochia section (Gavdos, Greece): evidence for a single mechanism of sapropel formation during the past $10 \mathrm{My}$. - Marine Geology, 153: 117-135.

Simonelli, V. (1894a): Appunti sul la costituzione geologica dell'isola di Candia. - Atti della reale Accademia dei Lincei, 5: 236-241.

Simonelli, V. (1894b): Appunti sopra i terreni neogenici e quaternari dell' isola di Candia. - Atti della reale Accademia dei Lincei, 5: 265-268.

SPICER, R.A. (2013): http://clamp.ibcas.ac.cn/Clampset2. html. Checked October 2013.

Spicer, R.A., Valdes, P.J., Spicer, T.E.V., Craggs, H.J., Srivastava, G., Mehrotra, R.C. \& Yang, J. (2009): New development in CLAMP: calibration using global gridded meteorological data. - Palaeogeography, Palaeoclimatology, Palaeoecology, 283: 91-98.

STERnBERG, K. V. (1823): Versuch einer geognostisch-botanischen Darstellung der Flora der Vorwelt, 1 (3): 1-39; Leipzig.

STERnBerg, K. v. (1825): Versuch einer geognostisch-botanischen Darstellung der Flora der Vorwelt, 1 (4): 1-48; Regensburg.

Su, T., Xing, Y.-W., Liu, Y-S., Jacques, F.M.B., Chen, W.Y., Huang, Y.-J. \& Zhou, Z.-K. (2010): Leaf margin analysis: A new equation from humid to mesic forests in China. - Palaios, 25: 234-238.

Sun, B.N., Wu, J.Y., Liu, Y.S., Ding, S.T., Li, X.C., XIE, S.P., YAN, D.F. \& Lin, Z.C. (2011): Reconstructing Neogene vegetation and climates to infer tectonic uplift in western Yunnan, China. - Palaeogeography, Palaeoclimatology, Palaeoecology, 304: 328-336.

TANG, C.Q. (2006): Evergreen sclerophyllous Quercus forests in northwestern Yunnan, China as compared to the Mediterranean evergreen Quercus forests in California, USA and northwestern Spain. - Web Ecology, 6: 88-101.

TANG, C.Q. \& OHSAWA, M. (1997): Zonal transition of evergreen, deciduous and coniferous forests along the altitudinal gradient on a humid subtropical mountain, Mt. Emei, Sichuan, China. - Plant Ecology, 133: 63-78.

Telles Antunes, M., Pais, J., Balbino, A., Mein, P. \& AguiLAR, J.-P. (1999): The Cristo Rei section (Lower Miocene). Distal fluviatile environments in a marine series, plants, vertebrates and other evidence, age. - Ciencias da Terra, 13: 141-155.

Teodoridis, V., Kovar-Eder, J. \& Mazouch, P. (2011a): The IPR-vegetation analysis applied to modern vegetation in SE China and Japan. - Palaios, 26 (10): 623-638.

Teodoridis, V., Kvaček, Z., Zhu, H. \& Mazouch, P. (2012): Vegetational and environmental analysis of the midlatitudinal European Eocene sites and their possible analogues in Southeastern Asia. - Palaeogeography, Palaeoclimatology, Palaeoecology, 333-334: 40-58.

Teodoridis, V., Mazouch, P., Spicer, R.A. \& Uhl, D. (2011b): Refining CLAMP - investigations towards improving the Climate Leaf Analysis Multivariate Program. - Palaeogeography, Palaeoclimatology, Palaeoecology, 299 (1-2): 39-48.

Traiser, C., Klotz, S., Uhl, D. \& Mosbrugger, V. (2005): Environmental signals from leaves - a physiognomic analysis of European vegetation. - New Phytologist, 166: 465-484.

Triantaphyllou, M.V., Tsaparas, N., Stamatakis, M. \& Dermitzakis, M.D. (1999): Calcareous nannofossil biostratigraphy and petrological analysis of the preevaporitic diatomaceous sediments from Gavdos Island, southern Creece. - Neues Jahrbuch für Geologie und Paläontologie, Monatshefte, 1999: 161-178.

Tsaparas, N. (2005): Contribution in the history of sedi- 
mentation of the marine formations from the Late Cenozoic of Gavdos Island. - PhD Thesis, Athens (University of Athens), $210 \mathrm{pp}$.

Tsaparas, N. \& Marcopoulou-Diakantoni, A. (2005): Otoliths from the Middle to Upper Miocene of the Gavdos Island (South Greece). Systematics - Paleoecology Revue de Paleobiologie, 24 (2): 617-628.

Tsaparas, N., Drinia, H., Antonarakou, A., MarcopoulouDiakantoni, A. \& Dermitzakis, M.D. (2007): Tortonian Clypeaster fauna (Echinoidea: Clypeasteroida) from Gavdos island (Greece). - Bulletin of the Geological Society of Greece, 40: 225-237.

Uhl, D., Bruch, A., Traiser, C. \& Klotz, S. (2006): Palaeoclimate estimates for the Middle Miocene Schrotzburg flora (S Germany): a multi-method approach. - International Journal of Earth Sciences, 95 (6): 1071-1085.

Uhl, D., Klotz, S., Traiser, C., Thiel, C., Utescher, T., Kowalski, E.A. \& Dilcher, D.L. (2007a): Paleotemperatures from fossil leaves - a European perspective. - Palaeogeography, Palaeoclimatology, Palaeoecology, 248: 24-31.

Uhl, D., Mosbrugger, V., Bruch, A. \& Utescher, T. (2003): Reconstructing palaeotemperatures using leaf floras case studies for a comparison of leaf margin analysis and the coexistence approach. - Review of Palaeobotany and Palynology, 126: 49-64.

Uhl, D., Traiser, C., Griesser, U. \& Denk, T. (2007b): Fossil leaves as palaeoclimate proxies in the Palaeogene of Spitsbergen (Svalbard). - Acta Palaeobotanica, 47 (1): 89-107.

Unger, F. (1847): Chloris protogaea. Beiträge zur Flora der Vorwelt. 1-10: 1-149.

UnGer, F. (1850): Genera et species Plantarum Fossilium. Sumptibus academiae caesareae scientiarum. - 1-628; Vindobonae.

UnGer, F. (1864): Sylloge plantarum fossilium II. - Denkschriften der kaiserlichen Akademie der Wissenschaften, mathematisch-naturwissenschaftliche Classe, 22: 1-36.

Unger, F. (1867): Die fossile Flora von Kumi auf der Insel Euboea. - Denkschriften der Kaiserlichen Akademie der Wissenschaften in Wien, mathematisch-naturwissenschaftliche Klasse, 27: 27-87.

Utescher, T. \& Mosbrugger, V. (2013): The Palaeoflora Database. http://www.palaeoflora.de

Utescher, T., Bruch, A.A., Micheels, A., Mosbrugger, V. \& Popova, S. (2011): Cenozoic climate gradients in Eurasia - a palaeo-perspective on future climate change? - Palaeogeography, Palaeoclimatology, Palaeoecology, 304: $351-358$.

Utescher, T., Bruch, A.A., Erdei, B., François, L., Ivanov, D., JACQUES, F.M.B., KeRN, A.K., LiU, Y.-C. (C.)., MosBRUgGer, V. \& SPICER, R.A. (2014): The Coexistence Approach - Theoretical background and practical considerations of using plant fossils for climate quantification. - Palaeogeography, Palaeoclimatology, Palaeoecology, 410: $58-73$.

Utescher, T., Duordjevic-Milutinovic, D., Bruch, A. \& Mosbrugger, V. (2007): Palaeoclimate and vegetation change in Serbia during the last $30 \mathrm{Ma}$. - Palaeogeography, Palaeoclimatology, Palaeoecology, 253: 141-152.
Velitzelos, D., Bouchal, J.M. \& Denk, T. (2014): Review of the Cenozoic floras and vegetation of Greece. - Review of Palaeobotany and Palynology, 204: 56-117.

Velitzelos, E. \& KvaČEK, Z. (1999): Review of the Late Miocene flora of Vegora, western Macedonia, Greece. - Acta Palaeobotanica, 2: 419-427.

Velitzelos, E. \& Schneider, H.E. (1977): Jungtertiäre Pflanzenfunde aus dem Becken von Vegora in WestMazedonien (Griechenland). - Annales Musei Goulandris, 3: 173-180.

ViCENTE, J.C. (1970): Etude geologique de ile de Gavdos (Grece), la plus meridional de l'Europe. - Bulletin de la Societe Geologique de France, 7 (12): 481-495.

Walther, H. (1972): Studien über tertiäre Acer Mitteleuropas. - Abhandlungen der Staatlichen Sammlungen des Museums für Mineralogie und Geologie zu Dresden, 19: 1-309.

WeBb, D.A. (1959): A physiognomic classification of Australian rain forest. - Journal of Ecology, 47: 551-570.

Wessel, P. \& Weber, O. (1856): Neuer Beitrag zur Tertiärflora der niederrheinischen Braunkohlenformation. Palaeontographica, 4: 111-130.

Wilde, V. \& Frankenhauser, H. (1998): The Middle Eocene plant taphocoenosis from Eckfeld (Eifel, Germany). Review of Palaeobotany and Palynology, 101: 7-28.

Winterscheid, H. \& KVAČEK, Z. (2014): Revision der Flora aus den oberoligozänen Seeablagerungen von Orsberg bei Unkel am Rhein (Rheinland-Pfalz). - Palaeontographica, (B), 291 (1-6): 1-83.

Wolfe, J.A. (1979): Temperature parameters of the humid to mesic forests of eastern Asia and their relation to forests of other regions of the Northern Hemisphere and Australasia. - U.S. Geological Survey, Professional Papers, 1106: 1-37.

Wolfe, J.A. \& Spicer, R.A. (1999): Fossil leaf character states: multivariate analysis. - In: JonEs, T.P. \& Rowe, N.P. (Eds.): Fossil plants and spores: modern techniques, 233-239; London (The Geological Society).

Xing, Y., Utescher, T., JACQues, F.M.B., TAO, S., LiU, Y.-S., Huang, J.-J. \& Zhou, Z.-Z. (2012): Paleoclimatic estimation reveals a weak winter monsoon in southwestern China during the late Miocene: Evidence from plant macrofossils. - Palaeogeography, Palaeoclimatology, Palaeoecology, 358-360: 19-26.

Yao, Y.-F., Bruch, A.A., Mosbrugger, V. \& Li, C.-S. (2011): Quantitative reconstruction of Miocene climate patterns and evolution in Southern China based on plant fossils. - Palaeogeography, Palaeoclimatology, Palaeoecology, 304: 291-307.

Zidianakis, G. (2002): The Late Miocene Flora of Vrysses (Western Crete-Greece). A contribution to the climate and vegetation history of Crete. - Master of Science Thesis, Irakleio (University of Crete), $118 \mathrm{pp}$.

Zidianakis, G., Iliopoulos, G. \& Fassoulas, C. (2010): A new Late Miocene plant assemblage from Messara Ba$\sin$ (Crete, Greece). - Bulletin of the Geological Society of Greece, 43(2): 781-792.

Zidianakis, G., Mohr, B.A.R. \& Fassoulas, C. (2007): A late Miocene leaf assemblage from Vrysses, western Crete, Greece, and its paleoenvironmental and paleoclimatic interpretation. - Geodiversitas, 29 (3): 351-377. 
Zijistra, G. \& Kvačen, Z. (2010): Proposal to conserve the name Cupressinocladus against Libocedrites (Fossil Coniferophyta). - Taxon, 59 (1): 11.

Manuscript received: November 15th, 2013.

Revised version accepted by the Stuttgart editor: September 12 th, 2014.

\section{Addresses of the authors:}

Dimitra Mantzouka, Nicolaos Tsaparas, Vasileios KaRAKITSIOS, National and Kapodistrian University of Athens, Faculty of Geology and Geoenvironment, Department of Historical Geology and Palaeontology, Greece;

e-mails: dmantzouka@geol.uoa.gr, ntsapar@geol.uoa.gr, vkarak@geol.uoa.gr,

Zlatko KvaČEK, Charles University in Prague, Faculty of Science, Institute of Geology and Palaeontology, Albertov 6, 12843, Prague 2, Czech Republic,

e-mail: kvacek@natur.cuni.cz,

Vasilis Teodoridis, Charles University in Prague, Department of Biology and Environmental Studies, Faculty of Education, Magdalény Rettigové 4, 11639 Prague 1, Czech Republic,

e-mail: vasilis.teodoridis@pedf.cuni.cz

Torsten Utescher, Senckenberg Research Institute, Frankfurt am Main; Steinmann Institute, University of Bonn, Nussallee 8, 53115 Bonn, Germany,

e-mail: utescher@geo.uni-bonn.de 


\section{Appendices}

Appendix 1. Percentages of foliar physiognomic characters of the studied floras.

\begin{tabular}{|c|c|c|c|c|}
\hline \multicolumn{2}{|c|}{ Foliar physiognomic characters [\%] } & \multirow{2}{*}{$\frac{\text { Gavdos }}{7.69}$} & \multirow{2}{*}{$\frac{\text { Vrysses }}{11.11}$} & \multirow{2}{*}{$\frac{\text { Makrilia }}{8.57}$} \\
\hline$\Phi$ & Lobed & & & \\
\hline 萦 & No teeth & 59.62 & 55.56 & 61.43 \\
\hline 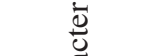 & Teeth regular & 21.15 & 33.33 & 27.14 \\
\hline ప్త్ర & Teeth close & 18.27 & 22.22 & 6.43 \\
\hline 它 & Teeth round & 20.19 & 12.96 & 7.14 \\
\hline .00 & Teeth acute & 23.08 & 31.48 & 29.29 \\
\hline$\sum$ & Teeth compound & 7.69 & 0.00 & 5.71 \\
\hline \multirow{9}{*}{ 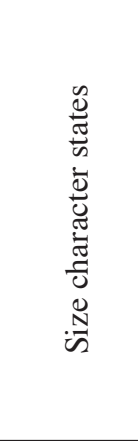 } & Nanophyll & 0.00 & 0.00 & 0.00 \\
\hline & Leptophyll I & 0.00 & 0.00 & 1.43 \\
\hline & Leptophyll II & 0.00 & 0.00 & 5.71 \\
\hline & Microphyll I & 0.00 & 20.37 & 44.29 \\
\hline & Microphyll II & 41.62 & 50.00 & 28.57 \\
\hline & Microphyll III & 29.42 & 25.93 & 17.14 \\
\hline & Mesophyll I & 27.50 & 3.70 & 2.86 \\
\hline & Mesophyll II & 1.27 & 0.00 & 0.00 \\
\hline & Mesophyll III & 0.00 & 0.00 & 0.00 \\
\hline \multirow{4}{*}{ 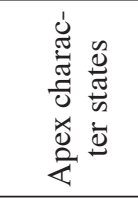 } & Apex emarginate & 0.00 & 0.00 & 1.43 \\
\hline & Apex round & 34.23 & 49.37 & 27.14 \\
\hline & Apex acute & 55.96 & 45.67 & 62.86 \\
\hline & Apex attenuate & 9.81 & 4.93 & 8.57 \\
\hline \multirow{3}{*}{ 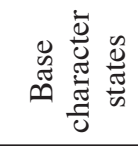 } & Base cordate & 1.92 & 18.52 & 10.00 \\
\hline & Base round & 40.38 & 35.19 & 47.14 \\
\hline & Base acute & 57.69 & 46.30 & 42.86 \\
\hline \multirow{5}{*}{ 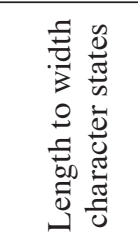 } & $\mathrm{L}: \mathrm{W}<1: 1$ & 0.00 & 9.26 & 4.29 \\
\hline & L:W 1-2:1 & 18.58 & 11.11 & 8.57 \\
\hline & L:W 2-3:1 & 26.27 & 20.37 & 28.57 \\
\hline & L:W 3-4:1 & 44.54 & 46.30 & 44.29 \\
\hline & L:W > 4:1 & 10.58 & 12.96 & 14.29 \\
\hline \multirow{3}{*}{ 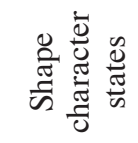 } & Obovate & 4.62 & 16.67 & 15.23 \\
\hline & Elliptic & 39.23 & 55.56 & 40.94 \\
\hline & Ovate & 56.15 & 27.78 & 43.80 \\
\hline
\end{tabular}


Appendix 2. Fossil taxa, nearest living relatives and climate date used in the Coexistence Approach (CA).

CA results Pitsidia

\begin{tabular}{|c|c|c|c|c|c|c|c|c|c|c|c|c|c|c|c|}
\hline fossil taxon & reference taxa & MATmin & MATmax & CMTmin & CMTmax & WMTmin & WMTmax & MAPmin & MAPmax & $\begin{array}{l}\text { MPwet } \\
\text { min }\end{array}$ & $\begin{array}{l}\text { MPwet } \\
\max \end{array}$ & $\begin{array}{l}\text { MPdry } \\
\text { min }\end{array}$ & $\begin{array}{l}\text { MPdry } \\
\max \end{array}$ & $\begin{array}{l}\text { MPwarm } \\
\text { min }\end{array}$ & $\begin{array}{l}\text { MPwarm } \\
\text { max }\end{array}$ \\
\hline Acer pseudomonspessulanum & Acermonspessulanum. & 9.6 & 20.5 & 0.2 & 13.6 & 18.4 & 27.5 & 399 & 1333 & 77 & 191 & 0 & 85 & 0 & 100 \\
\hline Buxus pliocaenica & Buxus sp................. & 9.7 & 25.3 & -1.2 & 20 & 17.3 & 29.4 & 399 & 2540 & 80 & 566 & 0 & 56 & 0 & 252 \\
\hline Carya minor & Carya sp.............. & 4.4 & 26.6 & -11.5 & 22.2 & 19.3 & 30.6 & 373 & 1724 & 68 & 434 & 8 & 93 & 45 & 258 \\
\hline Comptonia difformis & Comptonia peregrina. & relict & & & & & & & & & & & & & \\
\hline Cupressaceae & Cupressaceae......... & -15.6 & 26.5 & -48.9 & 26.1 & 11.2 & 32.9 & 184 & 4486 & 22 & 409 & 0 & 326 & 0 & 378 \\
\hline Daphnogene polymorpha & Cinnamomum camphora & 13.5 & 27.2 & 2.5 & 26.1 & 18.6 & 31.7 & 828 & 10798 & 160 & 2446 & 3 & 135 & 30 & 1100 \\
\hline Equisetum sp. & Equisetum sp......... & unspecific & & & & & & & & & & & & & \\
\hline Fagus gussonii & Fagus sylvatica ssp. orientalis * & 5.9 & 19.7 & -5 & 9.4 & 17.1 & 31.7 & 376 & 2115 & 46 & 195 & 5 & 94 & 5 & 195 \\
\hline Leguminosae & Leguminosae........... & -7.7 & 27.7 & -22.7 & 25.9 & 10.5 & 28.1 & 224 & 3905 & 46 & 610 & 0 & 196 & 1 & 221 \\
\hline Liquidambar europaea & Liquidambar styr.or & 12.5 & 21.3 & -0.1 & 16.3 & 19.6 & 28.6 & 897 & 1613 & 106 & 265 & 2 & 93 & 84 & 195 \\
\hline Myrica lignitum & Myrica sp................ & -8.9 & 28.1 & .29 & 27 & 8.9 & 33.9 & 233 & 3151 & 34 & 508 & 0 & 165 & 0 & 221 \\
\hline Pinus sp. & Pinus sp.............. & -9.2 & 25.5 & -36.8 & 21.4 & 7.1 & 32.9 & 180 & 10798 & 28 & 2446 & 0 & 94 & 0 & 1100 \\
\hline Poaceae vel Cyperaceae & Poaceae............... & unspecific & & & & & & & & & & & & & \\
\hline Podocarpium podocarpum & Leguminosae.......... & -7.7 & 27.7 & -22.7 & 25.9 & 10.5 & 28.1 & 224 & 3905 & 46 & 610 & 0 & 196 & 1 & 221 \\
\hline Populus crenata & Populus sp................ & -16 & 26 & -49 & 13.6 & 9.8 & 35.6 & 25 & 2559 & 8 & 358 & 0 & 93 & 0 & 224 \\
\hline Quercus drymeja & Quercus sect. Cerris & 4.7 & 22.2 & -8.7 & 15.6 & 11.7 & 28.6 & 470 & 3000 & 48 & 2695 & 0 & 85 & 0 & 1781 \\
\hline Quercus ? kubinyi & Quercus sect. Cerris & 4.7 & 22.2 & -8.7 & 15.6 & 11.7 & 28.6 & 470 & 3000 & 48 & 2695 & 0 & 85 & 0 & 1781 \\
\hline Quercus mediterranea & Quercus sect. Cerris & 4.7 & 22.2 & -8.7 & 15.6 & 11.7 & 28.6 & 470 & 3000 & 48 & 2695 & 0 & 85 & 0 & 1781 \\
\hline Quercus roburoides & Quercus sp.................. & -1.4 & 27 & -25.1 & 25.9 & 8.4 & 28.3 & 201 & 10798 & 33 & 2446 & 0 & 180 & 5 & 1100 \\
\hline \multirow[t]{4}{*}{ Zelkova zelkovaefolia } & Zelkova sp........... & 6.2 & 21.9 & -12.8 & 13.6 & 19.4 & 29.7 & 246 & 2648 & 46 & 370 & 3 & 67 & 3 & 344 \\
\hline & taxa with climate data & 19 & & & & & & & & & & & & & \\
\hline & coexistence intervals & 13.5 & 19.7 & 2.5 & 9.4 & 19.6 & 27.5 & 897 & 1333 & 160 & 191 & 8 & 56 & 84 & 100 \\
\hline & coexisting taxa (\%) & & 100 & & 100 & & 100 & & 100 & & 100 & & 100 & & 100 \\
\hline
\end{tabular}

\section{CA results Makrilia}

\begin{tabular}{|c|c|c|c|c|c|c|c|c|c|c|c|c|c|c|c|}
\hline fossil taxon & reference taxa & MATmin & MATmax & CMTmin & CMTmax & WMTmin & WMTmax & MAPmin & MAPmax & $\begin{array}{l}\text { MPwet } \\
\text { min }\end{array}$ & $\begin{array}{l}\text { MPwet } \\
\text { max }\end{array}$ & $\begin{array}{l}\text { MPdry } \\
\text { min }\end{array}$ & $\begin{array}{l}\text { MPdry } \\
\text { max }\end{array}$ & $\begin{array}{l}\text { MPwarm } \\
\text { min }\end{array}$ & $\begin{array}{l}\text { MPwarm } \\
\text { max }\end{array}$ \\
\hline Acer angustilobum & Acer sect. Acer & 2.7 & 24 & -15.6 & 20.6 & 16.2 & 28.6 & 115 & 2559 & 19 & 370 & 1 & 135 & 1 & 366 \\
\hline Acer pseudomonspessulanum & Acer monspessulanum. & 9.6 & 20.5 & 0.2 & 13.6 & 18.4 & 27.5 & 399 & 1333 & 77 & 191 & 0 & 85 & 0 & 100 \\
\hline Ailanthus sp. & Ailanthus sp......... & 6.9 & 26.7 & -8.1 & 25.3 & 18.3 & 28.9 & 376 & 3459 & 92 & 638 & 1 & 119 & 73 & 304 \\
\hline Aquilaria sp. & Aquilaria sp......... & 13.8 & 27.7 & -0.5 & 27 & 24.7 & 28.1 & 578 & 3151 & 116 & 389 & 5 & 165 & 89 & 221 \\
\hline Berberis, Mahonia & Berberis, Mahonia & -4.9 & 27.7 & -32.4 & 27 & 15 & 28.1 & 304 & 3151 & 45 & 454 & 0 & 165 & 1 & 224 \\
\hline Buxus pliocaenica & Buxus sp................. & 9.7 & 25.3 & -1.2 & 20 & 17.3 & 29.4 & 399 & 2540 & 80 & 566 & 0 & 56 & 0 & 252 \\
\hline Carpinus orientalis foss. & Carpinus orientalis. & 7.7 & 18.3 & -5.3 & 10.9 & 18.6 & 27.6 & 402 & 1548 & 71 & 191 & 3 & 82 & 3 & 122 \\
\hline Carya sp. & Carya sp.............. & 4.4 & 26.6 & -11.5 & 22.2 & 19.3 & 30.6 & 373 & 1724 & 68 & 434 & 8 & 93 & 45 & 258 \\
\hline Cladrastis sp. & Cladrastis lutea.... & 8.7 & 21.3 & -3.9 & 13.3 & 21.6 & 29.4 & 776 & 1613 & 74 & 196 & 41 & 93 & 49 & 196 \\
\hline Cymodocea sp. vel Posidonia sp. & Cymodocea sp. vel Posidonia sp. & nodata & & & & & & & & & & & & & \\
\hline Cyperaceae gen. & Cyperaceae............ & unspecific & & & & & & & & & & & & & \\
\hline Dalbergia sp. & Dalbergia sp.......... & 12 & 28.1 & -1.2 & 27 & 21.4 & 35.3 & 631 & 3151 & 111 & 554 & 1 & 165 & 20 & 462 \\
\hline Daphnogene sp. & Lauraceae............. & 4.4 & 28.1 & -16.8 & 27 & 19.3 & 30.1 & 191 & 10798 & 56 & 2446 & 0 & 165 & 0 & 1100 \\
\hline Elaeagnus sp. & Elaeagnus sp......... & -0.4 & 27.7 & -24.2 & 27 & 18.2 & 28.5 & 84 & 3151 & 28 & 389 & 2 & 165 & 13 & 221 \\
\hline Engelhardia sp. & Engelhardtia sp..... & 13.8 & 27 & 3.1 & 25 & 20.6 & 33.6 & 800 & 10798 & 150 & 2446 & 5 & 152 & 79 & 1100 \\
\hline Equisetum sp. & Equisetum sp.......... & unspecific & & & & & & & & & & & & & \\
\hline Ericaceae vel Myrtaceae & & unspecific & & & & & & & & & & & & & \\
\hline Fagus gussonii & Fagus sylvatica ssp. orientalis ". & 5.9 & 19.7 & -5 & 9.4 & 17.1 & 31.7 & 376 & 2115 & 46 & 195 & 5 & 94 & 5 & 195 \\
\hline Laurophyllum sp. & Lauraceae............. & 4.4 & 28.1 & -16.8 & 27 & 19.3 & 30.1 & 191 & 10798 & 56 & 2446 & 0 & 165 & 0 & 1100 \\
\hline Leguminosae & Leguminosae.......... & -7.7 & 27.7 & .22 .7 & 25.9 & 10.5 & 28.1 & 224 & 3905 & 46 & 610 & 0 & 196 & 1 & 221 \\
\hline Leguminosites sp. & Leguminosae........... & -7.7 & 27.7 & -22.7 & 25.9 & 10.5 & 28.1 & 224 & 3905 & 46 & 610 & 0 & 196 & 1 & 221 \\
\hline Lonicera Typ etrusca & Lonicera etrusca.... & 10.4 & 21.4 & -1.7 & 13.9 & 19.8 & 28.3 & 461 & 1298 & 70 & 198 & 1 & 56 & 2 & 60 \\
\hline Magnolia sp. & Magnolia sp........... & 4.1 & 27 & -10.2 & 25.9 & 17.1 & 28.6 & 578 & 3500 & 102 & 610 & 1 & 180 & 70 & 462 \\
\hline Myrica lignitum & Myrica sp............. & -8.9 & 28.1 & -29 & 27 & 8.9 & 33.9 & 233 & 3151 & 34 & 508 & 0 & 165 & 0 & 221 \\
\hline Myrtaceae & Myrtaceae............. & 11.3 & 27.7 & 0.1 & 27 & 18.8 & 28.1 & 250 & 3151 & 30 & 389 & 0 & 165 & 0 & 221 \\
\hline Phillyrea sp. & Phillyrea sp........ & 9.3 & 20.5 & 1 & 17.8 & 17.9 & 29.7 & 160 & 1356 & 20 & 170 & 2 & 71 & 2 & 92 \\
\hline Pinus cf. hampeana & Pinus thunbergiana.. & 9.4 & 19.2 & -1.6 & 11.4 & 20.9 & 26.9 & 631 & 1724 & 177 & 258 & 6 & 43 & 118 & 258 \\
\hline Pinus cf. hepios & Pinus sp.................. & -9.2 & 25.5 & -36.8 & 21.4 & 7.1 & 32.9 & 180 & 10798 & 28 & 2446 & 0 & 94 & 0 & 1100 \\
\hline Pinus sp. & Pinus sp.............. & -9.2 & 25.5 & -36.8 & 21,4 & 7.1 & 32.9 & 180 & 10798 & 28 & 2446 & 0 & 94 & 0 & 1100 \\
\hline Pistacia lentiscus foss. & Pistacia lentiscus.. & 12 & 19.9 & -0.4 & 12.6 & 22.3 & 28.8 & 187 & 1298 & 40 & 198 & 0 & 43 & 0 & 49 \\
\hline Podocarpium podocarpum & Leguminosae.......... & -7.7 & 27.7 & -22.7 & 25.9 & 10.5 & 28.1 & 224 & 3905 & 46 & 610 & 0 & 196 & 1 & 221 \\
\hline Populus sp & Populus sp............ & -16 & 26 & -49 & 13.6 & 9.8 & 35.6 & 25 & 2559 & 8 & 358 & 0 & 93 & 0 & 224 \\
\hline Potamogeton sp. & Potamogeton sp....... & -15 & 23.5 & -41.4 & 23 & 10.2 & 28.2 & 114 & 2648 & 15 & 448 & 0 & 157 & 0 & 431 \\
\hline Quercus drymeja & Quercus sect. Cerris & 4.7 & 22.2 & -8.7 & 15.6 & 11.7 & 28.6 & 470 & 3000 & 48 & $3 \quad 2695$ & 0 & 85 & 0 & 1781 \\
\hline Quercus kubinyi & Quercus sect. Cerris & 4.7 & 22.2 & -8.7 & 15.6 & 11.7 & 28.6 & 470 & 3000 & 48 & 2695 & 0 & 85 & 0 & 1781 \\
\hline Quercus cf. mediterranea & Quercus sect. Cerris & 4.7 & 22.2 & -8.7 & 15.6 & 11.7 & 28.6 & 470 & 3000 & 48 & 32695 & 0 & 85 & 0 & 1781 \\
\hline Quercus cf. rhenana & Quercus imbric, laur & 3.3 & 25 & -11.3 & 17.9 & 14.9 & 31.2 & 180 & 1613 & 30 & 195 & 0 & 93 & 7 & 195 \\
\hline Ruppia sp. (cf.) & Ruppia sp............. & unspecific & & & & & & & & & & & & & \\
\hline Smilax sp. (cf.) & Smilax sp.............. & -1.1 & 27.7 & -25.8 & 27 & 15.1 & 33.1 & 37 & 10798 & 8 & 2446 & 0 & 165 & 0 & 1100 \\
\hline Symplocos minutula & Symplocos tinctoria. & 13.6 & 21.1 & 2.7 & 13.3 & 23.6 & 28.9 & 961 & 1355 & 109 & 195 & 43 & 63 & 85 & 195 \\
\hline Taxodium dubium & Taxodium sp........... & 13.3 & 25 & -0.1 & 19.8 & 18.9 & 31.2 & 290 & 2615 & 60 & 265 & 0 & 93 & 19 & 227 \\
\hline Tetraclinis salicornoides & Tetraclinis (articul & relict & & & & & & & & & & & & & \\
\hline Tilia sp. & Tilia sp............... & 1.3 & 22.2 & -17.7 & 15.1 & 15 & 29.4 & 373 & 2336 & 68 & 454 & 3 & 95 & 15 & 258 \\
\hline Toddalia sp. & Toddalia sp. (monoty & 14.1 & 27.3 & -1.4 & 25 & 20.6 & 31.7 & 693 & 10798 & 135 & 2446 & 1 & 70 & 20 & 1100 \\
\hline Uimus sp. & Ulmus sp............. & -4.9 & 26.6 & -25.8 & 26.1 & 16 & 29.4 & 201 & 3285 & 33 & 569 & 0 & 100 & 0 & 239 \\
\hline \multirow[t]{4}{*}{ Zelkova zelkova efolia } & Zelkova sp........... & 6.2 & 21.9 & -12.8 & 13.6 & 19.4 & 29.7 & 246 & 2648 & 46 & 370 & 3 & 67 & 3 & 344 \\
\hline & taxa with climate data & 45 & & & & & & & & & & & & & \\
\hline & coexistence intervals & 14.1 & 18.2 & 3.1 & 9.4 & 24.7 & 26.4 & 961 & 1298 & 150 & 170 & 43 & 43 & 60 & 92 \\
\hline & coexisting taxa (\%) & & 100 & & 100 & & 100 & & 100 & & 97.8 & & 100 & & 97.8 \\
\hline
\end{tabular}




\section{CA results Vrysses}

\begin{tabular}{|c|c|c|c|c|c|c|c|c|c|c|c|c|c|c|c|}
\hline fossil taxon & reference taxa & MATmin & MATmax & CMTmin & CMTmax & WMTmin & WMTmax & MAPmin & MAPmax & $\begin{array}{l}\text { MPwet } \\
\text { min }\end{array}$ & $\begin{array}{l}\text { MPwet } \\
\text { max }\end{array}$ & $\begin{array}{l}\text { MPdry } \\
\text { min }\end{array}$ & $\begin{array}{l}\text { MPdry } \\
\max \end{array}$ & $\begin{array}{l}\text { MPwarm } \\
\text { min }\end{array}$ & $\begin{array}{l}\text { MPwarm } \\
\text { max }\end{array}$ \\
\hline Acer pseudomonspessulanum & Acer monspessulanum. & 9.6 & 20.5 & 0.2 & 13.6 & 18.4 & 27.5 & 399 & 1333 & 77 & 191 & 0 & 85 & 0 & 100 \\
\hline Acer sp. & Acer sp............... & -1.1 & 24 & -25.8 & 20.6 & 9.5 & 29.3 & 115 & 10798 & 19 & 2446 & 0 & 135 & 0 & 1100 \\
\hline Buxus pliocaenica & 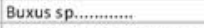 & 9.7 & 25.3 & -1.2 & 20 & 17.3 & 29.4 & 399 & 2540 & 80 & 566 & 0 & 56 & 0 & 252 \\
\hline Poaceae vel Cyperaceae & Poaceae vel Cyperaceae & unspecific & & & & & & & & & & & & & \\
\hline Daphnogene polymorpha & Cinnamomum camphora & 13.5 & 27.2 & 2.5 & 26.1 & 18.6 & 31.7 & 828 & 10798 & 160 & 2446 & 3 & 135 & 30 & 1100 \\
\hline Fabaceae & Fabaceae............. & unspecific & & & & & & & & & & & & & \\
\hline cf. "Juglans" acuminata & unknown............... & & & & & & & & & & & & & & \\
\hline cf. "Parrotia" pristina & Parrotia s.1. ${ }^{*}$ & 11.6 & 27.7 & -4 & 23 & 25.1 & 29.5 & 235 & 3905 & 48 & 610 & 0 & 180 & 0 & 344 \\
\hline Pinus sp. & Pinus sp. & -9.2 & 25.5 & -36.8 & 21.4 & 7.1 & 32.9 & 180 & 10798 & 28 & 2446 & 0 & 94 & 0 & 1100 \\
\hline Populus tremula foss. & Populus tremula..... & -16 & 19 & -49 & 12.2 & 9.8 & 28.3 & 155 & 1958 & 33 & 236 & 2 & 83 & 2 & 141 \\
\hline Quercus sp. & Quercus sp. & -1.4 & 27 & -25.1 & 25.9 & 8.4 & 28.3 & 201 & 10798 & 33 & 2446 & 0 & 180 & 5 & 1100 \\
\hline Quercus mediterranea & Quercus sect. Cerris & 4.7 & 22.2 & -8.7 & 15.6 & 11.7 & 28.6 & 470 & 3000 & 48 & 2695 & 0 & 85 & 0 & 1781 \\
\hline Rosaceae sp. & Rubus, Rosa........... & -12 & 21.7 & -38.8 & 15.2 & 15.3 & 28.2 & 254 & 2100 & 34 & 322 & 4 & 71 & 5 & 269 \\
\hline cf. Salix sp. & Salix sp............... & -17 & 27.7 & -50.1 & 26.5 & 7.6 & 32.9 & 122 & 2399 & 22 & 448 & 0 & 108 & 0 & 252 \\
\hline Tetraclinis sp. & Tetraclinis (articul & relict & & & & & & & & & & & & & \\
\hline Ulmaceae sp. & Ulmaceae............... & -1.2 & 28.5 & -25.8 & 26.7 & 16 & 33.4 & 201 & 3285 & 33 & 454 & 0 & 100 & 0 & 344 \\
\hline \multirow[t]{4}{*}{ cf. Ziziphus ziziphoides } & Ziziphus sp.......... & 7.3 & 27.6 & -12.8 & 26.4 & 14.3 & 35.3 & 304 & 2328 & 45 & 371 & 1 & 43 & 1 & 366 \\
\hline & taxa with climate data & 12 & & & & & & & & & & & & & \\
\hline & coexistence intervals & 13.5 & 19 & 2.5 & 12.2 & 19.3 & 27.5 & 828 & 1333 & 160 & 191 & 4 & 43 & 30 & 100 \\
\hline & coexisting taxa (\%) & & 100 & & 100 & & 100 & & 100 & & 100 & & 100 & & 100 \\
\hline
\end{tabular}

\section{CA results Gavdos}

\begin{tabular}{|c|c|c|c|c|c|c|c|c|c|c|c|c|c|c|c|}
\hline fossil taxon & reference taxa & MATmin & MATmax & CMTmin & CMTmax & WMTmin & WMTmax & MAPmin & MAPmax & $\begin{array}{l}\text { MPwet } \\
\text { min }\end{array}$ & $\begin{array}{l}\text { MPwet } \\
\max \end{array}$ & $\begin{array}{l}\text { MPdry } \\
\text { min }\end{array}$ & $\begin{array}{l}\text { MPdry } \\
\max \end{array}$ & $\begin{array}{l}\text { MPwarm } \\
\text { min }\end{array}$ & $\begin{array}{l}\text { MPwarm } \\
\text { max }\end{array}$ \\
\hline Acer angustilobum & Acer sect. Acer & 2.7 & 24 & -15.6 & 20.6 & 16.2 & 28.6 & 115 & 2559 & 19 & 370 & 1 & 135 & 1 & 366 \\
\hline Ailanthus pythii & Ailanthus sp......... & 6.9 & 26.7 & -8.1 & 25.3 & 18.3 & 28.9 & 376 & 3459 & 92 & 638 & 1. & 119 & 73. & 304 \\
\hline Betula sp. & Betula sp................ & -15 & 25.8 & -41 & 21.1 & 1.3 & 28.7 & 110 & 10798 & 23 & 2446 & 0 & 135 & 2 & 1100 \\
\hline Carpinus sp. & Carpinus sp.......... & 0 & 25.8 & -22.7 & 21.1 & 16.8 & 28.7 & 164 & 10798 & 20 & 2446 & 0 & 130 & 2 & 1100 \\
\hline Daphnogene sp. & Lauraceae.............. & 4.4 & 28.1 & -16.8 & 27 & 19.3 & 30.1 & 191 & 10798 & 56 & 2446 & 0 & 165 & 0 & 1100 \\
\hline Engelhardtia orsbergensis & Engelh.,Oreom.,Alfar & 13.8 & 27.4 & 3.1 & 26.1 & 18.9 & 33.6 & 748 & 10798 & 170 & 2446 & 0 & 152 & 48 & 1100 \\
\hline Fagus gussonii & Fagus sylvatica ssp. orientalis ** & 5.9 & 19.7 & -5 & 9.4 & 17.1 & 31.7 & 376 & 2115 & 46 & 195 & 5 & 94 & 5 & 195 \\
\hline Laurophyllum sp. & Lauraceae............. & 4.4 & 28.1 & -16.8 & 27 & 19.3 & 30.1 & 191 & 10798 & 56 & 2446 & 0 & 165 & 0 & 1100 \\
\hline Leguminosites sp. & Leguminosae.......... & .7 .7 & 27.7 & -22.7 & 25.9 & 10.5 & 28.1 & 224 & 3905 & 46 & 610 & 0 & 196 & 1 & 221 \\
\hline ? Lindera ovata Kolak. & Lauraceae............ & 4.4 & 28.1 & -16.8 & 27 & 19.3 & 30.1 & 191 & 10798 & 56 & 2446 & 0 & 165 & 0 & 1100 \\
\hline Monocotyledonae & monocots.............. & unspecific & & & & & & & & & & & & & \\
\hline Myrica lignitum & Myrica sp.............. & -8.9 & 28.1 & -29 & 27 & 8.9 & 33.9 & 233 & 3151 & 34 & 508 & 0 & 165 & 0 & 221 \\
\hline Paliurus tiliffolius & Paliurus sp........... & 10 & 23.1 & -7.3 & 17 & 22.5 & 28.8 & 396 & 1958 & 68 & 448 & 2 & 70 & 2 & 431 \\
\hline Pinus sp. & Pinus sp................. & -9.2 & 25.5 & -36.8 & 21.4 & 7.1 & 32.9 & 180 & 10798 & 28 & 2446 & 0 & 94 & 0 & 1100 \\
\hline Populus populina & Populus alba......... & 2.5 & 18.5 & -14.6 & 12.5 & 17.9 & 26.4 & 419 & 1741 & 57 & 254 & 1 & 109 & 3 & 80 \\
\hline Salix angusta & & -17 & 27.7 & -50.1 & 26.5 & 7.6 & 32.9 & 122 & 2399 & 22 & 448 & 0 & 108 & 0 & 252 \\
\hline Sapindus graecus & Sapindus sp.......... & 10 & 27.7 & -7.3 & 27 & 20.2 & 32.9 & 184 & 3151 & 22 & 389 & 2 & 165 & 20 & 304 \\
\hline Sassafras sp. & Sassafras sp......... & 9.3 & 22.8 & -3.3 & 14.7 & 21.6 & 30.1 & 843 & 1864 & 71 & 295 & 17 & 93 & 64 & 195 \\
\hline Taxodium dubium & Taxodium sp........... & 13.3 & 25 & -0.1 & 19.8 & 18.9 & 31.2 & 290 & 2615 & 60 & 265 & 0 & 93 & 19 & 227 \\
\hline Tetraclinis salicornoides & Tetraclinis farticul & relict & & & & & & & & & & & & & \\
\hline \multirow[t]{4}{*}{ Ulmus (?) plurinervia } & Ulmus sp............ & -4.9 & 26.6 & -25.8 & 26.1 & 16 & 29.4 & 201 & 3285 & 33 & 569 & 0 & 100 & 0 & 239 \\
\hline & taxa with climate data & 19 & & & & & & & & & & & & & \\
\hline & coexistence intervals & 13.8 & 18.5 & 3.1 & 9.4 & 22.5 & 26.4 & 843 & 1741 & 170 & 195 & 17 & 70 & 73 & 80 \\
\hline & coexisting taxa (\%) & & 100 & & 100 & & 100 & & 100 & & 100 & & 100 & & 100 \\
\hline
\end{tabular}

\footnotetext{
* data set for Fothergilleae

** data set for European Fagus
} 
